\title{
Specification
}

Project No. 33547-802650

\section{Uranium Prototype Glovebox and Furnace Design and Build}

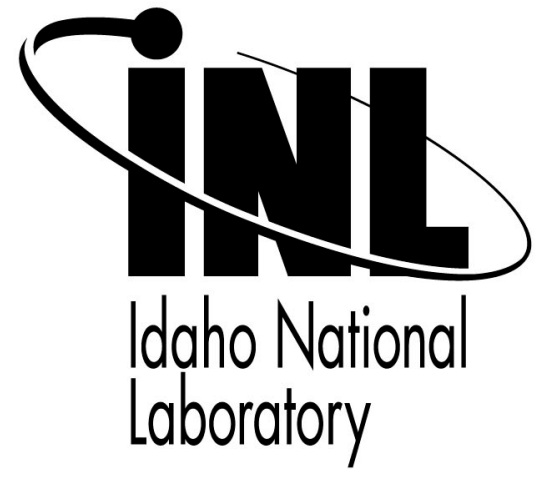

The INL is a U.S. Department of Energy National Laboratory operated by Battelle Energy Alliance. 
INTENTIONALLY BLANK 


\begin{tabular}{|l|lll|}
\hline URANIUM PROTOTYPE GLOVEBOX & Identifier: & SPC-2954 & \\
AND FURNACE DESIGN AND BUILD & Revision: & 0 & \\
& Effective Date: & $01 / 19 / 21$ & Page: 1 of 50 \\
\hline
\end{tabular}

\begin{tabular}{|l|l|}
\hline Materials and Fuels Complex & Specification \\
\hline
\end{tabular}

Manual: Stand Alone

\section{CONTENTS}

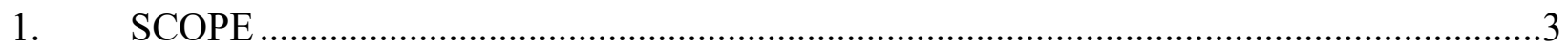

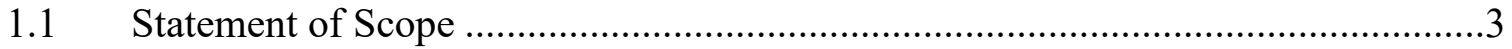

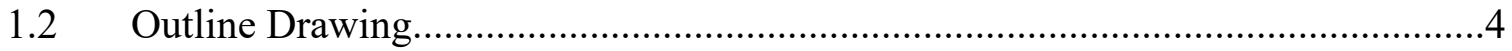

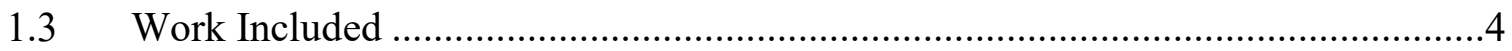

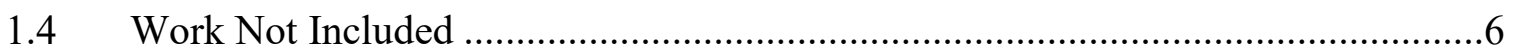

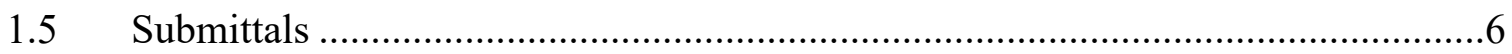

2. APPLICABLE CODES, STANDARDS, AND REFERENCES …………......................

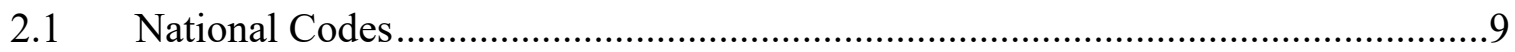

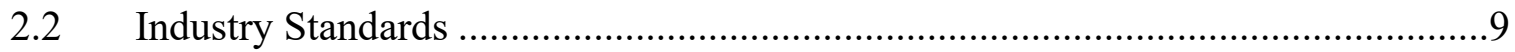

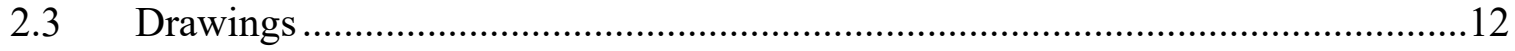

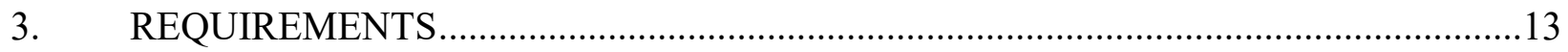

3.1 General Design Requirements .......................................................................13

3.2 General Material Requirements ......................................................................16

3.3 Design Features.............................................................................................17

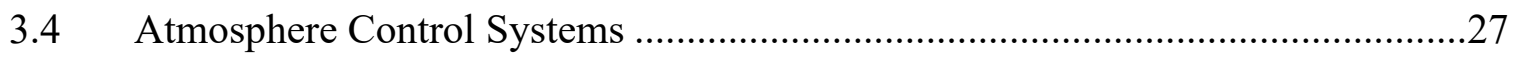

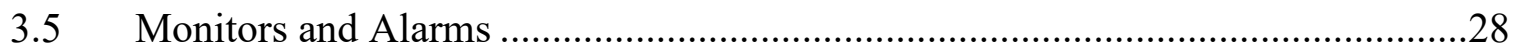

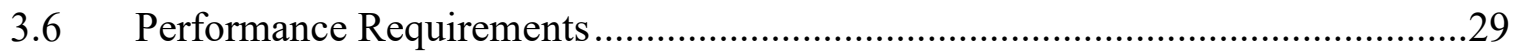

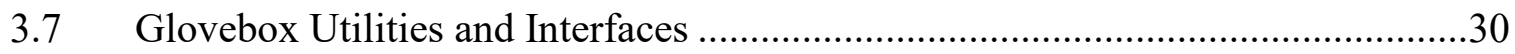

3.8 Drawing and Configuration Control Requirements ..................................................31

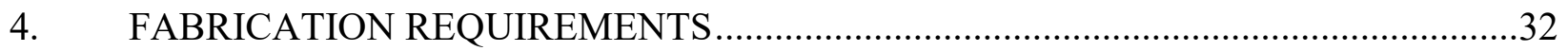

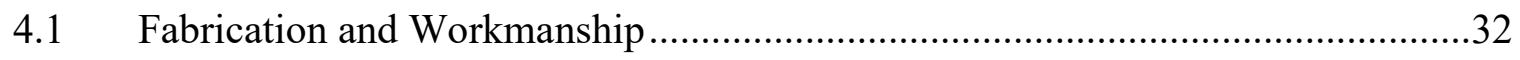

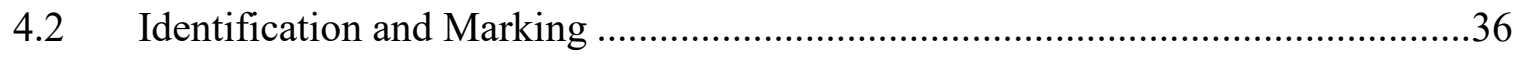

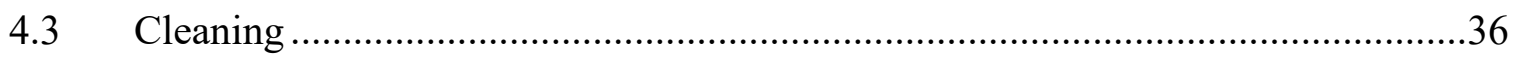




\begin{tabular}{l|lll|} 
URANIUM PROTOTYPE GLOVEBOX & Identifier: & SPC-2954 & \\
AND FURNACE DESIGN AND BUILD & Revision: & 0 & \\
& Effective Date: & $01 / 19 / 21$ & Page: 2 of 50 \\
\hline
\end{tabular}

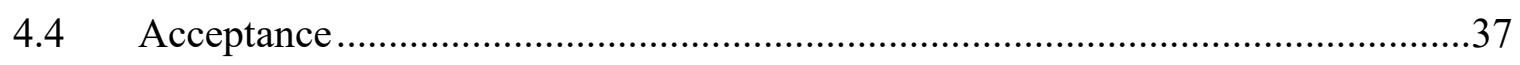

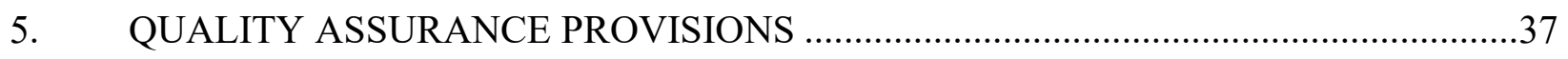

5.1 Standard INL Quality Assurance Requirements ........................................... 37

5.2 Fabrication/Assembly Inspections, Tests and Hold Points.................................39

5.3 Post Assembly Inspections, Tests and Hold Points .......................................40

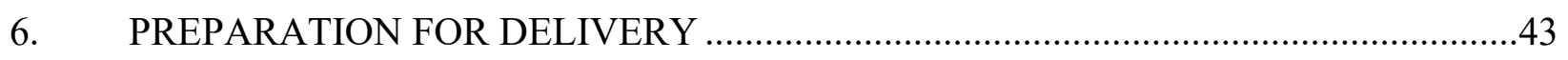

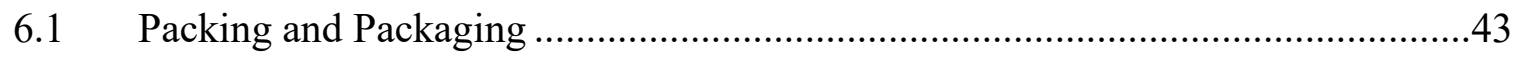

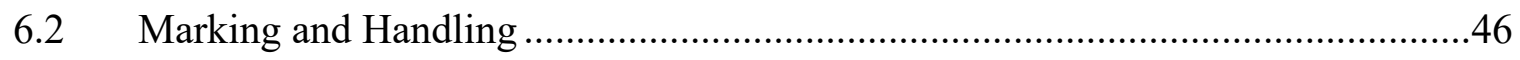

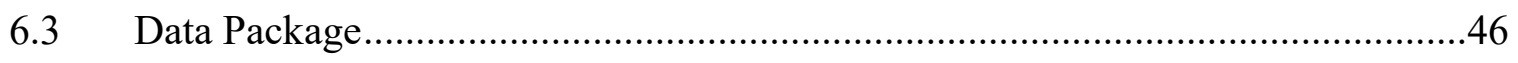

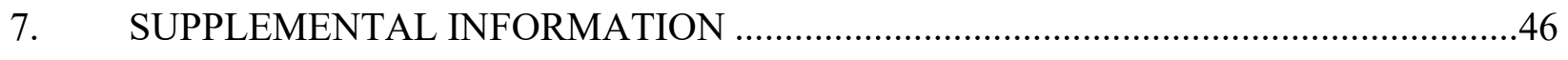

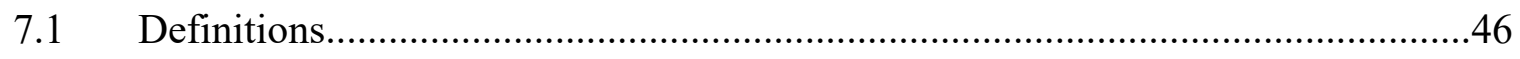

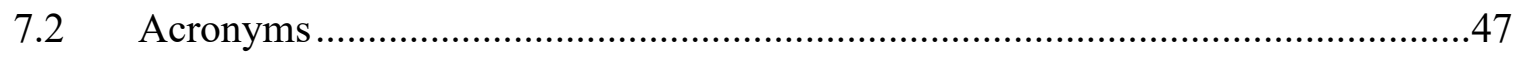

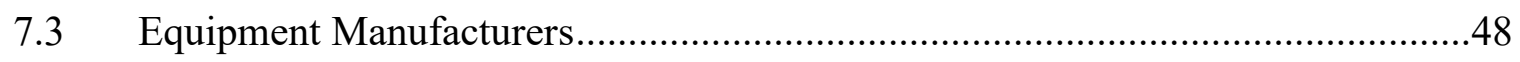

Appendix A Parts List for the Uranium Prototype Glovebox......................................A1

Appendix B Casting Furnace Design................................................................... B1 


\begin{tabular}{|l|lll|}
\hline URANIUM PROTOTYPE GLOVEBOX & Identifier: & SPC-2954 & \\
AND FURNACE DESIGN AND BUILD & Revision: & 0 & \\
& Effective Date: & $01 / 19 / 21$ & Page: 3 of 50 \\
\hline
\end{tabular}

\section{SCOPE}

\subsection{Statement of Scope}

This specification contains the requirements for design, analysis, fabrication, testing and delivery of the Uranium Prototype Glovebox (UPG) and Furnace, and the associated equipment as described herein. The UPG will be primarily used for the containment of uranium and the prototyping of equipment to be used in higher hazard category gloveboxes. This will allow complex pieces of equipment to be tested in a less hazardous environment prior to fabrication and installation in other gloveboxes.

Prior to shipment, the glovebox and furnace will be fabricated, assembled, and tested at the fabricator's facility. After successful completion of acceptance testing, the glovebox and associated equipment will be shipped to the Materials and Fuels Complex (MFC) at the Idaho National Laboratory (INL) to be installed by others in a location yet to be determined. The completed glovebox assembly will be modular (sectional) in design, allowing the glovebox line to be transported via existing doors into its final location for reassembly and installation.

The glovebox assembly will consist of a furnace installed in a glovebox, supported by an airlock which can be connected to a hood or other glovebox. The fuel casting system includes an induction furnace installed in a well in the floor of the glovebox with associated power supply, an argon accumulation system, an additional vacuum pump, and a pallet transfer system that will be used to cast prototypical fuel pins. The glovebox will be double-sided containing an inert atmosphere of argon gas. This specification contains the requirements for the glovebox, airlock, pressure controls, atmosphere purification systems, and the fuel casting system. The fuel casting system description and requirements are included in Appendix B. Interfaces are defined between the glovebox and periphery equipment including the facility utility systems and glovebox penetrations to support additional process equipment that will be installed in the glovebox (by others) after delivery. 


\begin{tabular}{l|lll|} 
URANIUM PROTOTYPE GLOVEBOX & Identifier: & SPC-2954 & \\
AND FURNACE DESIGN AND BUILD & Revision: & 0 & \\
& Effective Date: & $01 / 19 / 21$ & Page: 4 of 50 \\
\hline
\end{tabular}

\subsection{Outline Drawing}

The glovebox concept is shown below in Figure 1. The configuration of the gloveboxes, nominal dimensions, and pertinent system interface locations and details are shown on INL drawing 1003370.

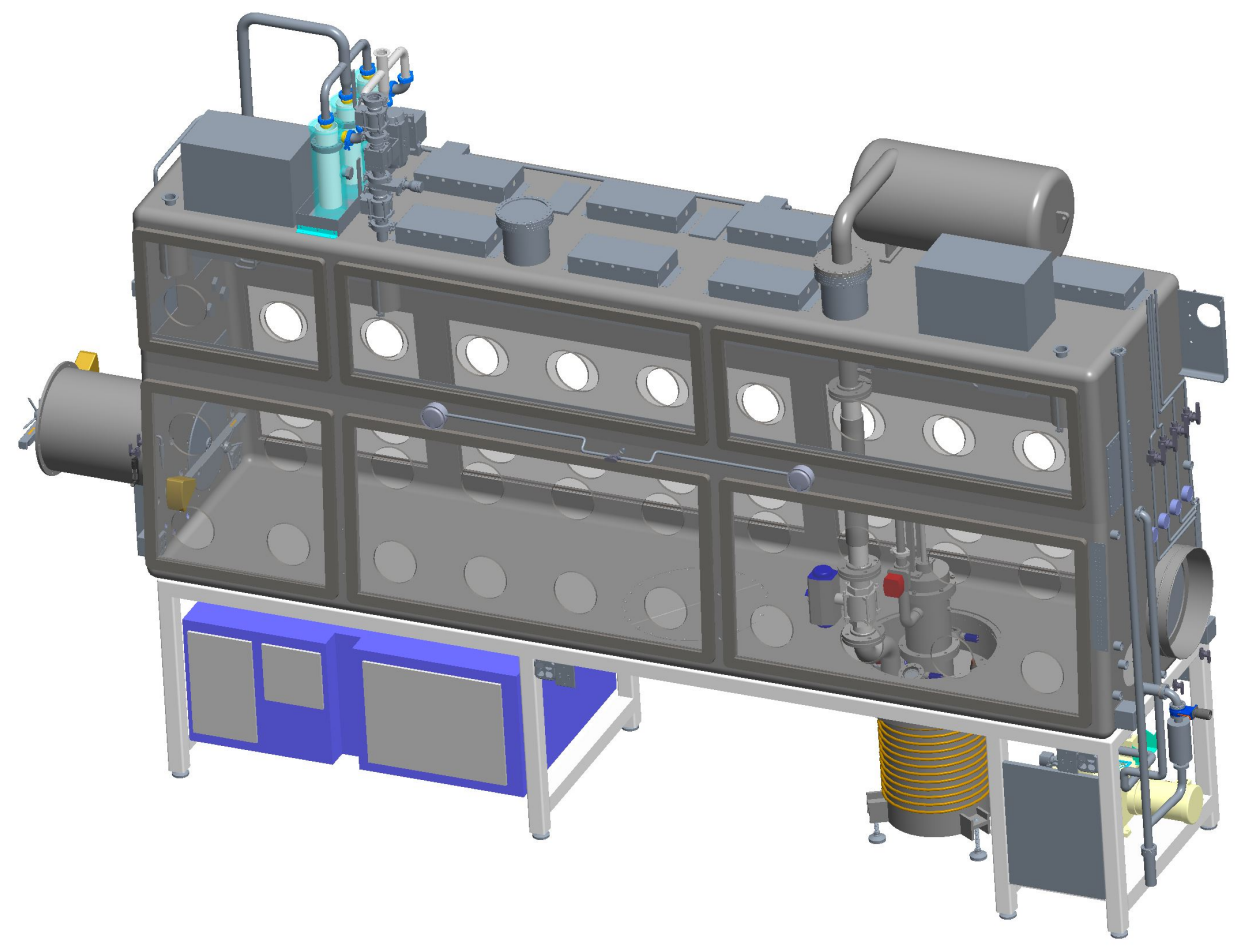

Figure 1. UPG and Casting System

\subsection{Work Included}

The subcontractor shall provide all labor, material, equipment, and services necessary to design, fabricate, assemble, test, disassemble, prepare for shipment, and deliver the glovebox and casting system complete and in accordance with this specification and the applicable contract drawings, subject to terms and conditions of the contract or purchase order. The work includes, but is not limited to the following:

A. Design, fabrication, procurement, and assembly of the glovebox, with the associated pressure control systems, electrical system, and atmosphere purification systems

1. Government furnished equipment (GFE) will be provided by INL as identified in the contract "Schedule-X" and summarized below:

a) Purification systems (includes atmosphere analyzers, coolers, secondary valve, exhaust stacks) 
URANIUM PROTOTYPE GLOVEBOX AND FURNACE DESIGN AND BUILD

\begin{tabular}{|lll|} 
Identifier: & SPC-2954 & \\
Revision: & 0 & \\
Effective Date: & $01 / 19 / 21$ & Page: 5 of 50 \\
\hline
\end{tabular}
b) One bubbler assembly
c) Gloveports and bagports with 15-in change tool
d) Airlock

B. Assembly and integrated factory acceptance testing of the glovebox and casting system at the subcontractor's glovebox test facility

C. Design and fabrication of the structural frame, enclosures, and appurtenances

D. Sublet design and fabrication of the casting system to Ajax TOCCO Magnethermic Corporation to include the furnace, power supply, and associated equipment to perform complete casting capability

E. Integration of the casting system with the glovebox

F. Integration of the airlock with the glovebox

G. Design, procurement, and installation of glovebox internal and external power distribution in accordance with the specifications herein

H. Design, procurement, fabrication, and installation of windows, gaskets, and mounting hardware

I. Procurement and external mounting of lighting and control equipment for lighting the interior of the glovebox

J. Installation of gloveports, bagports, and associated hardware

K. Procurement or fabrication and installation of glovebox penetrations, feedthroughs, or connection points as specified

L. Procurement and installation of the hardware to support a heat detection system

M. Installation of atmosphere monitors

N. Fabrication and installation of hoist in accordance with the listed drawings

O. Fabrication and installation of brackets for radiation monitoring equipment

P. Design and construction of support equipment at the subcontractor's facility to permit assembly, inspection, and testing as specified herein

Q. Preparation of analyses (fully documented) and independent peer review of analysis to support seismic criteria as specified herein 
URANIUM PROTOTYPE GLOVEBOX AND FURNACE DESIGN AND BUILD

\begin{tabular}{|lll|} 
Identifier: & SPC-2954 & \\
Revision: & 0 & \\
Effective Date: & $01 / 19 / 21$ & Page: 6 of 50 \\
\hline
\end{tabular}

R. Preparation and submittal of complete detailed fabrication drawings for the glovebox, casting system, and all details

S. Preparation and submittal of electrical wiring diagrams and schematic drawings

T. Preparation and submittal of inspection and test documentation, and performance of all testing and inspections as specified herein

U. Preparation and submittal of various, drawings, inspection or test documentation, certifications, schedules, and assembly instructions as required by this specification or as otherwise required by contract or purchase order

V. Provision of all crates, skids, protective devices, lifting lugs, and materials used for shipping and handling between the fabrication facilities and INL

W. Disassembly, shipping, and delivery of the glovebox and casting system and associated hardware to INL

\subsection{Work Not Included}

Final installation of the glovebox, casting system, and integration with INL facility systems will be the responsibility of INL and, as such, is not within the scope of this specification. INL assumes all responsibility for integration and testing associated with the following:

A. Final in-place installation at INL site, including reassembly of glovebox, associated atmosphere control equipment, and casting system

B. Final interconnection of the glovebox electrical, atmosphere control, and monitoring system alarms to the facility electrical, ventilation, and utility systems

C. Installation of gloves in the glove rings

D. Connection and integration of the heat detection equipment to the facility alarm system

\subsection{Submittals}

1.5.1 Vendor Proposal. Subcontractor shall provide split out cost information for the glovebox windows, hoist, furnace with power supply, and analysis services. The following milestone payment schedule is planned. Subcontractor shall provide a breakdown of contract total cost into these milestones:

- $\quad$ Glovebox Design (including analysis) 


\begin{tabular}{l|lll|} 
URANIUM PROTOTYPE GLOVEBOX & Identifier: & SPC-2954 \\
AND FURNACE DESIGN AND BUILD & Revision: & 0 & \\
& Effective Date: & $01 / 19 / 21$ & Page: 7 of 50 \\
\hline
\end{tabular}

- $\quad$ Casting System Design (including analysis)

- $\quad$ Long Lead material requisitions

- Fabrication

- $\quad$ Testing

- Delivery.

1.5.2 Vendor Data Schedule. Subcontractor and sub tier supplier data shall be submitted in accordance with the Vendor Data Schedule.

The subcontractor shall use the INL Electronic Vendor Data System for processing all vendor data for this project. Vendor data shall be electronically transmitted to the Vendor Data Coordinator (Angela Perkins, Angela.Perkins@inl.gov) for processing using the INL Vendor Data Transmittal and Disposition form 431.13.

Where submittals require approval or concurrence, INL will return such concurrence or corrections or comments to the subcontractor within five (5) working days after receipt of submittal. Where corrections are required, the subcontractor shall submit corrected drawings, analysis, and so forth, until approval is granted by the laboratory. It is not the intent of INL to be obstructive, in reviewing data submittals, but to simply ensure compliance with the intent and requirements of this specification.

INL approval of drawings or analyses does not imply that INL accepts any responsibility for errors that may result in component reworks, schedule delays, or increased fabrication costs.

1.5.3 Design and Fabrication Schedule. The subcontractor shall provide a design and fabrication schedule identifying all design and fabrication steps, key inspections or tests, and hold points. The initial schedule shall be provided to INL with the subcontractor's proposal in accordance with the Vendor Data Schedule.

The subcontractor shall provide a schedule of values that directly correlates to the activities on the design and fabrication schedule that will be used to calculate earned value as a basis for monthly progress and vendor billing. The schedule and assigned values shall be at a level of detail to allow for Earned Value Management (EVM) on the work such that the amount of work performed can be compared to and quantified based on the amount of work planned (in the schedule), and the cost of work performed can be compared to and quantified based on the amount of work planned. To facilitate a reasonable level of accuracy, the level of 
URANIUM PROTOTYPE GLOVEBOX AND FURNACE DESIGN AND BUILD

\begin{tabular}{|lll|} 
Identifier: & SPC-2954 & \\
Revision: & 0 & \\
Effective Date: & $01 / 19 / 21$ & Page: 8 of 50 \\
\hline
\end{tabular}

detail for activity breakdown and durations of those activities shall not exceed 2-4 weeks, where at all possible. The cumulative planned cost for all scheduled activities shall total to the amount of the subcontract. The initial schedule of values shall be provided to INL with the subcontractor's proposal in accordance with the Vendor Data Schedule

The subcontractor also shall provide, for INL approval, a revised schedule within seven (7) working days of any modification to the subcontract that revises the scheduled delivery date or when other approved laboratory changes affect a scheduled assembly step, hold point, test, or inspection.

1.5.4 Subtier Services Plan. The subcontractor shall provide a subtier services plan that includes the name, address, telephone number, and point of contact for all outside services that the subcontractor intends to use to perform any portion of the work required by this specification. This plan also shall identify the specific work requirements of this specification that will be performed by those outside services. The subcontractor shall submit this plan in accordance with the Vendor Data Schedule.

1.5.5 Project Updates. A conference call shall be held weekly to provide a project update. The purpose of this phone call will be to address any concerns or questions with the project and provide an informal status report.

1.5.6 Status Reports. Written status reports shall be submitted to the Laboratory's project manager by the subcontractor on a monthly basis with the report due by the 15 th day of each month. The report shall include a narrative progress summary describing accomplishments and any areas of concern in addition to the status of the design and fabrication schedule. In addition, the status reports shall include a status of Earned Value in accordance with the schedule from paragraph 0.

1.5.7 Design Presentations. The subcontractor shall provide preliminary and final design presentations to INL. Preliminary design shall be approved by INL prior to proceeding with final design. A final design presentation is required prior to final design approval and proceeding with fabrication. The presentation shall be led by the subcontractor and shall include, at a minimum, the subcontractor's lead engineer, and the lead analysis engineer. The preliminary design presentation will be performed at the design agency's facility. The final design presentation shall be performed at INL. Subcontractor personal may participate in the final design presentation by video link. 


\begin{tabular}{l|lll|} 
URANIUM PROTOTYPE GLOVEBOX & Identifier: & SPC-2954 & \\
AND FURNACE DESIGN AND BUILD & Revision: & 0 & \\
& Effective Date: & $01 / 19 / 21$ & Page: 9 of 50 \\
\hline
\end{tabular}

\section{APPLICABLE CODES, STANDARDS, AND REFERENCES}

The following documents form a part of this specification to the extent specified herein. Unless otherwise specified, the issue in effect on the date of invitation to bid shall apply. In the event of a conflict between the documents referenced herein and the contents of this specification, the subcontractor should notify INL; however, in general the contents of this specification shall be considered a superseding requirement.

\subsection{National Codes}

National Fire Protection Association (NFPA)

NFPA $70 \quad$ National Electrical Code (NEC)

NFPA $86 \quad$ Standard for Ovens and Furnaces

NFPA 801 Fire Protection for Facilities Handling Radiological Materials

\subsection{Industry Standards}

American Glovebox Society (AGS)

AGS-G001-2007 Guidelines for Glovebox, Third Edition

AGS-G006-2005 Standard of Practice for the Design and Fabrication of Nuclear-Application Glovebox

American National Standards Institute (ANSI)

ANSI /ISO Q9001 Quality Management System Requirements (or equivalent quality program for non-Nuclear Safety items)

ANSI Y14.5 Dimensioning and Tolerancing for Engineering Drawings

American Society of Civil Engineers (ASCE)

ASCE-07-10 Minimum Design Loads for Buildings and Other Structures

American Society for Nondestructive Testing Inc. (ASNT)

ASNT-TC-1A Recommended Practice for Personal Qualification and Certification in Nondestructive Testing

American Society of Mechanical Engineers (ASME)

ASME BPVC.V ASME Boiler and Pressure Vessel Code, Section V:

Nondestructive Examination 
URANIUM PROTOTYPE GLOVEBOX AND FURNACE DESIGN AND BUILD

$\begin{array}{lll}\text { Identifier: } & \text { SPC-2954 } \\ \text { Revision: } & 0 \\ \text { Effective Date: } & 01 / 19 / 21\end{array}$

Page: 10 of 50

ASME BPVC.VIII ASME Boiler and Pressure Vessel Code, Section VIII:

Pressure Vessels

ASME B30.2

Overhead and Gantry Cranes (Top Running Bridge, Single or Multiple Girder, Top Running Trolley Hoist)

ASME B30.10

Hooks Safety Standard for Cableways, Cranes, Derricks, Hoists, Hooks, Jacks, and Slings

ASME B30.16

Overhead Hoists (Underhung)

ASME B30.17

Cranes and Monorails (With Underhung Trolley or Bridge)

ASME B31.3

Process Piping

ASME B31.9

Building Services Piping

ASME HST-4

Performance Standard for Overhead Electric Wire Rope Hoists

American Society of Testing and Materials (ASTM)

ASTM A36

ASTM A167

ASTM A240

ASTM A276

ASTM A370

ASTM A380

ASTM A480

ASTM A500

ASTM A511
Standard Specification for Carbon Structural Steel

Standard Specification for Stainless and Heat-Resisting

Chromium-Nickel Steel Plate, Sheet, and Strip

Standard Specification for Heat-Resisting Chromium and Chromium-Nickel Stainless Steel Plate, Sheet, and Strip for Pressure Vessels

Standard Specification for Stainless and Heat- Resisting Steel Bars and Shapes

Standard Test Methods and Definitions for Mechanical Testing of Steel Products

Cleaning and Descaling Stainless Steel Parts, Equipment, and Systems

Standard Specification for Flat-Rolled Stainless and Heat-Resisting Steel Plate, Sheet, and Strip

Standard Specification for Cold-Formed Welded and Seamless Carbon Steel Structural tubing in Rounds and Shapes

Standard Specification for Stainless Steel Mechanical Tubing 
URANIUM PROTOTYPE GLOVEBOX AND FURNACE DESIGN AND BUILD

$\begin{array}{ll}\text { Identifier: } & \text { SPC-2954 } \\ \text { Revision: } & 0 \\ \text { Effective Date: } & 01 / 19 / 21\end{array}$

ASTM A554

ASTM C162

ASTM C1036

ASTM C1048

ASTM C1172

ASTM D2000

ASTM E499
Standard Specification for Welded Stainless Steel Mechanical Tubing

Standard Definitions of Terms Relating to Glass and Glass Products

Standard Specification for Flat Glass

Standard Specification for Heat-Treated Flat Glass - Kind HS, Kind FT Coated and Uncoated Glass

Standard Specification for Laminated Architectural Flat Glass

Classification System for Rubber Products in Automotive Applications

Standard Practice for Leaks Using the Mass Spectrometer Leak Detector in the Detector Probe Mode

American Welding Society (AWS)

AWS A2.4

Standard Symbols for Welding, Brazing, and

Nondestructive Examination

AWS B2.1

Specification for Welding Procedure and Performance Qualification

AWS D1.1

Structural Welding Code - Steel

AWS D1.6

Structural Welding Code - Stainless Steel

Department of Energy (DOE)

DOE-STD-1020-2016Natural Phenomena Hazards Design and Evaluation Criteria for Department of Energy Facilities

DOE-STD- $1090 \quad$ Hoisting and Rigging Manual

International Electrotechnical Commission (IEC)

ISO/IEC 17025 General requirements for the competence of testing and calibration laboratories

$\underline{\text { Idaho National Laboratory (INL) }}$

INL-STD-139-26 $0001 \quad$ Electrical Component Marking, INL Engineering Standards 


\begin{tabular}{l|lll|} 
URANIUM PROTOTYPE GLOVEBOX & Identifier: & SPC-2954 & \\
AND FURNACE DESIGN AND BUILD & Revision: & 0 & \\
& Effective Date: & $01 / 19 / 21$ & Page: 12 of 50 \\
\hline
\end{tabular}

\subsection{Drawings}

$\underline{\text { Central Research Laboratories (CRL) }}^{\mathrm{a}}$

42686 SST Enclosure Ring Assembly (8-in round)

42690 Enclosure Ring Gasket Kit, Viton (8-in round)

38996 Plug Assembly, Viton O-ring (8-inch round)

$17474 \quad$ Locking Ring (8-inch round)

37969 SST Enclosure Ring, Weld-in (8-inch round)

$50580 \quad$ SST Enclosure Ring, Weld-in (15-inch round) with seal O-ring (CRL 7-96184).

34377 Locking Ring (15-inch round)

42659 Plug Assembly, Neoprene O-ring (15-in round)

Flanders Filters Inc. ${ }^{\mathrm{b}}$

0-007-1-43-RF-NU-51-E3-Z11410 5-in diameter x 6-3/4-in radial flow filter

0-007-1-43-RF-NU-51-E3-Z14239 5-in diameter x 12-in radial flow filter

Idaho National Laboratory (INL)

853554 MFC Glovebox Heat Detection Thermoswitch Protective

Well Assembly Glovebox Penetration and Support

Hardware

$1003370 \quad$ Glovebox Layout for Uranium Prototype Glovebox and

Casting System

Sketch DSJ-014 Uranium Prototype Glovebox P\&ID

a. Central Research Laboratories, 3965 Pepin Avenue, Red Wing, Minnesota USA 55066

Tel: (651) 385-2142, Fax: (651) 385-2109, www.centres.com/index.htm

b. Flanders Filters, Inc., 531 Flanders Filters Road, Washington, North Carolina 27889

Tel.: 252-946-8081, Fax: 252-946-3425, http://www.flanders-csc.com 


\begin{tabular}{|l|lll|} 
URANIUM PROTOTYPE GLOVEBOX & Identifier: & SPC-2954 & \\
AND FURNACE DESIGN AND BUILD & Revision: & 0 & \\
& Effective Date: & $01 / 19 / 21$ & Page: 13 of 50 \\
\hline
\end{tabular}

$\underline{\text { M Braun, Inc. }}{ }^{\mathrm{c}}$

8015676 3-Bubbler Safety Bubbler Assembly, \pm 15 mBar

TBD R390 Antechamber assembly (700mm long)

$8026174 \quad$ Antechamber control panel

$8041721 \quad$ L450 Chamber Door assembly

TBD Exhaust Stack

\section{REQUIREMENTS}

\subsection{General Design Requirements}

The Uranium Prototype Glovebox and Casting System shall be designed in accordance with the requirements listed within this document. The glovebox shall be designed to conform to the nominal dimensional outline shown on the drawings listed in Section 2.3.

AGS-G001-2007 shall be used as a guide for the design and fabrication of these gloveboxes. AGS-G006-2005 shall be used when specifically invoked in this specification.

\subsubsection{Modular Design}

The complete assembly consisting of the support frame and the associated glovebox shall be a bolt together design. The completed assembly shall be designed to minimize disassembly for shipment and installation in accordance with these specifications:

3.1.1.1 The design shall be based on the approximate profile shown on the drawings.

3.1.1.2 The glovebox shell shall be a single weldment bolted to its support frame.

3.1.1.3 The glovebox shell and structural support frame shall include lift points for lifting each component separately. If required, lift points for moving the completely assembled glovebox and stand shall also be provided.

c. MBraun Inc., 14 Marin Way, Stratham, New Hampshire, 03858

Tel: 603-773-9333, Fax: 603-773-0008, www.mbraunusa.com 
URANIUM PROTOTYPE GLOVEBOX AND FURNACE DESIGN AND BUILD

\begin{tabular}{|lll|} 
Identifier: & SPC-2954 & \\
Revision: & 0 & \\
Effective Date: & $01 / 19 / 21$ & Page: 14 of 50 \\
\hline
\end{tabular}

3.1.1.4 The glovebox airlock and furnace well shall be bolt-together construction to facilitate disassembly as shown on the drawings. The airlock shall remain connected to the glovebox for shipment.

3.1.1.5 The glovebox should be shipped with windows, gaskets, and frames installed. Gloveport assemblies (complete with plugs and locking rings) shall remain installed in the windows.

3.1.1.6 Atmosphere pressure control, purification, and atmosphere monitoring equipment shall remain connected for shipment if possible. The subcontractor should consider locating optimal disassembly joints so that most equipment, valves and piping can remain connected to the glovebox shell or stand during transfer into the facility.

3.1.1.7 Ductwork or piping that must be removed for shipping or transport into the facility should be easily removed and replaced. Compression or swage-type connections are preferred for pressurized lines. Kwik Flange (KF)-style or VCR flanged connections are preferred for connections that will operate near atmospheric or sub-atmospheric pressure. (Refer to paragraph 7.3 and the P\&ID listed in paragraph 2.3.)

3.1.1.8 Switches, junction boxes, and lighting/power panels should remain installed in-place to the extent possible. Junction boxes shall be provided where practical and where electrical conduits must be removed or disconnected.

\subsubsection{Design for Installation}

3.1.2.1 Piping or ductwork used for inert or regeneration gas systems shall be flanged and welded stainless steel tubing.

3.1.2.2 The number of connections and break-points should be minimized. Compression or flare-type fittings shall not be used for glovebox piping/tubing connections which will operate at near or sub-atmospheric pressure without the approval of the INL. Kwik Flange (KF), Conflat (CF), or VCR flanged joints are preferred. Tube and fittings used to connect equipment shall be selected in fractional inch units. National pipe thread (NPT) joints should be minimized. (Connections and joints internal to subtier or vendorsupplied equipment are excluded from this requirement.) 
URANIUM PROTOTYPE GLOVEBOX AND FURNACE DESIGN AND BUILD

\begin{tabular}{|lll|} 
Identifier: & SPC-2954 & \\
Revision: & 0 & \\
Effective Date: & $01 / 19 / 21$ & Page: 15 of 50 \\
\hline
\end{tabular}

3.1.2.3 Electrical loads, not including the furnace, shall utilize 208 VAC/120VAC, single phase, or 208 VAC three phase, and shall be prewired to lighting/power panels supplied by the subcontractor and attached to each support frame as shown on the drawings.

3.1.2.4 Except for connections to the pressure relief bubblers, and secondary vent, connection points shall be provided for all facility utilities (electrical, gas supplies and exhausts) at a single location for the glovebox and the purifier as shown on the drawings.

3.1.2.5 The subcontractor is free to select alternative materials or construction techniques for mock-up or use at their facility insofar as such materials or construction techniques support successful completion of the inspections and testing listed herein and insofar as such materials or construction techniques do not permanently affect the completed glovebox line or associated systems. After completion of the inspections and tests specified herein, disposition of any temporary support equipment is at the discretion of the subcontractor.

\subsubsection{Design for Maintainability}

3.1.3.1 The glovebox/support frame assembly and various tubing routes shall be designed and fabricated to permit access to and removal of the power supply and future furnace as well as their associated access panels.

\subsubsection{Standardization}

3.1.4.1 In an effort to standardize features and components used in gloveboxes at MFC, INL has identified preferred parts for certain components. Where this specification refers to a manufacturer part number, the subcontractor shall verify the part is adequate for its intended use. In some cases, specific equipment models have been identified in this specification because INL already has programs in-place for performing maintenance and has spare/replacement parts available for such equipment. The naming of a manufacturer in this specification or on the contract drawing(s) shall eliminate product substitution by other manufacturers having equivalent products (unless specifically identified with "or equivalent" notation). Identification of specific equipment does not imply that alternative equipment may not be considered where a real benefit to the Laboratory can be 


\begin{tabular}{l|lll|} 
URANIUM PROTOTYPE GLOVEBOX & Identifier: & SPC-2954 & \\
AND FURNACE DESIGN AND BUILD & Revision: & 0 & \\
& Effective Date: & $01 / 19 / 21$ & Page: 16 of 50 \\
\hline
\end{tabular}

shown, however, INL approval is required to use alternate equipment.

\subsection{General Material Requirements}

3.2.1 All hardware items such as fasteners, studs, bolts, nuts, machine screws, hinges, or like components used in the fabrication of the glovebox or associated appurtenances or equipment shall be stainless steel (SST). Alternative materials may be proposed by the design agent where stainless steel is not a suitable option. This requirement excludes fasteners associated with vendor supplied equipment such as fasteners on lights, analyzers, and electrical housings. Where such use is not practical or feasible, standard commercial finish as supplied by sub-tier suppliers may be used provided such items are free of corrosion, pitting, or handling damage.

3.2.2 Where SST parts are to be threaded together, dissimilar grades of stainless steel shall be used to reduce the potential for galling. (e.g., Nitronic ${ }^{\circledR}$ 60, type 17-4 PH; Note: using two different 300 series does not meet this requirement.) This requirement applies to all threaded connections on the shell and airlock. For example, nuts, bolts, weld studs, pipe couplings, valves, penetrations, etc. Use of thread inserts is prohibited.

3.2.3 For mounting windows to the glovebox shell:

- $\quad$ Male studs should be minimum 1/4"-20 thread and dissimilar material to enable using common 300 series acorn nuts

- $\quad$ Female Studs (tapped pad or weld standoff) should be dissimilar material to enable using minimum $1 / 4$ "-20 thread, common 300 series button machine screws

- $\quad$ Thick flange window frames should be dissimilar material with tapped holes to enable using common 300 series screws such as cap or button head machine screws.

3.2.4 For pipe threaded connections, the pipe fittings welded to the shell shall be dissimilar material to 300 series stainless steel such that standard 300 series pipe plugs, caps, and other fittings may be threaded to the shell.

3.2.5 Use of multi-strand steel cable or rope is prohibited. 


\begin{tabular}{l|lll|} 
URANIUM PROTOTYPE GLOVEBOX & Identifier: & SPC-2954 & \\
AND FURNACE DESIGN AND BUILD & Revision: & 0 & \\
& Effective Date: & $01 / 19 / 21$ & Page: 17 of 50 \\
\hline
\end{tabular}

\subsection{Design Features}

\subsubsection{Glovebox Support Frame}

3.3.1.1 The subcontractor is responsible for designing and providing a support structure or frame for the glovebox within the dimensional limits shown on the drawings and as specified herein.

3.3.1.2 The structural frame may be fabricated from either rectangular stainless steel tubing meeting the requirements of ASTM A511 or A554 or rectangular steel tubing meeting the requirements of ASTM A500.

3.3.1.3 Structural bars and shapes shall meet the requirements of ASTM A36 or ASTM A276. Stainless steel structural material should be the same type of stainless steel as the enclosure shell if possible. Where plate stock is required for use as reinforcement or for mounting pads, it shall be of the same type of material as the glovebox frame material.

3.3.1.4 The size (preferably 2.0 -in $\mathrm{x}$ 0.25-in square tube) and number of frame members shall be minimized while meeting the requirements of Section 3.3.1.7.

3.3.1.5 Support frame legs shall be equipped with leveling pads and separate anchoring pads to accommodate $\mathrm{a} \pm 1$-inch variation in the facility floor elevation.

3.3.1.6 Anchoring pads with at least 24-square inches floor contact area shall be offset to the inside of the glovebox footprint to avoid tripping hazards.

3.3.1.7 Support frames, mounting pads, and anchorage shall be designed to meet the natural phenomena requirements in Section 3.6.5. The mounting pads under the structural support frame shall be provided without tie-down holes. The holes will be field drilled based on allowable drilling locations.

\subsubsection{Glovebox Shell}

3.3.2.1 The shell shall be constructed to maximize the interior volume of the glovebox and to minimize intrusion of any joints or load-bearing members into the useable interior space. 
URANIUM PROTOTYPE GLOVEBOX AND FURNACE DESIGN AND BUILD

\begin{tabular}{|lll|} 
Identifier: & SPC-2954 & \\
Revision: & 0 & \\
Effective Date: & $01 / 19 / 21$ & Page: 18 of 50 \\
\hline
\end{tabular}

3.3.2.2 The shell and deck shall be fabricated from stainless steel per ASTM A240 or A480.

3.3.2.3 Shell thickness shall be a minimum of 7 gauge, unless otherwise noted on the drawings.

3.3.2.4 The glovebox floor shall be constructed of minimum 3/8-in thick plate. The floor plate shall be a single seamless piece of material.

3.3.2.5 The stainless steel shell and floor material shall be either No. 4 mill finish, or ASTM A480 2B finish. A 32 microinch surface finish or better shall be provided for all sealing surfaces and uniformly across entire internal surfaces.

3.3.2.6 Weld joints in the shell shall be full penetration welded except the shell/floor interface joints. Shell floor interface welding should be in accordance with sketch AGS009 Option 2 in AGS-G001-2007 except exterior fillet weld should be 1-6-inch skip weld or more frequent as determined by seismic analysis.

3.3.2.7 The glovebox shell shall incorporate rounded corners between 5/8-in and 1.0-in radius to accommodate decontamination. End panels shall be welded.

3.3.2.8 The glovebox shells shall incorporate mounting locations for casters to move shells into the facility at INL. Casters shall be provided by subcontractor and adjustable up to 2-in. Overall height of completed shell with casters installed shall not exceed clearance dimensions shown on the INL drawings.

3.3.2.9 If the glovebox shell requires reinforcement, stiffening shall be incorporated in accordance with AGS-G006-2005

Section 4.3.2. All reinforcement shall be mounted to the exterior and welded. Bolted reinforcement members are not permitted. The size and number of stiffening members shall be minimized while meeting the requirements of 3.3.1.7. Stiffening members should be mounted with exterior plug welds in lieu of fillet welds to minimize distortion.

\subsubsection{Windows}

3.3.3.1 One spare window shall be provided for each window configuration installed in the glovebox. 
URANIUM PROTOTYPE GLOVEBOX AND FURNACE DESIGN AND BUILD

$\begin{array}{lll}\text { Identifier: } & \text { SPC-2954 } \\ \text { Revision: } & 0 \\ \text { Effective Date: } & 01 / 19 / 21\end{array}$

Page: 19 of 50

3.3.3.2 Windows shall be mounted external to the shell of the glovebox. Each window frame used for securing the confinement boundary windows to the glovebox shell shall be a single weldment.

3.3.3.3 Windows shall be constructed as specified on INL drawings using Material Option B.

3.3.3.4 Gaskets for Confinement Windows

3.3.3.4.1 Gasket materials shall be 35 to 45 durometer (Shore A) neoprene rubber per ASTM D2000. All gaskets shall be of a continuous or mitered and vulcanized construction. Alternate materials may be used with prior INL approval. Gaskets for confinement windows shall have U-shaped cross-sections that they wrap around the outside edges of the window in accordance with AGS-G001, Appendix A, drawing AGS006. The legs of the U-shape shall be long enough to extend beyond the glovebox shell opening and be trimmed to match the opening (Figure 2). Gasket seams shall not be in the corners. Windows shall be provided with the gaskets installed on the windows. Two spare gaskets shall be provided for each window type in each glovebox.

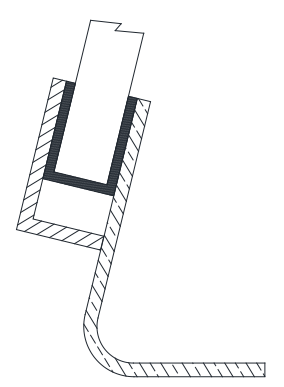

Correct gasket length

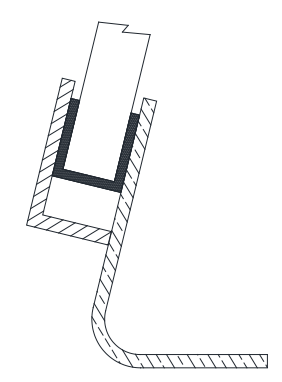

Incorrect length

Figure 2. Window Gasket Installation 


\begin{tabular}{l|lll|} 
URANIUM PROTOTYPE GLOVEBOX & Identifier: & SPC-2954 & \\
AND FURNACE DESIGN AND BUILD & Revision: & 0 & \\
& Effective Date: & $01 / 19 / 21$ & Page: 20 of 50 \\
\hline
\end{tabular}

\subsubsection{Gloveports and Bagports}

3.3.4.1 Glove rings shall be installed at the locations shown on the drawings.

3.3.4.2 Glove rings for windows shall be 8-in. round clamp-in style, CRL part no. 42686 for safety glass windows. Glove rings with associated gasket sets and ejectable port plugs will be provided as GFE.

3.3.4.3 Two bagports, an 8-in round weld-in style enclosure ring, CRL part no. 37969 and a 15-in. round weld-in style enclosure ring, CRL part no. 50580 shall be installed. The bag rings and ejectable port plugs will be provided as GFE.

3.3.4.4 The 15-in. round bag port shall incorporate an interior SST door, MBraun part no. 8041721. The door assembly and mounting hardware will be provided as GFE.

\subsubsection{Penetrations}

3.3.5.1 AGS-G006-2005 Section 4.5.6 applies to penetrations except some penetrations are made in the shell as shown in the drawings.

3.3.5.2 All penetrations shall be through the ceiling, or end panels of the glovebox with the exception of the furnace power feedthrough. Except for gloveports, penetrations through windows are not permitted.

3.3.5.3 Penetration locations shall not compromise accessibility or interfere with the movement (swing) of the airlock door. Connectors and tools for the penetrations shall be able to fit on the penetrations without interference with neighboring penetrations, the wall of the glovebox, or other obstructions.

3.3.5.4 The subcontractor shall provide spare penetrations as shown on the drawing.

3.3.5.5 CF-style penetrations (inside and outside) shall be provided with seals, clamps, and blank flanges if unused. All CFseals shall use silver-plated copper construction.

3.3.5.6 KF-style penetrations (inside and outside) shall be provided with seals, clamps, and blank flanges if unused. All KFfittings shall use FKM O-rings. 
URANIUM PROTOTYPE GLOVEBOX AND FURNACE DESIGN AND BUILD

$\begin{array}{lll}\text { Identifier: } & \text { SPC-2954 } \\ \text { Revision: } & 0 \\ \text { Effective Date: } & 01 / 19 / 21\end{array}$

Page: 21 of 50

3.3.5.7 Unused NPT coupling penetrations shall be provided with stainless steel plugs installed both on the inside and outside of the glovebox.

3.3.5.8 All penetrations shall be seal welded on interior joints and skip or seal welded on exterior joints of the glovebox shell.

3.3.5.9 Install two PAVE 2063-3 into the glovebox and terminate interior cables to boxes with Type-K thermocouple female plugs near the well ports.

3.3.5.10 Additional PAVE connectors for the use of high temperature Type $\mathrm{R}$ or $\mathrm{S}$ thermocouples based on furnace design.

3.3.5.11 Provide two cable trays in the glovebox located below upper side windows for cable management including support of the hoist power cable.

\subsubsection{Electrical Feedthroughs and Power Distribution Equipment}

3.3.6.1 All electrical wiring and equipment shall comply with the current National Electrical Code, NFPA 70.

3.3.6.2 208VAC/120VAC, 5-wire, lighting/power panel shall be provided on the glovebox, as shown on the drawings, with known loads (e.g., lights, receptacles, and so forth) prewired. Lighting panels shall be UL listed and a minimum 10,000 AIC rating. The box or panel shall contain a main breaker. Normal power from the facility shall connect to each panel from a single connection(breaker).

3.3.6.3 All electrical circuits for each glovebox shall be fed from the lighting panels such that the glovebox has one facility power feed. Anticipated circuits consist of following:

\begin{tabular}{|lllll|}
\hline $\begin{array}{c}\text { Circuit } \\
\text { No }\end{array}$ & Voltage & Current & \multicolumn{1}{c|}{ Description } & Location \\
\hline n/a & $208 \mathrm{~V}$ & $20 \mathrm{~A}$ & MB300 Purifier & TBD \\
\hline 1 & $120 \mathrm{~V}$ & $20 \mathrm{~A}$ & Lights & Glovebox \\
2 & $120 \mathrm{~V}$ & $20 \mathrm{~A}$ & $\begin{array}{l}\text { East External Receptacles } \\
\text { West (and roof) External }\end{array}$ & Glovebox \\
& & & Receptacles & Glovebox \\
4 & $120 \mathrm{~V}$ & $20 \mathrm{~A}$ & NE Interior Receptacles & Glovebox \\
\hline
\end{tabular}




\begin{tabular}{|l|lll|} 
URANIUM PROTOTYPE GLOVEBOX & Identifier: & SPC-2954 & \\
AND FURNACE DESIGN AND BUILD & Revision: & 0 & \\
& Effective Date: & $01 / 19 / 21$ & Page: 22 of 50 \\
\hline
\end{tabular}

\begin{tabular}{|lllll|}
\hline $\begin{array}{c}\text { Circuit } \\
\text { No }\end{array}$ & Voltage & Current & \multicolumn{1}{c|}{ Description } & Location \\
\hline 5 & $120 \mathrm{~V}$ & $20 \mathrm{~A}$ & NW Interior Receptacles & Glovebox \\
6 & $120 \mathrm{~V}$ & $20 \mathrm{~A}$ & SE Interior Receptacles & Glovebox \\
7 & $120 \mathrm{~V}$ & $20 \mathrm{~A}$ & NW Interior Receptacles & Glovebox \\
8 & $208 \mathrm{~V}$ & $20 \mathrm{~A}$ & Interior Receptacle & Glovebox \\
9 & $208 \mathrm{~V}$ & $30 \mathrm{~A}$ & L5-30R Heat sealer receptacle & Glovebox \\
10 & $208 \mathrm{~V}$ & $20 \mathrm{~A}$ & Spare & Glovebox \\
11 & $120 \mathrm{~V}$ & $20 \mathrm{~A}$ & Spare & Glovebox \\
12 & $120 \mathrm{~V}$ & $20 \mathrm{~A}$ & Spare & Glovebox \\
\hline
\end{tabular}

3.3.6.4 All panel circuit breakers shall have a permanently attached lockout device.

3.3.6.5 Junction boxes and lighting panels should be sized to allow approximately $30 \%$ spare circuit breakers. Spare $20 \mathrm{amp}$ circuit breakers shall be installed to fill all blank spaces. Conductors shall not be terminated on breakers identified as spares.

3.3.6.6 Power to interior electrical equipment shall be supplied via hermetically sealed electrical feedthroughs. Interiormounted electrical receptacles in stainless steel boxes shall be installed in locations shown on the drawings.

3.3.6.7 All electrical feedthroughs shall be through the ceiling, walls, or end plate(s) of the glovebox with the exception of the furnace power feedthrough. Electrical feedthroughs are not permitted through windows.

3.3.6.8 Receptacle boxes shall be mounted through the wall of the glovebox as shown on Figure 3. Elevation of gang boxes should be per Figure 3 or as shown on INL drawings. Gang boxes interior surfaces shall have a surface finish equivalent to the glovebox interior. Gang boxes shall be Crouse-Hinds, Calbrite or equivalent. 


\begin{tabular}{|l|lll|}
\hline URANIUM PROTOTYPE GLOVEBOX & Identifier: & SPC-2954 & \\
AND FURNACE DESIGN AND BUILD & Revision: & 0 & \\
& Effective Date: & $01 / 19 / 21$ & Page: 23 of 50 \\
\hline
\end{tabular}
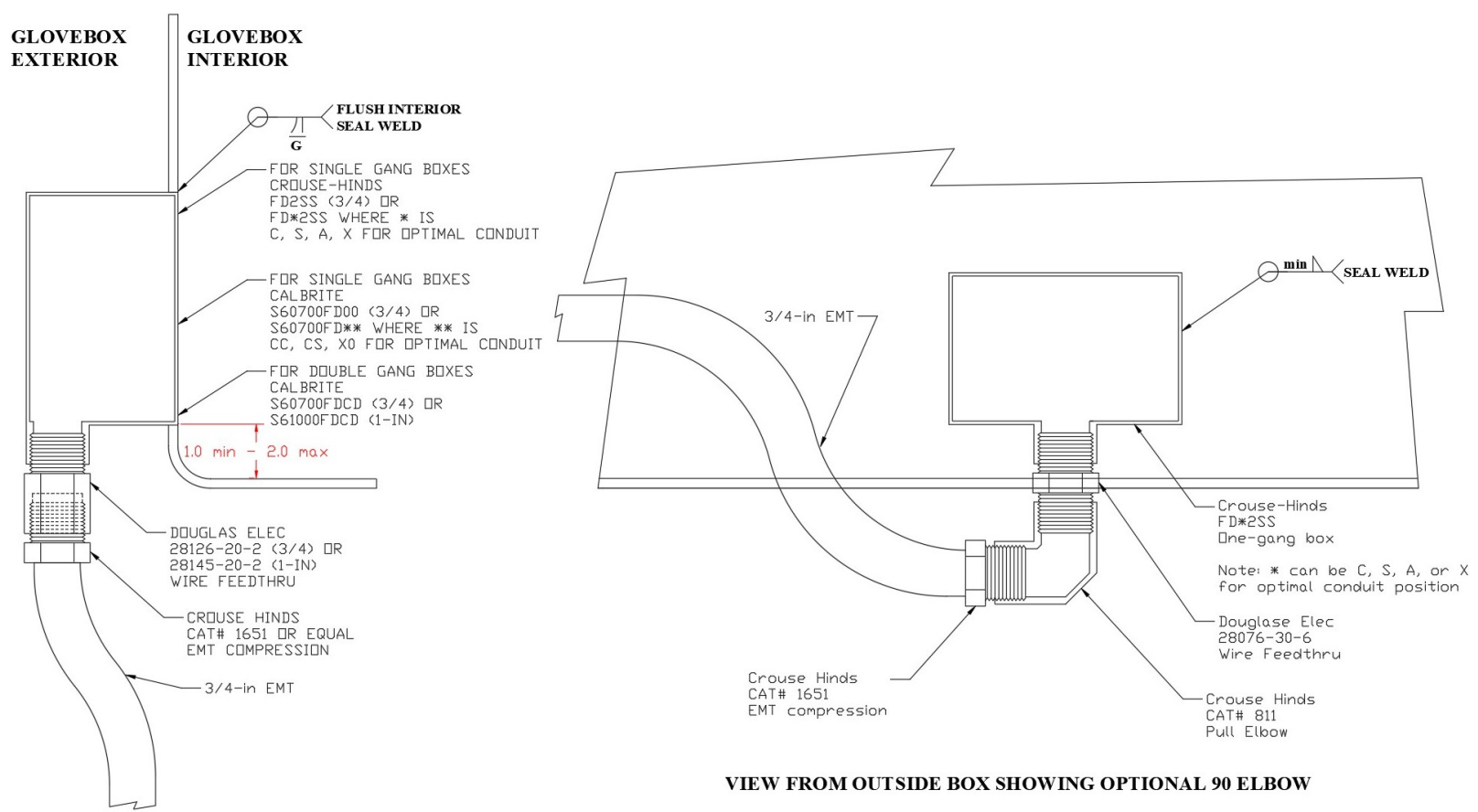

Figure 3. Receptacle Junction Box Installation.

3.3.6.9 Manufacturers Pave-Mate ${ }^{\mathrm{d}}$, or Douglas Electric, or KF-type penetrations are recommended for electrical/instrumentation feedthroughs.

3.3.6.10 All electrical power circuits shall include an equipment ground conductor as required by the NEC and IEEE-1100. All equipment (including the glovebox shell, purification cabinet, receptacles, and laboratory equipment) shall be effectively grounded through the equipment ground bus inside the electrical panel. (The glovebox and equipment grounding circuits will be grounded to the facility system by INL.)

3.3.6.11 Raceways shall not be used as an equipment grounding conductor.

3.3.6.12 Conduit runs shall be run external to the glovebox, unless otherwise approved by the INL.

3.3.6.13 Electrical equipment, except for the furnace, shall be compatible with 208 VAC three phase, or 120/208 VAC single phase power.

d. Pave Technology Company; refer to paragraph 7.3.2. 


\begin{tabular}{l|lll|} 
URANIUM PROTOTYPE GLOVEBOX & Identifier: & SPC-2954 \\
AND FURNACE DESIGN AND BUILD & Revision: & 0 & \\
& Effective Date: & $01 / 19 / 21$ & Page: 24 of 50 \\
\hline
\end{tabular}

3.3.6.14

3.3.6.15

3.3.6.16

3.3.6.17

3.3.6.18

3.3.6.19

3.3.6.20

3.3.6.21

3.3.6.22

3.3.6.23 Electrical equipment shall be de-rated for operation at 5000' elevation.

All applications, including lights, purification system operation, cooling, convenience outlets, and so forth, should be based on 20-amp normal power circuits as applicable.

Color code for three phase circuits shall be Phase A-Black, Phase B-Red, Phase C-Blue, Neutral-White and Ground-Green or bare.

The subcontractor shall attach labels with unique identifiers to each end of all conductors to identify both the local termination and the opposite end termination, (i.e. TB1-6 to TB5-3), and that information shall be included on wiring diagrams. (Refer to paragraph 3.8.1.) The subcontractor shall coordinate the labeling scheme with INL.

Control cabinets shall be designed and constructed to be finger safe as defined by IEC-60529.

All enclosures containing IP20 rated terminations shall be labeled "FINGER-SAFE TERMINATIONS INSIDE."

The electrical and control enclosures shall be labeled in accordance with ISA 60.6 and INL standard INL-STD-139-26 0001.

All electrical equipment including industrial control panels shall have a short circuit current rating of 10kA and comply with the requirements of NFPA-70 and specifically Article 409 for Industrial Control Panels. PLC cabinet labels shall comply with requirements for industrial control cabinets per NEC 409.110.

Control cabinet shall be UL 508a listed or certified by a Nationally Recognized Testing Laboratory (NRTL).

$\mathrm{AC}$ power distribution within a console enclosure, cabinet or panel shall be configured to provide physical separation from signal cabling.

Electrical equipment shall be de-rated for operation at 5000' evation. 


\begin{tabular}{|l|lll|}
\hline URANIUM PROTOTYPE GLOVEBOX & Identifier: & SPC-2954 & \\
AND FURNACE DESIGN AND BUILD & Revision: & 0 & \\
& Effective Date: & $01 / 19 / 21$ & Page: 25 of 50 \\
\hline
\end{tabular}

\subsubsection{Glovebox Illumination}

3.3.7.1 Lighting shall be located outside the glovebox confinement boundary to limit contamination and for ease of maintenance. Lighting shall be located on top of the glovebox and fixtures shall be located as shown on the drawings.

3.3.7.2 Lighting fixtures shall be Philips dimmable compact, high performance LED fixtures ${ }^{\mathrm{e}}$ model 523-000065-15 or INL approved equal. Three fixtures shall be provided per location shown on the drawings.

3.3.7.3 Housings that enclose the three fixtures shall provide adequate ventilation to release heat from the enclosure. INL recommend at least $40 \%$ of the housing surface area be open, for example no sides on the light housings.

3.3.7.4 Glovebox lighting shall be controlled by dimming switches installed in accordance with Figure 4. The switches shall be located in an easily accessible location.

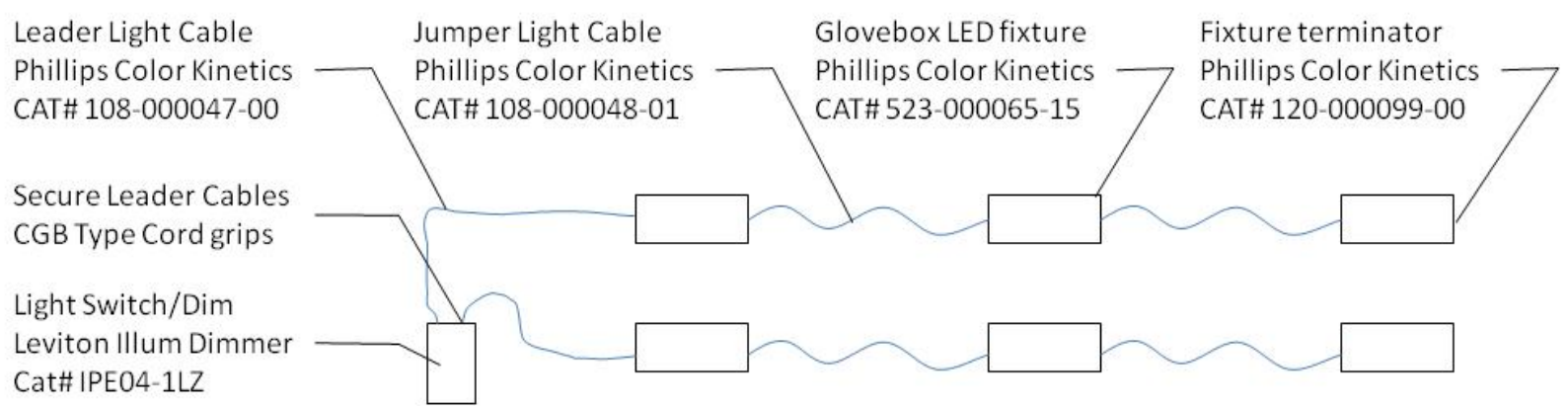

Figure 4. Lighting Installation Schematic.

\subsubsection{Airlock}

3.3.8.1 The glovebox shall be equipped with one MBraun airlock, similar to MBraun drawing 8016563 (proprietary). This airlock will mate to another glovebox or hood. The airlock, doors, and ancillary hardware will be provided as GFE.

3.3.8.2 The airlock doors shall not interfere with penetrations, receptacles, or other appurtenances, and shall be capable of fully opening without interference with the glovebox shell.

e. Philips Color Kinetics, Inc., 3 Burlington Woods Dr., Burlington MA 01803

TEL: 888-385-5742, FAX: 617-338-0454, www.philips.com 


\begin{tabular}{l|lll|} 
URANIUM PROTOTYPE GLOVEBOX & Identifier: & SPC-2954 \\
AND FURNACE DESIGN AND BUILD & Revision: & 0 & \\
& Effective Date: & $01 / 19 / 21$ & Page: 26 of 50 \\
\hline
\end{tabular}

\subsubsection{Ventilation Filters}

3.3.9.1 All glovebox gaseous penetrations shall be filtered inside the confinement boundary of the glovebox except when specified.

3.3.9.2 The glovebox ventilation penetrations to and from the purification system shall use a 5" diameter Flanders HEPA radial filter (Model 0-007-1-43-RF-NU-51-E3-Z14239). The HEPA filters shall be mounted using the custom mount shown in the drawings.

3.3.9.3 The glovebox secondary exhaust penetration shall use a 5" diameter Flanders HEPA radial filter (Model 0-007-1-43RF-NU-51-E3-Z11410). The HEPA filter shall be mounted using the custom mount shown in the drawings

\subsubsection{Hoist}

3.3.10.1 The glovebox shall incorporate an overhead hoist as shown in the INL drawings.

3.3.10.2 The hoist shall be a trolley and bridge type.

3.3.10.3 The hoist shall travel within the required end approaches and minimal hook travel as shown in the INL drawings. Hook travel is electrically operated. Bridge and trolley travel are manually operated.

3.3.10.4 The glovebox shall be designed to support $125 \%$ of the hoist's capacity.

3.3.10.5 The hoist's capacity shall be $500 \mathrm{lb}$.

3.3.10.6 Hoist design shall meet applicable requirements of ASME B30.17.

3.3.10.7 The hoist motor must be compatible with the argon atmosphere within the glovebox (brushless).

3.3.10.8 The hoist lift shall provide variable or minimum two speed capability. (Minimum speed of $1 \mathrm{ft} / \mathrm{min}$ or less and maximum speed of approximately $6 \mathrm{ft} / \mathrm{min}$ ).

3.3.10.9 The hoist shall not use wire rope for lifting.

3.3.10.10 The lifting chain/strap should be captured to avoid contacting windows and equipment inside glovebox. 
URANIUM PROTOTYPE GLOVEBOX AND FURNACE DESIGN AND BUILD

$\begin{array}{lll}\text { Identifier: } & \text { SPC-2954 } \\ \text { Revision: } & 0 \\ \text { Effective Date: } & 01 / 19 / 21\end{array}$

3.3.10.11 The hoist cable management system shall incorporate the use of a flexible cable track and supporting cable tray.

3.3.10.12 Hoist shall be able to fit through the 15 " bag port.

3.3.10.13 Hoist assembly shall be free of oil or other liquid.

3.3.10.14 Hoist shall be housed and finished to facilitate the decontamination of the hoist.

\subsection{Atmosphere Control Systems}

The purification system outlined in this section will be provided as GFE.

3.4.1 The glovebox shall be plumbed in accordance with the INL P\&ID and parts list. The parts list can be found in Appendix A.

\subsubsection{Purification and Primary Pressure Control System}

3.4.2.1 The glovebox shall have a dedicated purification system for maintaining oxygen and moisture levels. The purification system also provides glovebox pressure control.

3.4.2.2 The purification system for the glovebox shall be an MBraun 300.

3.4.2.2.1 Power to the purification system will be 208volt 3 phase.

3.4.2.2.2 All pneumatic actuated valves outside the glovebox will be operated with compressed air and all pneumatic actuated valves inside the glovebox, if included, will be operated with the working gas.

\subsubsection{Secondary Exhaust}

3.4.3.1 The glovebox shall have a dedicated secondary exhaust controlled by the purification system. The parts for this feature are identified in the P\&ID and parts list.

\subsubsection{Pressure Relief System}

3.4.4.1 The glovebox shall incorporate a pressure relief system to limit the maximum glovebox pressure to $\pm 5.0 \mathrm{in}$. of water. 
URANIUM PROTOTYPE GLOVEBOX AND FURNACE DESIGN AND BUILD

\begin{tabular}{|lll|} 
Identifier: & SPC-2954 & \\
Revision: & 0 & \\
Effective Date: & $01 / 19 / 21$ & Page: 28 of 50 \\
\hline
\end{tabular}

3.4.4.2 The pressure relief system shall utilize a three, bidirectional bubbler assembly MBraun ${ }^{\mathrm{f}}$ model 8015676 . The pressure relief systems shall be provided as GFE.

3.4.4.3 The pressure relief system shall be located per INL drawings.

\subsubsection{Atmosphere Cooling}

3.4.5.1 The glovebox has dedicated cooling units to expel heat introduced to the glovebox atmosphere by process equipment. The cooling units are controlled by the purification system shall be provided as GFE.

\subsection{Monitors and Alarms}

\subsubsection{Atmosphere Monitoring.}

3.5.1.1 The glovebox shall have a dedicated oxygen analyzer. NTRON $^{\mathrm{g}}$ model SenzTX, as listed in Appendix A. The analyzer shall be installed as shown on INL drawings and wired to the purification system. The analyzer shall be provided as GFE.

3.5.1.2 The glovebox shall have a dedicated moisture analyzer. Vaisala model DMT152 B1DED1XA500A1A with pressure setting 0.825 bar, as listed in Appendix A. The analyzer shall be installed as shown on INL drawings and wired to the purification system. The analyzer shall be provided as GFE.

3.5.1.3 Calibration capability for the analyzers shall be provided and plumbed as shown on the P\&ID.

\subsubsection{Heat Detection System.}

3.5.2.1 The glovebox shall be equipped with a heat detection well and support hardware per INL drawing 853554. The heat detector and associated wiring will be installed by INL.

f. Refer to Section 2.3.

g. NTRON via Rotonic Instrument Corp, 135 Engineers Road, Suite 150, Hauppauge, NY 11788

Tel: 631-427-3898, Fax: 631-427-3902, Web: www.frotonic-usa.com 
URANIUM PROTOTYPE GLOVEBOX AND FURNACE DESIGN AND BUILD

\begin{tabular}{|lll|} 
Identifier: & SPC-2954 & \\
Revision: & 0 & \\
Effective Date: & $01 / 19 / 21$ & Page: 29 of 50 \\
\hline
\end{tabular}

\subsubsection{Radiation Monitoring Equipment Mounts}

3.5.3.1 The Subcontractor shall fabricate and install mounts for hand frisker at locations shown on INL drawings.

\subsection{Performance Requirements}

3.6.1 The glovebox enclosure shall be capable of maintaining the integrity of the confinement boundary when subjected to the conditions outlined herein.

3.6.2 Leakage - There shall be no detectable leakage in excess of $1 \times 10^{-4} \mathrm{cc} / \mathrm{sec}$ for the assembled glovebox system when tested in accordance with Section 5.3.1.5.

3.6.3 Operating Temperature - All gasket and clamping systems shall be designed to allow expansion and contraction of different materials (in particular the windows and associated seals) over a temperature range between 50 and $110^{\circ} \mathrm{F}$ without a loss in the seal between the interior and exterior of the glovebox enclosure.

3.6.4 Operating Pressure - All gasket and clamping systems shall be designed to allow the expansion and contraction of different materials (in particular the windows and associated seals) to withstand a pressure differential of $\pm 61 / 4$ inch of water between the glovebox interior and exterior without damage or loss of function.

3.6.5 Natural Phenomena Requirements - The glovebox shell (including confinement boundary filters), structural support frame, and anchorage shall be designed to meet Performance Category 2 (PC-2), per DOESTD-1020, "Natural Phenomena Hazards Analysis and Design Criteria for DOE Facilities." Per the identified performance category, the confinement boundary shall remain intact following the defined seismic event.

3.6.5.1 In lieu of performing a seismic analysis, an equivalency evaluation shall be documented to demonstrate that the glovebox is equivalent to the Fuel Manufacturing Glovebox designed per SPC-2842.

3.6.5.2 Floor anchors allowed are Hilti Kwik Bolts TZ KB-TZ $1 / 2 \times 5-1 / 2$, per INL established practice. The number of anchor pads and anchors shall be minimized, i.e., one anchor per anchor pad. 


\begin{tabular}{l|lll|} 
URANIUM PROTOTYPE GLOVEBOX & Identifier: & SPC-2954 & \\
AND FURNACE DESIGN AND BUILD & Revision: & 0 & \\
& Effective Date: & $01 / 19 / 21$ & Page: 30 of 50 \\
\hline
\end{tabular}

\subsection{Glovebox Utilities and Interfaces}

This section provides the interface and utility information required for the subcontractor to complete the design of the glovebox. The subcontractor has no responsibility for connection of the glovebox utilities at INL other than providing the specified connection points and assembly instructions as specified on the drawings or in this specification.

\subsubsection{Suspect Exhaust System}

3.7.1.1 The facility suspect exhaust system operates at -0.5 to -2.0-iwg differential pressure relative to the work area and provides a vent path for all glovebox exhaust streams.

3.7.1.2 The facility suspect exhaust system flows approximately $6,000 \mathrm{cfm}$.

\subsubsection{Power Distribution System}

3.7.2.1 The facility will provide the following power circuits:

- $\quad$ AC Power Normal, 277/480V, 3 Phase, $60 \mathrm{~Hz}$

- $\quad$ AC Power Normal, 120/208V, 3 Phase, $60 \mathrm{~Hz}$

- $\quad$ AC Power Standby, 120/280V, 3 Phase, 60 Hz.

\subsubsection{Argon Gas Supply System}

3.7.3.1 The facility will supply argon for the glovebox atmosphere and pressure control systems. Connection points shall be provided as shown on the drawings.

3.7.3.2 The facility argon distribution system operates at pressures between 80-psig and 100-psig.

\subsubsection{Instrument Air System}

3.7.4.1 The facility will supply dry instrument air (ISO Class 4 $38^{\circ} \mathrm{F}$ dew point) to operate valve actuators as needed. Input pressure is 120-psig maximum, operating pressure is 80-psig.

\subsubsection{Regeneration Gas System}

3.7.5.1 An argon/hydrogen regeneration gas mixture will be provided by the facility. 


\begin{tabular}{l|lll|} 
URANIUM PROTOTYPE GLOVEBOX & Identifier: & SPC-2954 & \\
AND FURNACE DESIGN AND BUILD & Revision: & 0 & \\
& Effective Date: & $01 / 19 / 21$ & Page: 31 of 50 \\
\hline
\end{tabular}

\subsection{Drawing and Configuration Control Requirements}

\subsubsection{Fabrication Drawings}

3.8.1.1 The subcontractor shall prepare detailed fabrication drawings that fully implement the design layout specified by the contract drawings and the requirements of this specification. Electrical plans, schematics (as applicable), and wiring diagrams shall be provided. The Subcontractor may use Pro-Engineer ${ }^{\mathrm{TM}}$ or other three dimensional parametric modeling software convertible to either a ProEngineer or AutoCAD ${ }^{\mathrm{TM}}$ drawing format. For designs conducted in two dimensions, drawings must be convertible to AutoCAD.

3.8.1.2 The drawings shall conform to all design, material, fabrication, assembly, and test requirements of this specification. All information pertinent to the fabrication, assembly, or test of a component or assembly shall be specified on the drawing for that component or assembly. Drawings shall specify any torque values needed to control gasket compression.

3.8.1.3 All special processes shall be specified on the drawings by the applicable specification or procedure number.

3.8.1.4 Equipment and components shall be specified on the drawings by size, manufacturer, and catalog number. In addition to size and shape, raw materials shall be specified by ASTM designation. Specification of materials shall include the type or grade of material. Catalog data shall be provided for all equipment and components, including electrical schematics and wiring diagrams where applicable.

3.8.1.5 Dimensions and tolerances shall conform to the requirements of ANSI Y14.5. Either mechanical or architectural drawing format is acceptable. Drawings shall be drawn to scale.

3.8.1.6 Drawings shall be submitted in accordance with the Vendor Data Schedule. Fabrication drawings shall be submitted to and approved by INL prior to start of fabrication of any given item. The subcontractor shall implement no changes to the approved fabrication drawings without the written approval of INL. 


\begin{tabular}{l|lll|} 
URANIUM PROTOTYPE GLOVEBOX & Identifier: & SPC-2954 & \\
AND FURNACE DESIGN AND BUILD & Revision: & 0 & \\
& Effective Date: & $01 / 19 / 21$ & Page: 32 of 50 \\
\hline
\end{tabular}

\subsubsection{As-Built Drawings}

3.8.2.1 After fabrication and assembly have been completed and accepted by INL, the fabrication drawings shall be revised to reflect the "as-built" condition. These as-built drawings shall reflect all modifications to and deviations from the fabrication drawings that have been approved by INL and subsequently implemented by the subcontractor. Actual dimensions deviating from the nominal, but within the tolerance of the supplied drawings, shall not be noted as exceptions. The subcontractor shall furnish INL with signed copies of the drawings in .pdf format. In addition, the subcontractor shall furnish INL with electronic native files of the 2D drawings in AutoCAD .dwg format and 3D models (if created) in Pro-E or .step format.

\section{FABRICATION REQUIREMENTS}

\subsection{Fabrication and Workmanship}

\subsubsection{Prohibitions}

4.1.1.1 Controls are to be exercised during all stages of fabrication to minimize exposure of stainless steel to contaminants, particularly chlorides. Chloride-bearing compounds shall be avoided. However, if used, they shall be completely removed by thorough cleaning. Any compounds and liquids that come into contact with stainless steel surfaces shall not contain more than 250-ppm by weight of chlorides. Cutting of stainless steel shall be performed with mechanical shop tools, plasma arc, laser, or water jet. Carbon arc or iron powder cutting shall not be permitted on stainless steel.

4.1.1.2 Markings on 300 series stainless steel shall be made with products containing less than 100-ppm total chloride/halogen content.

\subsubsection{Welding}

4.1.2.1 Stainless steel welding shall be performed in accordance with AWS D1.6.

4.1.2.2 AGS-G006-2005 Sections 5.2.1 through 5.2.5 and 5.2.8 apply to welding. Documentation shall be submitted to the INL for approval prior to performing any welding. (Refer to the Vendor Data Schedule). 
URANIUM PROTOTYPE GLOVEBOX AND FURNACE DESIGN AND BUILD
Identifier: Revision:

Effective Date: $01 / 19 / 21$

0
SPC-2954

Page: 33 of 50

4.1.2.3 As an alternate, the subcontractor may use welders and procedures qualified in accordance with AWS B2.1, or any nationally recognized and accepted code with the approval of the INL.

4.1.2.4 As an alternate, welding may be performed under the INL weld program. Welders shall be qualified under the INL weld program if this option is utilized.

4.1.2.5 Welding (except studs) shall be performed using a Gas Tungsten Arc Welding (GTAW) process with inert gas shielding and direct current, work positive polarity. Confinement welds shall be multiple pass to ensure gas tightness.

4.1.2.6 Brushing on stainless steel shall be done with a clean stainless steel brush not previously used on other materials. In no case shall a carbon steel brush be used on stainless steel.

4.1.2.7 Interior welds shall be polished per Figure 5. Photos depict acceptable and unacceptable welds.

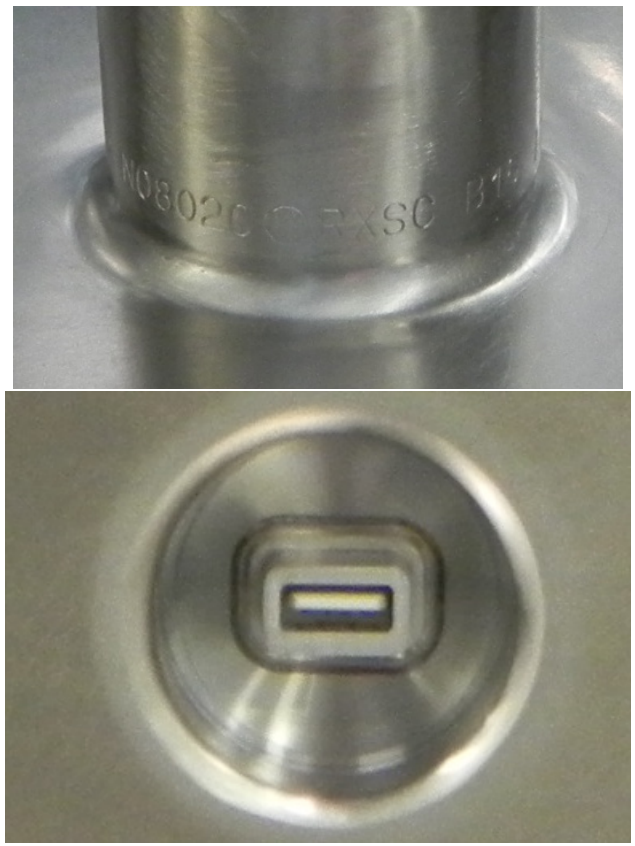

Acceptable Finish

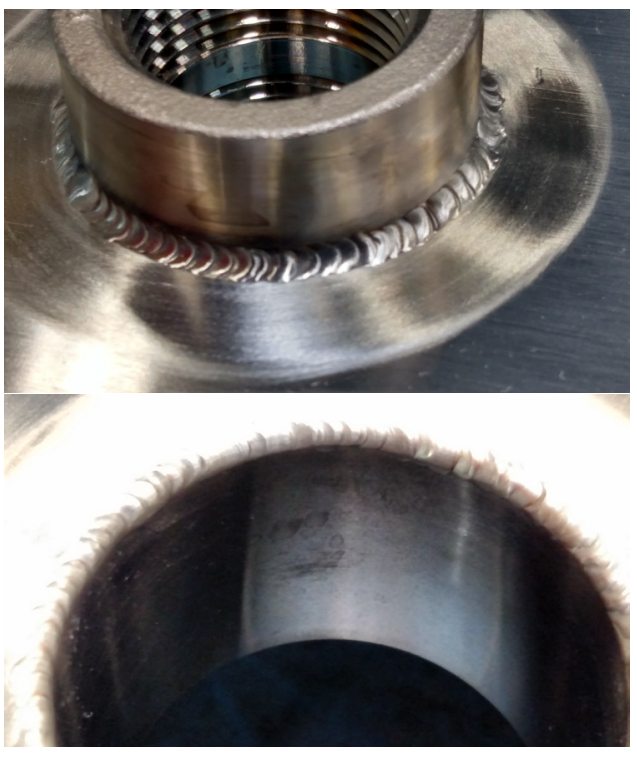

Unacceptable Finish

Figure 5. Weld finishes. 
URANIUM PROTOTYPE GLOVEBOX AND FURNACE DESIGN AND BUILD
Identifier: Revision:

Effective Date: $01 / 19 / 21$
SPC-2954

0
Page: 34 of 50

4.1.2.8 Exterior tubing welds shall be minimum fusion welds per Figure 6. Photos depict examples of acceptable welds.
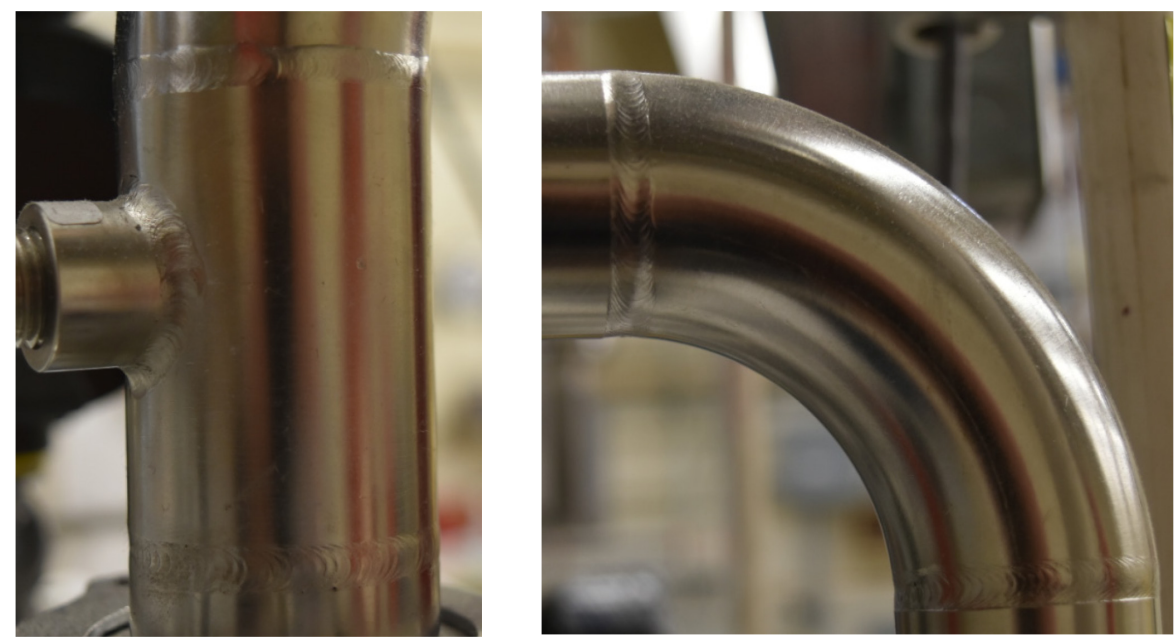

Figure 6. Tube Weld finishes.

\subsubsection{Stud Welding}

4.1.3.1 Welding of threaded studs shall be performed in accordance with AGS-G006-2005 Section 5.2.12, and the following:
4.1.3.1.1 Documentation shall be submitted to the INL for approval prior to performing any welding. (Refer to the Vendor Data Schedule).

4.1.3.1.2 Studs shall be installed using an automatic weld machine (stud gun).

\subsubsection{Fit and Finish}

4.1.4.1 All mill and fabrication markings (such as center punch marks, scribe lines, and stamp marks) shall be removed. All exposed surfaces shall be free of sharp edges, cracks, pits, oxides, burns, weld splatter, sharp ridges, grooves, tool marks, or any other surface irregularities.

4.1.4.2 AGS-G006-2005 Section 5.5.1 applies to finish. Interior and sealing surfaces shall be polished to a 16 micro-inch finish.

4.1.4.3 AGS-G006-2005 Section 5.5.2 applies to grinding. 
URANIUM PROTOTYPE GLOVEBOX AND FURNACE DESIGN AND BUILD

\begin{tabular}{lll|} 
Identifier: & SPC-2954 & \\
Revision: & 0 & \\
Effective Date: & $01 / 19 / 21$ & Page: 35 of 50 \\
\hline
\end{tabular}

4.1.4.4 AGS-G006-2005 Section 5.1.1 applies to glovebox flatness. Glovebox floor surfaces within a 3-ft. x 3-ft. plane shall be flat within 1/32-in as measured from a standard reference plane. The entire floor surface shall be flat within 1/16-in as measured from a standard reference plane.

4.1.4.5 AGS-G006-2005 Section 5.1.2 applies to sealing surfaces. Window frame sealing surfaces shall be flat within 1/32-in. per foot after welding. All sealing surface points within a 3-ft. x 3-ft. plane shall be flat within 1/16-in. as measured from a standard reference plane. The entire window opening shall be flat within 1/8-in. as measured from a standard reference plane.

4.1.4.6 AGS-G006-2005 Section 5.1.3 applies to dimensional tolerances. With respect to AGS-G006-2005

Section 5.1.3.3, parallelism shall not exceed 1/8-in and squareness shall not exceed 3/16-in for glovebox dimensions larger than $8 \mathrm{ft}$.

4.1.4.7 In no event shall SST sheet be bent to an interior radius less than three times the thickness of the material unless otherwise noted on the drawings.

4.1.4.8 All tubing cuts shall be square and interior edges reamed smooth.

4.1.4.9 All tubing, piping and flange fit-ups shall be aligned without stressing of components. For example, bolt holes on flanges shall line up without force.

4.1.4.10 All assembled Swagelok TM compression fittings shall be verified with manufacturer gap inspection gauges

4.1.4.11 The exterior finish of the shell weldment and support frame shall be finished with a thermoset powder coating in accordance with AAMA 2604. Color will be specified or agreed to during design.

\subsubsection{Threaded joints}

4.1.5.1 Confinement boundary threads shall be sealed. Neolube ${ }^{\circledR}$ Thread Sealant No. 100 or equally low halogen content sealant that does not contain PTFE shall be applied to all NPT confinement threads. 


\begin{tabular}{l|lll|} 
URANIUM PROTOTYPE GLOVEBOX & Identifier: & SPC-2954 & \\
AND FURNACE DESIGN AND BUILD & Revision: & 0 & \\
& Effective Date: & $01 / 19 / 21$ & Page: 36 of 50 \\
\hline
\end{tabular}

\subsubsection{Windows}

4.1.6.1 Window surfaces shall be protected at all times to prevent marring or scratching. The penetrations for glove ports shall be cut in the window to the dimensions shown on the drawings. Hole locations shall be as specified on the drawing(s).

\subsubsection{Gloveport Installation}

4.1.7.1 Gloveports installed in glass shall conform to manufacturer assembly and installation instructions. Specifically, a fourpiece gasket set shall be installed per Figure 7. The backing plate shall be CRL-18453.

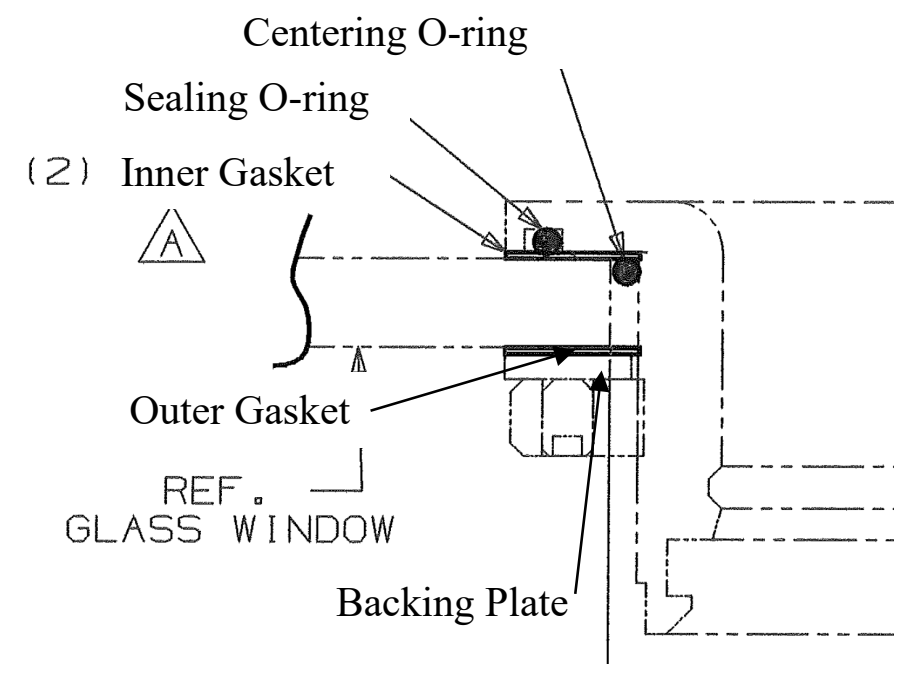

Figure 7. Gloveport Installation.

\subsection{Identification and Marking}

4.2.1 The subcontractor shall attach an identification nameplate to the shell of each glovebox module in accordance with AGS-G006-2005 Section 4.23 except lettering shall be at least $1 / 4 \mathrm{in}$. high. The nameplate must be visible after assembly. For rigging purposes, identify weight of upper shell assembly and the total glovebox assembly separately.

\subsection{Cleaning}

4.3.1 The glovebox shall be cleaned in accordance with AGS-G006-2005 Section 5.6. All windows shall be carefully cleaned in accordance with manufacturer's recommendations. The cleanliness of the enclosure shall meet the approval of INL at the time of final inspection. 
URANIUM PROTOTYPE GLOVEBOX AND FURNACE DESIGN AND BUILD

\begin{tabular}{|lll|} 
Identifier: & SPC-2954 & \\
Revision: & 0 & \\
Effective Date: & $01 / 19 / 21$ & Page: 37 of 50 \\
\hline
\end{tabular}

\subsection{Acceptance}

4.4.1 After fabrication, the glovebox shall be assembled in the subcontractor's shop to assure proper fit and operation. The Laboratory's technical representative(s) shall inspect the assembled final product prior to disassembly for shipment.

\section{QUALITY ASSURANCE PROVISIONS}

The subcontractor shall maintain a documented Quality Assurance Program.

\subsection{Standard INL Quality Assurance Requirements}

5.1.1 The subcontractor shall comply with INL quality assurance requirements (from INL document STD-4507) identified in Table 1.

Table 1. INL Quality Assurance Requirements

\begin{tabular}{|c|c|c|}
\hline ID & Description & Applicability \\
\hline 121 & $\begin{array}{l}\text { Standard Requirement Flow- } \\
\text { down }\end{array}$ & $\begin{array}{l}\text { Analysis sub-tier vendor } \\
\text { Shell fabrication (if sub-tier) } \\
\text { Furnace supplier }\end{array}$ \\
\hline 341 & Design Review & $\begin{array}{l}\text { Applies to drawings and analysis of final } \\
\text { design. Reproducible copies not required. } \\
\text { No changes to the drawings may be } \\
\text { implemented after drawing approval without } \\
\text { written concurrence of the INL }\end{array}$ \\
\hline 412 & New and Unused & All material \\
\hline 450 & $\begin{array}{l}451,452,453,454,455,456 \\
\text { Suspect/counterfeit materials } \\
\end{array}$ & All applicable materials \\
\hline 521 & Right of Access & \\
\hline 532 & Source Inspection & $\begin{array}{l}\text { The INL reserves the right to witness any } \\
\text { inspections or testing }\end{array}$ \\
\hline 541 & Receiving Inspection & $\begin{array}{l}\text { 1. Inspect for damage } \\
\text { 2. Verify shipping container count } \\
\text { 3. Verify completion of core documents listed in } \\
\text { Vendor Data Schedule }\end{array}$ \\
\hline 723 & Inspection/Test Data & \\
\hline 731 & Procedure Qualification & $\begin{array}{l}\text { 1) Weld procedure for all applicable joint and } \\
\text { stud weld types }\end{array}$ \\
\hline
\end{tabular}




\begin{tabular}{|l|lll|}
\hline URANIUM PROTOTYPE GLOVEBOX & Identifier: & SPC-2954 & \\
AND FURNACE DESIGN AND BUILD & Revision: & 0 & \\
& Effective Date: & $01 / 19 / 21$ & Page: 38 of 50 \\
\hline
\end{tabular}

\begin{tabular}{|c|l|l|}
\hline ID & \multicolumn{1}{|c|}{ Description } & \multicolumn{1}{c|}{ Applicability } \\
\hline 732 & Personnel Qualification & $\begin{array}{l}\text { 1) Welder qualification for all applicable joint } \\
\text { and stud weld types } \\
\text { 2) Leak Tester (Level 2 or 3) }\end{array}$ \\
\hline 821 & $\begin{array}{l}\text { Operations \& Maintenance } \\
\text { Manual }\end{array}$ & \\
\hline 822 & Spare \& Replacement Parts & \\
\hline
\end{tabular}

\subsubsection{Calibration of Measuring and Test Equipment}

5.1.2.1 Calibration of test equipment shall be traceable to a nationally recognized standard as maintained by the National Institute of Standards and Technology (NIST). Calibration certificates shall be provided for torque wrenches, and helium leak standards.

5.1.2.2 The subcontractor is responsible for the performance of all inspections or tests specified herein unless otherwise specified by contract or purchase order. Inspection and testing of the glovebox shall be conducted in accordance with Table 2.

Table 2. Inspection and Testing.

\begin{tabular}{|l|l|l|}
\hline \multicolumn{1}{|c|}{ Test or Examination } & \multicolumn{1}{|c|}{ Test Paragraph } & \multicolumn{1}{c|}{ Applicable Requirements } \\
\hline $\begin{array}{l}\text { Visual and dimensional } \\
\text { inspection }\end{array}$ & 5.2 .2 & 4.1 .4 \\
\hline $\begin{array}{l}\text { Visual weld and weld stud } \\
\text { inspections }\end{array}$ & $5.2 .3,5.2 .3,5.2 .4$ & $4.1 .2,4.1 .2 .8$ \\
\hline Hoist load test & 5.3 .1 .2 & 3.3 .10 \\
\hline Structure proof test & 5.3 .1 .4 & 3.6 .4 \\
\hline Leak test & 5.3 .1 .5 & 3.6 .2 \\
\hline Operational testing & $5.3 .1 .3,5.3 .2$ & $3.3 .7,3.3 .8,3.4,3.5,3.6,3.7$ \\
\hline
\end{tabular}


URANIUM PROTOTYPE GLOVEBOX AND FURNACE DESIGN AND BUILD

$\begin{array}{lll}\text { Identifier: } & \text { SPC-2954 } \\ \text { Revision: } & 0 \\ \text { Effective Date: } & 01 / 19 / 21\end{array}$

Page: 39 of 50

5.1.2.3 The subcontractor shall submit for approval an inspection and test plan that outlines all tests and inspections to be performed to verify conformance to the requirements specified in Table 2. Inspection and test results shall be provided in accordance with the Vendor Data Schedule.

\subsection{Fabrication/Assembly Inspections, Tests and Hold Points}

5.2.1 Mandatory hold points include:

1. After completion of welding and weld inspections on structural stands and completion of initial fit and tack of first shell

2. After flatness inspection and prior to installation of viewing windows. INL approval of flatness inspection (See 4.1.4.5 and 5.2.2) prior to proceeding with window installation.

3. Prior to leak tests and operational test.

5.2.2 Visual and Dimensional Inspection. The gloveboxes shall be subjected to a visual and dimensional inspection prior to assembly to verify compliance with the specifications. Inspections shall include window frame flatness and surface finish of interior and sealing surfaces.

5.2.3 Visual Weld Examination. All welds shall be visually inspected in accordance with AGS-G006-2005 Sections 5.2.6, 5.2.8 and 5.2.11. In addition, welds on all interior or sealing surfaces of the glovebox shell shall be free of the following defects and conditions:

A. Slag or porosity

B. Cold laps in the deposited weld metal

C. Overlap of weld metal on the base metal

D. Undercutting

E. Depressions in welds below the base metal surface

F. Unfilled weld craters (shrinkage cavities)

G. Evidence of damage to the weld metal through oxidation; oxidation is defined as granulation or scaling of the metal surface that cannot be removed or restored to a bright metal by wire brushing

H. Weld splatter 
URANIUM PROTOTYPE GLOVEBOX AND FURNACE DESIGN AND BUILD

\begin{tabular}{|lll|} 
Identifier: & SPC-2954 & \\
Revision: & 0 & \\
Effective Date: & $01 / 19 / 21$ & Page: 40 of 50 \\
\hline
\end{tabular}

I. Arc burns or scars on the base metal caused by striking or dragging the welding arc across the base metal.

Fillet welds shall meet size requirements after grinding and finishing. Welded areas shall not be ground below the original material thickness. Defective areas may be reworked by re-welding and grinding smooth. After rework, welds shall be re-inspected per original requirements.

5.2.4 Weld Stud Visual Examination. All welds shall be visually inspected in accordance with AWS D1.6 Section 9. Visually inspect all stud welds for a full 360 degree flash. Torque and bend testing of studs are not required as stud welds are not structural in glovebox design. Studs that do not exhibit full 360 degree flash shall be torque tested in conformance with AWS D1.6 Figure 9.5 to the proof load torque level in Table 9.2. Acceptance criterion is no visible sign of failure.

\subsection{Post Assembly Inspections, Tests and Hold Points}

5.3.1 Mandatory hold points include:

5.3.1.1 Prior to leak tests and operational test.

5.3.1.2 Hoist Load Test. The hoist shall be load tested at $125 \%$ of the working load limit of 500 pounds. The load shall be suspended for 10 minutes. During this time, the hoist shall be moved within its limits of travel. Verify that load has not shifted and no damage has occurred to the glovebox.

5.3.1.3 Hoist Operability Test. The hoist shall be moved throughout its entire range of motion to ensure easy movement and no drifting once stopped. The electric operation of the hoist shall ensure that the electric stops operate properly.

5.3.1.4 Structure Proof Test. The assembled glovebox shall be proof tested in accordance with AGS-G006-2005 Section 4.20.2. Test pressure shall be ( + and -$) 5$ inches of water.

5.3.1.5 Leak Test. Leak test shall be performed in accordance with AGS-G006-2005 Section 4.20.3. Leak testing shall include a pressure decay and helium leak test. The subcontractor may, at its option, perform a bubble test on mechanical joints using a leak detection solution to eliminate gross leaks prior to performing leak tests.

Test conditions:

A. The glovebox shall be fully assembled and connected with airlock. 


$\begin{array}{lll}\text { Identifier: } & \text { SPC-2954 } \\ \text { Revision: } & 0 \\ \text { Effective Date: } & 01 / 19 / 21\end{array}$

Page: 41 of 50

B. The leak tests shall include all pressure control equipment and piping, the purification system, ventilation piping, interconnecting ductwork and all supply and exhaust tubing, piping, and valve joints.

C. CRL gloveport plugs shall be installed in the gloveports.

D. The subcontractor is responsible for plugging and capping all openings in the enclosure. The actual glovebox equipment shall be installed wherever possible.

E. The hoist shall be loaded to $125 \%$ of capacity during leak test.

F. The tests shall use a pressure relief device to preclude subjecting the enclosures to excess pressures.

\subsection{Positive Pressure Decay Test}

The positive pressure decay test shall be performed in accordance with AGS-G006-2005 Section 4.20.3.1 with the exception that the acceptance criterion for the pressure decay test is $0.05 \%$ of the glovebox volume per hour.

\subsection{Helium Leak Test}

Helium leak testing shall be performed in accordance with AGS-G006-2005

Section 4.20.3.2 and the following:

A. Leak test standards shall be calibrated. See Section 5.1.2.

B. Personnel performing leak testing shall be certified per the requirements of ASNT SNT-TC-1A. All tests shall be performed or witnessed by personnel holding either Level II or Level III certifications. All test reports shall be signed by the test performer and test witness.

C. Glovebox differential pressure of at least 4.0-iwg. 


\begin{tabular}{l|lll|} 
URANIUM PROTOTYPE GLOVEBOX & Identifier: & SPC-2954 & \\
AND FURNACE DESIGN AND BUILD & Revision: & 0 & \\
& Effective Date: & $01 / 19 / 21$ & Page: 42 of 50 \\
\hline
\end{tabular}
D. Glovebox atmosphere of at least $90 \%$ concentration of helium.
E. Measurements shall be performed with an instrument capable of detecting leaks of at least $1 \times 10^{-5} \mathrm{cc} / \mathrm{sec}$.

Acceptance Criterion: There shall be no detectable leakage (individual leaks) in any weld joint or mechanical seal greater than $1 \times 10^{-4} \mathrm{cc} / \mathrm{sec}$. Leaks in mechanical joints shall be identified and reworked or repaired until leakage in excess of the specified rate $\left(1 \times 10^{-4} \mathrm{cc} / \mathrm{sec}\right)$ is eliminated.

\section{Test results shall be provided in accordance with the Vendor Data Schedule.}

5.3.2 Glovebox Operational Testing. The subcontractor shall perform operational testing of the assembled glovebox system at the subcontractor's facility or a facility selected by the subcontractor. The subcontractor shall notify the INL at least 20 working days prior to beginning testing.

The operational testing of the glovebox pressure control systems shall demonstrate that the primary and secondary pressure control systems operate as specified to provide protection against the following failures or accidents:

- $\quad$ Primary pressure control including over and under pressure

- $\quad$ Loss of glove (verification of secondary pressure control valve actuation)

- $\quad$ Response to abnormal hi or low pressure

Additional operational testing shall include:

- $\quad$ Change-out of ventilation HEPA filters

- Verify airlock door operation and bag out chamber door function

- $\quad$ Ensure the atmosphere sampling monitors and alarms are operational

- $\quad$ Ensure proper function of airlock purging features

- $\quad$ Ensure proper operation of purification system

- $\quad$ The purification system Auto-Purge function operates 
URANIUM PROTOTYPE GLOVEBOX AND FURNACE DESIGN AND BUILD

$\begin{array}{ll}\text { Identifier: } & \text { SPC-2954 } \\ \text { Revision: } & 0 \\ \text { Effective Date: } & 01 / 19 / 21\end{array}$

Page: 43 of 50

- $\quad$ The purification system can reduce Oxygen levels below 5-ppm

- $\quad$ The purification system circulation rates are consistent with published data

- Hoist is operational and complies with specification

- $\quad$ Verify hook travel, speed control, and limits

- $\quad$ Verify trolley travel, end approaches, and limits

- $\quad$ Verify bridge travel, end approaches, and limits

- $\quad$ Verify $125 \%$ load test does not damage windows

- Electrical systems are operational

- $\quad$ Continuity and polarity check of all receptacles

- $\quad$ Lighting and dimming are operational

Test results from the operational test shall be provided in accordance with the Vendor Data Schedule.

\section{PREPARATION FOR DELIVERY}

\subsection{Packing and Packaging}

6.1.1 Preparation for Shipment. The subcontractor shall provide adequate protection for shipping the fabricated components to the INL without damage. Care shall be exercised to ensure that the surface finishes, cleanliness, dimensional stability, and overall integrity of the equipment achieved during fabrication are not impaired during shipment. The glovebox assembly shall be shipped in an enclosed, dedicated, air ride trailer. The delivery driver shall be a US citizen.

The intent is to minimize disassembly/reassembly of the leak tested glovebox assembly including airlock, purification system, and piping to the minimum necessary for shipment and transport within EFF. Where practical, original equipment manufacturer components and assemblies (e.g., pressure control equipment, monitoring equipment, purification system, and similar equipment) shall be remain installed in the glovebox assembly. All mechanical and electrical components not mounted to the glovebox chassis shall be packed or repackaged for shipment. Plugs or caps shall be installed on any open fittings or connections. Bubblers shall be drained and repackaged for shipment. 


\begin{tabular}{l|lll|} 
URANIUM PROTOTYPE GLOVEBOX & Identifier: & SPC-2954 \\
AND FURNACE DESIGN AND BUILD & Revision: & 0 & \\
& Effective Date: & $01 / 19 / 21$ & Page: 44 of 50 \\
\hline
\end{tabular}

The glovebox shall be wrapped in vinyl or cellophane sheet to provide protection from dirt and moisture during shipment. Appurtenances on the top and ends of the glovebox that exceed the height and length limits identified in INL drawings with casters installed, shall be removed. All other pipe, conduit, and wiring should remain assembled if possible. Components removed should be crated or mounted on pallets for ease of handling during shipment. (The subcontractor may, with the approval of the INL, use alternative shipping protection methods that the subcontractor has successfully used in the past.)

Components and assemblies not returned to original equipment manufacturer containers shall be anchored and braced if necessary, to prevent shifting or damage during transit. The subcontractor shall provide temporary marking of mating joints for ease of in-place assembly by the INL. An itemized packing list shall accompany the shipment.

6.1.2 Packaging of Windows. INL prefers the glovebox windows remain installed for shipping. However, if removed, exposed surfaces shall be covered with foam sheets to reduce the possibility of scratching the windows. If windows are removed from the enclosure, windows shall be crated by a $3 / 8$-in. minimum thickness plywood sheet to protect from damage. Any alternate substitute method proposed by the subcontractor shall be a proven method for shipping windows, and shall retain the capability of being easily removed. Glass-bearing crates shall be prominently marked.

Glove rings should remain mounted in the windows or may be repackaged in the original manufacturer's shipping container. If repackaged, all mounting and maintenance instructions for glove rings supplied by the manufacturer shall be shipped to the INL with the glove rings. The polypropylene plugs shall remain installed in the glove rings.

\subsubsection{OEM Equipment and Documentation}

All original equipment manufacturers' installation, operation, and maintenance documentation, schematics, installation and assembly instructions, wiring diagrams, or manuals shall be supplied to INL at the time of shipment. All OEM documentation shall be original and placed in binders as appropriate. Scanned and indexed electronic copies of all documentation are required. Refer to the Vendor Data Schedule.

The subcontractor is responsible for providing operating and maintenance instructions, schematics, wiring diagrams, panel directories, one-line diagrams, piping and instrumentation diagrams, or manuals for subcontractor-designed systems and equipment in accordance with INL Quality Clause 821. 


\begin{tabular}{l|lll|} 
URANIUM PROTOTYPE GLOVEBOX & Identifier: & SPC-2954 \\
AND FURNACE DESIGN AND BUILD & Revision: & 0 & \\
& Effective Date: & $01 / 19 / 21$ & Page: 45 of 50 \\
\hline
\end{tabular}

6.1.4 Installation and Assembly Instructions. The subcontractor shall provide, with the glovebox, written instructions for reassembly of the glovebox at the INL. The assembly instructions should include provisions or special instructions for the following, as appropriate:
A. Assembly of shells to stands
B. Window installation instructions
C. Hoist installation
D. Furnace installation
E. Purification system connection instructions
F. Pressure control system assembly instructions
G. Atmosphere monitoring system connection
H. Access panel(s)
I. Installation and filling of pressure relief bubblers
J. Electrical connections.

The instructions shall provide the recommended order for installation of various components and identify any precautions needed to prevent damage to the glovebox or equipment or potential safety hazards that may exist in assembly of the glovebox. The instructions shall identify bolting patterns and recommended torque values and sequences for windows, joints, access panels, and other bolt-in hardware. Torque values for gas fittings also shall be provided if applicable.

6.1.5 Spare Parts and Special Tools. The subcontractor shall provide a list of suggested spare parts in accordance with Quality Clause 822. The subcontractor also shall identify any special tools required for replacement of windows, glove rings, or other replaceable equipment. If special tools are required for assembly or window installation, a complete set of tools and instructions shall be provided with the glovebox and shall remain the property of INL. Lists and procedures shall be submitted in accordance with the Vendor Data Schedule. 


\begin{tabular}{l|lll|} 
URANIUM PROTOTYPE GLOVEBOX & Identifier: & SPC-2954 & \\
AND FURNACE DESIGN AND BUILD & Revision: & 0 & \\
& Effective Date: & $01 / 19 / 21$ & Page: 46 of 50 \\
\hline
\end{tabular}

\subsection{Marking and Handling}

6.2.1 Crates shall be marked with the contract number, the actual weight of the loaded crate, center of gravity of the crate, the assembly orientation in the crate, and the contents of the crate. Bulky items or pallets requiring movement by forklift or crane shall have the weight conspicuously identified or labeled. Handling and storage instructions shall be permanently marked on or attached to the shipping crate.

\subsection{Data Package}

6.3.1 All vendor data, installation/instruction manuals, calibration documentation, analyses, material certifications, or inspection documentation shall be placed in a marked binder. The binder shall be delivered to the INL in accordance with the provisions of the contract. Electronic copies of all documentation are requested. Scanned copies are acceptable if electronic originals are not available.

\section{SUPPLEMENTAL INFORMATION}

\subsection{Definitions}

The following definitions apply throughout this specification.

Assembly - For the purpose of this specification, assembly refers to the physical assembly of the gloveboxes, including all windows, glove rings, support structure, appurtenances, attachments, and auxiliary equipment/features provided by the subcontractor.

Glass Product Definitions - Refer to ASTM C 162.

Glovebox - A glovebox is defined as an enclosure with a controlled environment that provides a confinement boundary between the interior work area and the operator. The operations are performed through sealed glove openings for the protection of the worker, the environment, and/or the process.

Confinement Boundary - A physical barrier separating the interior environment from the exterior surroundings to protect the operator and exterior working area from all potentially contaminated operations conducted inside the glovebox. For most glovebox, the confinement boundary is comprised of the shell, the windows, and the glove ports with gloves. Also includes any circulation and exhaust ductwork.

INL - Idaho National Laboratory (INL), operated for the U.S. Department of Energy (DOE) by Battelle Energy Alliance, LLC (BEA). Contractual obligations are between Battelle Energy Alliance and the firm responsible for design and fabrication of the glovebox. 
URANIUM PROTOTYPE GLOVEBOX AND FURNACE DESIGN AND BUILD \begin{tabular}{lll} 
Identifier: & SPC-2954 \\
Revision: & 0 \\
Effective Date: & $01 / 19 / 21$ \\
\hline
\end{tabular}
Page: 47 of 50

Subcontractor - Refers to the fabricator or manufacturer (selected by Battelle Energy Alliance on behalf of INL) responsible for accomplishing the scope of work defined herein, including procurement, installation, and checkout of the auxiliary equipment specified herein.

Supplier - Refers to a subordinate vendor or source of supply for materials or equipment selected by the subcontractor and is responsible for delivery of materials and equipment to the subcontractor to accomplish the scope of work defined herein.

\subsection{Acronyms}

AGS American Glovebox Society

ANSI American National Standards Institute

ASHRAE American Society of Heating, Refrigeration, \& Air-Conditioning Engineers

ASME American Society of Mechanical Engineers

ASNT American Society for Nondestructive Testing

ASTM American Society of Testing and Materials

AWS American Welding Society

BEA Battelle Energy Alliance

CRL Central Research Laboratories

DOE Department of Energy

EFF Experimental Fuels Facility

GFE Government Furnished Equipment

HEPA high-efficiency particulate air

INL Idaho National Laboratory

MFC Materials and Fuels Complex

NEC National Electrical Code

NFPA National Fire Protection Association

NIST National Institute of Standards and Technology 


\begin{tabular}{|ll|ll|}
\hline $\begin{array}{l}\text { URANIUM PROTOTYPE GLOVEBOX } \\
\text { AND FURNACE DESIGN AND BUILD }\end{array}$ & $\begin{array}{l}\text { Identifier: } \\
\text { Revision: } \\
\text { Effective Date: }\end{array}$ & $\begin{array}{l}\text { SPC-2954 } \\
0\end{array}$ \\
$01 / 19 / 21$ & Page: 48 of 50 \\
\hline NPT & National Pipe Thread & \\
OCS & Operator Control Station & \\
PC & Performance Category \\
PLC & Programmable Logic Controller \\
ppm & parts per million \\
UPS & Uninterruptable Power Supply \\
VAC & Volts Alternating Current
\end{tabular}

\subsection{Equipment Manufacturers}

The following equipment manufacturers have been identified as potential sources of supply for equipment to be used in the fabrication of this glovebox. Refer to Step 3.1.4.

\subsubsection{Electrical Feedthroughs}

ISI Insulator Seal 6460 Parkland Drive Sarasota, FL 34243

Tel: $800-548-9509$ 941-751-2880

Fax: 941-751-3841 www.inslulatorseal.com

Pave Technology Company 2751 Thunderhawk Court Dayton, OH 45414-3451

Tel: $937-890-1100$

Fax. 937-890-5165 www.pavetechnologyco.com
Douglas Electrical Components 5 Middlebury Blvd Randolph, NJ 07869

Tel: 973-627-8230

Fax: 866-206-6916

www.douglaselectrical.com 
URANIUM PROTOTYPE GLOVEBOX AND FURNACE DESIGN AND BUILD
Identifier: $\quad$ SPC-2954

Revision: $\quad 0$

Effective Date: 01/19/21

\subsubsection{Vacuum Flange Fabricators}

MDC Vacuum Products Corporation 23842 Cabot Boulevard,

Hayward, CA 94545-1661

Tel: $800-443-8817$

Fax: 510-887-0626

http://www.mdevacuum.com

Kurt J. Lesker Company

1925 Route 51

Clairton, PA 15025-3681

Tel: $800-245-1656$

Fax: 412-384-2745

e-mail: salesus@lesker.com

http://www.lesker.com

\subsubsection{HEPA Filters}

Pall Microelectronics Corporation 2200 Northern Boulevard

East Hills, New York 11548-1289

Tel: $800-360-7255$

Fax: 516.625.3610

Matheson TRI-gas, Inc

6775 Central Ave

Newark, CA 94560

Tel: $510-793-2559$

http://www.mathesongas.com

Flanders Filters, Inc.

531 Flanders Filters Road

Washington, North Carolina 27889

Tel: 252-946-8081

Fax: 252-946-3425

http://www.flanders-csc.com
MKS Vacuum Technology

HPS ${ }^{\circledR}$ Products

5330 Sterling Drive

Boulder, CO 80301

Tel: 800-345-1967

http://www.mksinst.com

A\&N Corporation

707 Southwest 19th Avenue

Williston, Florida 32696

Tel: (800) FLANGE1

Fax: (352) 528-3441

http://www.ancorp.com

Nuclear Filter Technology

741 Corporate Circle, Suite R Golden, Colorado 80401

Tel: $\quad 303-384-9785$

Fax: 303-384-9579

http://www.nuclearfilter.com

Air Filters, Inc

8282 Warren Road

Houston, Texas 77040

Tel: $800-667-08563$

http://www.airfiltersusa.com

Camfil, M.C. Air Filtration

200 Creekside Dr

Washington, North Carolina 27889

Tel: 252-975-1141

http://www.camfil.com 


\begin{tabular}{l|lll|} 
URANIUM PROTOTYPE GLOVEBOX & Identifier: & SPC-2954 & \\
AND FURNACE DESIGN AND BUILD & Revision: & 0 & \\
& Effective Date: & $01 / 19 / 21$ & Page: 50 of 50 \\
\hline
\end{tabular}

8. APPENDICES

Appendix A, Parts List for the Uranium Prototype Glovebox

Appendix B, Casting Furnace Design 
URANIUM PROTOTYPE GLOVEBOX AND FURNACE DESIGN AND BUILD
Identifier:

Revision:

Effective Date: 01/19/21

0
SPC-2954

Page: A1 of A6

\section{Appendix A}

\section{Parts List for the Uranium Prototype Glovebox}

\begin{tabular}{|c|c|c|c|c|}
\hline Item & ID & Manufacturer & Part \# & Description/Function \\
\hline 1 & UPG-AE-136 & Vaisala & $\begin{array}{c}\text { DMT152- } \\
\text { B1DED1XA500A1A }\end{array}$ & Supplied with MBraun Purification Unit \\
\hline 2 & UPG-AE-137 & Ntron & SenzTx & Supplied with MBraun Purification Unit \\
\hline 3 & UPG-BLW-101 & MBraun & $\mathrm{N} / \mathrm{A}$ & Blower for cooler, GFE \\
\hline 4 & UPG-BLW-102 & MBraun & $\mathrm{N} / \mathrm{A}$ & Blower for cooler, GFE \\
\hline 5 & UPG-BLW-159 & MBraun & 9002832 & Supplied with MBraun Purification Unit \\
\hline 6 & UPG-BUB-101 & \multirow[t]{3}{*}{ MBraun } & \multirow[t]{3}{*}{8015676} & \multirow[t]{3}{*}{ Pressure/Vacuum Relief Bubbler, GFE } \\
\hline 7 & UPG-BUB-102 & & & \\
\hline 8 & UPG-BUB-103 & & & \\
\hline 9 & UPG-CMP-101 & MBraun & $\mathrm{N} / \mathrm{A}$ & Compressor for cooler, GFE \\
\hline 10 & UPG-CMP-102 & MBraun & $\mathrm{N} / \mathrm{A}$ & Compressor for cooler, GFE \\
\hline 11 & UPG-FIC-111 & King & 745-3P2-2344 & Flow control meter, 2-20cfm, valve upstream \\
\hline 12 & UPG-FIC-114 & $\mathrm{N} / \mathrm{A}$ & $\mathrm{N} / \mathrm{A}$ & Mounted on purification system \\
\hline 13 & UPG-FIC-130 & King & $\begin{array}{l}\text { 74C-108G061- } \\
323510\end{array}$ & Flow control meter, $0.3-2.4 \mathrm{cfh}$, valve upstream \\
\hline 14 & UPG-FIT-158 & IFM & SD2001 & Compressed Air Meter \\
\hline 15 & UPG-FLT-101 & Flanders & $\begin{array}{l}\text { 0-007-1-43-RF-NU- } \\
\text { 51-E3-Z14239 }\end{array}$ & HEPA filter, radial flow, 5 -in dia x 12.75-in lg \\
\hline 16 & UPG-FLT-102 & Flanders & $\begin{array}{c}\text { 0-007-1-43-RF-NU- } \\
51-E 3-Z 14239 \\
\end{array}$ & HEPA filter, radial flow, 5 -in dia x 12.75 -in lg \\
\hline 17 & UPG-FLT-115 & MBraun & & Supplied with MBraun Purification Unit \\
\hline 18 & UPG-FLT-119 & NUCFIL & 013 or 019 & Cartridge HEPA filter, 3/4-in NPSM, .02cfm@1iwg \\
\hline 19 & UPG-FLT-120 & Glaskleen & GLFPF3101SM4 & Cartridge HEPA filter, 1/4" Compression Seal \\
\hline 20 & UPG-FLT-124 & Glaskleen & GLFPF3101SM4 & Cartridge HEPA filter, $1 / 4$ " Compression Seal \\
\hline 21 & UPG-FLT-125 & Flanders & $\begin{array}{l}\text { X-007-D-15-N2- } \\
\text { NU-00-00-Z12310 } \\
\end{array}$ & $\begin{array}{l}\text { Cartridge HEPA filter, KF-25, 4-in Dia. X } 7.5 \text { in, } \\
18 \text { cfm @ } 1 " \text { iwg }\end{array}$ \\
\hline 22 & UPG-FLT-130 & Matheson & 6164P4FF & Cartridge HEPA filter, 1/4-inFNPT, 4cfm@10psi \\
\hline 23 & UPG-FLT-132 & NUCFIL & 013 or 019 & Cartridge HEPA filter, 3/4-in NPSM, .02cfm@1iwg \\
\hline 24 & UPG-FLT-133 & NUCFIL & 013 or 019 & Cartridge HEPA filter, 3/4-in NPSM, .02cfm@1iwg \\
\hline 25 & UPG-FLT-139 & Matheson & 6164P4FF & Cartridge HEPA filter, 1/4-inFNPT, 4cfm@10psi \\
\hline 26 & UPG-FLT-150 & Flanders & $\begin{array}{l}\text { 0-007-1-43-RF-NU- } \\
\text { 51-E3-Z11410 }\end{array}$ & $\begin{array}{l}\text { HEPA filter, radial flow, 5-in dia x 6.75-in lg, } \\
\text { 50cfm@1iwg }\end{array}$ \\
\hline 27 & UPG-FLT-154 & Flanders & $\begin{array}{l}\text { X-007-D-15-N2- } \\
\text { NU-00-00-Z12310 }\end{array}$ & $\begin{array}{l}\text { Cartridge HEPA Filter, KF-25, 4-in Dia. X 7.5-in, } \\
\qquad 18 \text { cfm @ } 1 \text { iwg }\end{array}$ \\
\hline 28 & UPG-FLT-160 & NUCFIL & 013 or 019 & Cartridge HEPA filter, 3/4-in NPSM, .02cfm@1iwg \\
\hline 29 & UPG-FLT-161 & NUCFIL & 013 or 019 & Cartridge HEPA filter, 3/4-in NPSM, .02cfm@1iwg \\
\hline
\end{tabular}


Idaho National Laboratory

\begin{tabular}{l|lll|} 
URANIUM PROTOTYPE GLOVEBOX & Identifier: & SPC-2954 & \\
AND FURNACE DESIGN AND BUILD & Revision: & 0 & \\
& Effective Date: & $01 / 19 / 21$ & Page: A2 of A6 \\
\hline
\end{tabular}

\begin{tabular}{|c|c|c|c|c|}
\hline Item & ID & Manufacturer & Part \# & Description/Function \\
\hline 30 & UPG-FLT-163 & NUCFIL & 013 or 019 & Cartridge HEPA filter, 3/4-in NPSM, .02cfm@1iwg \\
\hline 31 & UPG-FLT-178 & Flanders & $\begin{array}{l}\text { 0-007-D-15-N2-NU- } \\
00-00-Z 12310\end{array}$ & $\begin{array}{l}\text { Cartridge HEPA filter, KF-25, } \\
\text { 4-in Dia X 7.5-in, } 18 \text { cfm@1iwg }\end{array}$ \\
\hline 32 & UPG-HV-101 & Ideal Vacuum & P103575 & 2-in Ball Valve, KF-50 flange or EQUAL \\
\hline 33 & UPG-HV-102 & Ideal Vacuum & P103575 & 2-in Ball Valve, KF-50 Flange or EQUAL \\
\hline 34 & UPG-HV-104 & Swagelok & SS-45XF8 & 40G valve, 3-way, $1 / 2$ - in FNPT \\
\hline 35 & UPG-HV-105 & Swagelok & SS-45VF8-LLC-GR & 1/2-in FNPT, 2-way, series $40 \mathrm{G}$ valve, vented \\
\hline 36 & UPG-HV-106 & Swagelok & SS-45VF8-LLC-YW & 1/2-in FNPT, 2-way, series 40G valve, vented \\
\hline 37 & UPG-HV-107 & Swagelok & $\begin{array}{l}\text { SS-43GVF4-LLC- } \\
\text { BL }\end{array}$ & 1/4-in FNPT, 2-way, series $40 \mathrm{G}$ valve, vented \\
\hline 38 & UPG-HV-111 & Swagelok & SS-45F8 & 1/2-in FNPT, 2-way, series $40 G$ valve \\
\hline 39 & UPG-HV-114 & Swagelok & $\mathrm{N} / \mathrm{A}$ & On Purification system \\
\hline 40 & UPG-HV-117 & Swagelok & SS-43GXF4 & 1/4- in FNPT, 3-way, series 40G valve \\
\hline 41 & UPG-HV-118 & MBraun & $\mathrm{N} / \mathrm{A}$ & On Purification system exhaust stack \\
\hline 42 & UPG-HV-120 & Swagelok & SS-43GS4 & $\begin{array}{l}\text { Provided with MBraun control panel } \\
1 / 4 \text { "Tube Fitting, 2-way, } 40 \mathrm{G} \text { series ball valve }\end{array}$ \\
\hline 43 & UPG-HV-124 & Swagelok & SS-43GXF4 & $\begin{array}{l}\text { Provided with MBraun control panel } \\
\text { 1/4" FNPT, 3-way, series 40G valve }\end{array}$ \\
\hline 44 & UPG-HV-126 & Swagelok & SS-43GVCR4-A & $\begin{array}{l}\text { Provided with MBraun control panel } \\
\text { 1/4" angled, male VCR fitting, 2-way, } 40 \mathrm{G} \text { series } \\
\text { ball valve }\end{array}$ \\
\hline 46 & UPG-HV-127 & Swagelok & SS-43GVCR4-A & $\begin{array}{l}\text { Provided with MBraun control panel } \\
\text { 1/4" angled, male VCR fitting, 2-way, } 40 \mathrm{G} \text { series } \\
\text { ball valve }\end{array}$ \\
\hline 47 & UPG-HV-130 & Swagelok & SS-43GF4 & 1/4-in FNPT, 2-way, series 40G valve \\
\hline 48 & UPG-HV-132 & Swagelok & SS-43GF4 & 1/4-in FNPT, 2-way, series 40G valve \\
\hline 49 & UPG-HV-133 & Swagelok & SS-43GF4 & 1/4-in FNPT, 2-way, series 40G valve \\
\hline 50 & UPG-HV-134 & Swagelok & SS-43GXF4 & 1/4- in FNPT, 3-way, series 40G valve \\
\hline 51 & UPG-HV-139 & Swagelok & SS-43GF4 & 1/4-in FNPT, 2-way, series $40 G$ valve \\
\hline 52 & UPG-HV-150 & IdealVac & P103575 & 2-in Ball Valve, KF-50 OR EQUAL \\
\hline 53 & UPG-HV-152 & Swagelok & $\begin{array}{l}\text { SS-43GVF4-LLC- } \\
\text { BL }\end{array}$ & 1/4" FNPT, 2-way, series $40 \mathrm{G}$ valve, vented \\
\hline 54 & UPG-HV-155 & Swagelok & $\begin{array}{l}\text { SS-43GVF4-LLC- } \\
\text { BL }\end{array}$ & $1 / 4 "$ FNPT, 2-way, series $40 G$ valve, vented \\
\hline 55 & UPG-HV-156 & IdealVac & P103569 & 1-in Ball Valve, KF-25 OR EQUAL \\
\hline 56 & UPG-HV-157 & Swagelok & SS-43GXF4 & 1/4-in FNPT, 3-way, series 40G valve \\
\hline 57 & UPG-HV-160 & Swagelok & SS-43GXF4 & 1/4-in FNPT, 3-way, series $40 G$ valve \\
\hline 58 & UPG-HV-161 & Swagelok & SS-43GXF4 & 1/4-in FNPT, 3-way, series $40 \mathrm{G}$ valve \\
\hline 59 & UPG-HV-162 & Swagelok & SS-43GXS4 & 1/4- in tube fitting, 3-way, series $40 \mathrm{G}$ valve \\
\hline 60 & UPG-HV-163 & Swagelok & SS-43GXS4 & 1/4- in tube fitting, 3-way, series $40 \mathrm{G}$ valve \\
\hline
\end{tabular}


Idaho National Laboratory

\begin{tabular}{l|lll|} 
URANIUM PROTOTYPE GLOVEBOX & Identifier: & SPC-2954 & \\
AND FURNACE DESIGN AND BUILD & Revision: & 0 & \\
& Effective Date: & $01 / 19 / 21$ & Page: A3 of A6 \\
\hline
\end{tabular}

\begin{tabular}{|c|c|c|c|c|}
\hline Item & ID & Manufacturer & Part \# & Description/Function \\
\hline 61 & UPG-HV-178 & IdealVac & $\mathrm{P} 103569$ & 1-in Ball Valve, KF-25 OR EQUAL \\
\hline 62 & UPG-PCV-111 & Swagelok & $\begin{array}{c}\text { KLF1DFC411A300G } \\
\text { O }\end{array}$ & $\begin{array}{c}\text { Regulator, } 100 \text { psi input, 0-25 PSI output with } \\
\text { gauge }\end{array}$ \\
\hline 63 & UPG-PCV-120 & Swagelok & $\begin{array}{l}\text { KHF1EFC818A300 } \\
\text { J0 }\end{array}$ & $\begin{array}{l}\text { Regulator with Outlet Gage, High Flow, } 100 \text { psi } \\
\text { max input, } 0-50 \text { psi output range }\end{array}$ \\
\hline 64 & UPG-PI-124 & MBraun & & Supplied with MBraun Airlock/Purification Unit \\
\hline 65 & UPG-PI-157 & Dwyer & 2005 custom & Differential Pressure, negative scale 0 to -5 iwc \\
\hline 66 & UPG-PI-160A & Dwyer & 2001 custom & Differential Pressure, negative scale 0 to -1 iwc \\
\hline 67 & UPG-PI-160B & Dwyer & 2001 custom & Differential Pressure, negative scale 0 to -1 iwc \\
\hline 68 & UPG-PI-161A & Dwyer & 2001 custom & Differential Pressure, negative scale 0 to -1 iwc \\
\hline 69 & UPG-PI-161B & Dwyer & 2001 custom & Differential Pressure, negative scale 0 to -1 iwc \\
\hline 70 & UPG-PI-162 & Dwyer & 2001 custom & Differential Pressure, negative scale 0 to -1 iwc \\
\hline 71 & UPG-PMP-115 & MBraun & & Supplied with MBraun Purification Unit \\
\hline 72 & UPG-PMP-129 & MBraun & & Supplied with MBraun Purification Unit \\
\hline 73 & UPG-PRV-125 & MBraun & 7104198 & $\begin{array}{l}\text { Typical MBraun Relief Valve with associated KF- } \\
40 \text { extension }\end{array}$ \\
\hline 74 & UPG-PT-117 & MBraun & 4970009 & Supplied with MBraun Purification Unit \\
\hline 75 & UPG-PT-124A & MBraun & & Supplied with MBraun Airlock/Purification Unit \\
\hline 76 & UPG-PT-124B & MBraun & & Supplied with MBraun Airlock/Purification Unit \\
\hline 77 & UPG-PT-157 & Ashcroft & IXF024ST5IWL & $\begin{array}{l}\text { Provided with MBraun control panel } \\
\text { Differential Pressure Transmitter, }-5 \text { to } 5 \text { iwc, 4- } \\
\text { 20mA. }\end{array}$ \\
\hline 78 & UPG-PYV-120 & ASCO & $\begin{array}{l}8210 \mathrm{P} 087 \text { 12- } \\
\text { 24/DC }\end{array}$ & $\begin{array}{c}\text { Provided with MBraun control panel } \\
1 / 2 \text { " FNPT, } 2 \text { way, normally closed, } 24 \text { VDC } \\
\text { solenoid valve }\end{array}$ \\
\hline 79 & UPG-PYV-126 & ASCO & $\begin{array}{l}8210 \mathrm{P} 087 \text { 12- } \\
\text { 24/DC }\end{array}$ & $\begin{array}{c}\text { Provided with MBraun control panel } \\
1 / 2 \text { " FNPT, } 2 \text { way, normally closed, } 24 \text { VDC } \\
\text { solenoid valve }\end{array}$ \\
\hline 80 & UPG-PYV-127 & ASCO & $\begin{array}{l}8210 \mathrm{P} 087 \text { 12- } \\
\text { 24/DC }\end{array}$ & $\begin{array}{c}\text { Provided with MBraun control panel } \\
1 / 2 \text { " FNPT, } 2 \text { way, normally closed, } 24 \text { VDC } \\
\text { solenoid valve }\end{array}$ \\
\hline 81 & UPG-PYV-152 & $\begin{array}{l}\text { Swagelok } \\
\text { Monteur }\end{array}$ & $\begin{array}{c}\text { SS-65PST16T } \\
\text { SS-68TSW32T- } \\
\text { 20489-A150C5 with } \\
\text { 41N-E1S-S } \\
\end{array}$ & $\begin{array}{l}\text { Supplied with MBraun Purification Unit } \\
\text { Ball valve, 2-in, pneumatic actuated, KF-50 }\end{array}$ \\
\hline 82 & UPG-PYV-155 & VAT & & $\begin{array}{l}\text { Supplied with MBraun Purification Unit } \\
\text { Valve, KF-40, pneumatic actuated }\end{array}$ \\
\hline 83 & UPG-TE-101 & MBraun & $\mathrm{N} / \mathrm{A}$ & Thermocouple, Type K for cooler, GFE \\
\hline 84 & UPG-TE-102 & MBraun & $\mathrm{N} / \mathrm{A}$ & Thermocouple, Type $\mathrm{K}$ for cooler, GFE \\
\hline
\end{tabular}


Idaho National Laboratory

\begin{tabular}{l|lll|} 
URANIUM PROTOTYPE GLOVEBOX & Identifier: & SPC-2954 & \\
AND FURNACE DESIGN AND BUILD & Revision: & 0 & \\
& Effective Date: & $01 / 19 / 21$ & Page: A4 of A6 \\
\hline
\end{tabular}

\begin{tabular}{|c|c|c|c|c|}
\hline Item & ID & Manufacturer & Part \# & Description/Function \\
\hline \multicolumn{5}{|c|}{ FURNACE COMPONENTS } \\
\hline 1 & UPG-FIC-223 & King & 745-3P2-2344 & Flow control meter, 2-20cfm, valve upstream \\
\hline 2 & UPG-FLT-203 & Matheson & 6134-P8FF & Cartridge HEPA filter, 1/2-in FNPT \\
\hline 3 & UPG-FLT-225 & Matheson & 6164P4FF & Cartridge HEPA filter, 1/4-inFNPT, 4cfm@10psi \\
\hline 4 & UPG-FLT-241 & Matheson & 6134-P8FF & Cartridge HEPA filter, 1/2-in FNPT \\
\hline 5 & UPG-FLT-243 & Ajax-Tocco & & Supplied with Furnace Unit \\
\hline 6 & UPG-FLT-246 & Matheson & 6134-P8FF & Cartridge HEPA filter, 1/2-in FNPT \\
\hline 7 & UPG-FLT-251 & Matheson & 6134-P8FF & Cartridge HEPA filter, 1/2-in FNPT \\
\hline 8 & UPG-FLT-270 & NUCFIL & 013 or 019 & Cartridge HEPA filter, 3/4-in NPSM, .02cfm@1iwg \\
\hline 9 & UPG-FLT-279 & NUCFIL & 013 or 019 & Cartridge HEPA filter, 3/4-in NPSM, .02cfm@1iwg \\
\hline 10 & UPG-FUR-205 & Ajax-Tocco & & Supplied with Furnace Unit \\
\hline 11 & UPG-HV-201 & Swagelok & SS-45VF8-LLC-GR & 1/2-in FNPT, 2-way, series 40G valve, vented \\
\hline 12 & UPG-HV-202 & Swagelok & SS-45VF8-LLC-GR & 1/2-in FNPT, 2-way, series 40G valve, vented \\
\hline 13 & UPG-HV-203 & Swagelok & SS-45VF8-LLC-GR & 1/2-in FNPT, 2-way, series 40G valve, vented \\
\hline 14 & UPG-HV-204 & Swagelok & SS-43GXF4 & 1/4-in FNPT, 3-way, series $40 G$ valve \\
\hline 15 & UPG-HV-221 & Swagelok & SS-45VF8-LLC-GR & 1/2-in FNPT, 2-way, series 40G valve, vented \\
\hline 16 & UPG-HV-225 & Swagelok & SS-43GF4 & 1/4-in FNPT, 2-way, series $40 G$ valve \\
\hline 17 & UPG-HV-226 & Swagelok & SS-43GS4 & 1/4-in tube fitting, 2 -way, series $40 G$ valve \\
\hline 18 & UPG-HV-227 & Swagelok & SS-43GS4 & 1/4-in tube fitting, 2-way, series $40 \mathrm{G}$ valve \\
\hline 19 & UPG-HV-240 & Swagelok & SS-43GS8 & 1/2-in tube fitting, 2 -way, series $40 \mathrm{G}$ valve \\
\hline 20 & UPG-HV-241 & Swagelok & SS-43GS8 & 1/2-in tube fitting, 2 -way, series $40 G$ valve \\
\hline 21 & UPG-HV-243 & Swagelok & SS-43GS8 & 1/2-in tube fitting, 2 -way, series $40 \mathrm{G}$ valve \\
\hline 22 & UPG-HV-245 & Swagelok & SS-43GS8 & 1/2-in tube fitting, 2 -way, series $40 \mathrm{G}$ valve \\
\hline 23 & UPG-HV-246 & Swagelok & SS-43GS8 & 1/2-in tube fitting, 2 -way, series $40 G$ valve \\
\hline 24 & UPG-HV-247 & Swagelok & SS-43GS8 & 1/2-in tube fitting, 2-way, series $40 G$ valve \\
\hline 25 & UPG-HV-250 & Swagelok & SS-43GF8 & 1/2-in FNPT, 2-way, series $40 G$ valve \\
\hline 26 & UPG-HV-252 & Swagelok & SS-43GF4 & 1/4-in FNPT, 2-way, series 40G valve \\
\hline 27 & UPG-HV-253 & Swagelok & SS-43GF8 & 1/2-in FNPT, 2-way, series 40G valve \\
\hline 28 & UPG-HV-254 & Swagelok & SS-43GF8 & 1/2-in FNPT, 2-way, series $40 G$ valve \\
\hline 29 & UPG-HV-270 & Swagelok & SS-43GF4 & 1/4-in FNPT, 2-way, series 40G valve \\
\hline 30 & UPG-HV-279 & Swagelok & SS-43GF4 & 1/4-in FNPT, 2-way, series $40 G$ valve \\
\hline 31 & UPG-PCV-201 & Swagelok & $\begin{array}{l}\text { KHF1EFC818A300 } \\
\text { J0 }\end{array}$ & $\begin{array}{l}\text { Regulator with Outlet Gage, High Flow, } 100 \text { psi } \\
\text { max input, } 0-50 \text { psi output range }\end{array}$ \\
\hline 32 & UPG-PCV-222 & Swagelok & $\begin{array}{l}\text { KHF1EFC818A300 } \\
\text { J0 }\end{array}$ & $\begin{array}{l}\text { Regulator with Outlet Gage, High Flow, } 100 \text { psi } \\
\text { max input, } 0-50 \text { psi output range }\end{array}$ \\
\hline 33 & UPG-PCV-242 & Ajax-Tocco & & Supplied with Furnace Unit \\
\hline 34 & UPG-PCV-247 & Ajax-Tocco & & Supplied with Furnace Unit \\
\hline 35 & UPG-PI-204 & Ajax-Tocco & & Supplied with Furnace Unit \\
\hline 36 & UPG-PMP-243 & Ajax-Tocco & & Supplied with Furnace Unit \\
\hline
\end{tabular}


Idaho National Laboratory

URANIUM PROTOTYPE GLOVEBOX AND FURNACE DESIGN AND BUILD

Identifier: SPC-2954

Revision: $\quad 0$

Effective Date: $01 / 19 / 21$

Page: A5 of A6

\begin{tabular}{|c|c|c|c|c|}
\hline Item & ID & Manufacturer & Part \# & Description/Function \\
\hline 37 & UPG-PSV-204 & Ajax-Tocco & & Supplied with Furnace Unit \\
\hline 38 & UPG-PSV-224 & Ajax-Tocco & & Supplied with Furnace Unit \\
\hline 39 & UPG-PT-204 & Ajax-Tocco & & Supplied with Furnace Unit \\
\hline 40 & UPG-PT-205 & Ajax-Tocco & & Supplied with Furnace Unit \\
\hline 41 & UPG-PYV-201 & Ajax-Tocco & & Supplied with Furnace Unit \\
\hline 42 & UPG-PYV-202 & Ajax-Tocco & & Supplied with Furnace Unit \\
\hline 43 & UPG-PYV-205 & Ajax-Tocco & & Supplied with Furnace Unit \\
\hline 44 & UPG-PYV-226 & Ajax-Tocco & & Supplied with Furnace Unit \\
\hline 45 & UPG-PYV-227 & Ajax-Tocco & & Supplied with Furnace Unit \\
\hline 46 & UPG-PYV-240 & Ajax-Tocco & & Supplied with Furnace Unit \\
\hline 47 & UPG-PYV-242 & Ajax-Tocco & Supplied with Furnace Unit \\
\hline 48 & UPG-PYV-245 & Ajax-Tocco & Supplied with Furnace Unit \\
\hline 49 & UPG-PYV-247 & Ajax-Tocco & & Supplied with Furnace Unit \\
\hline 50 & UPG-PYV-252 & Ajax-Tocco & & Supplied with Furnace Unit \\
\hline 51 & UPG-TK-204 & Ajax-Tocco & & \\
\hline
\end{tabular}


INTENTIONALLY BLANK 


\begin{tabular}{l|lll|} 
URANIUM PROTOTYPE GLOVEBOX & Identifier: & SPC-2954 & \\
AND FURNACE DESIGN AND BUILD & Revision: & 0 & \\
& Effective Date: & $01 / 19 / 21$ & Page: B1 of B51 \\
\hline
\end{tabular}

\section{Appendix B}

\section{Casting Furnace Design}

\section{CONTENTS}

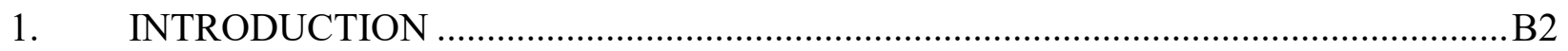

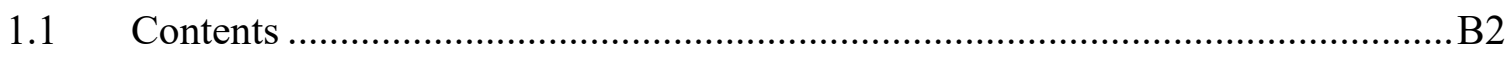

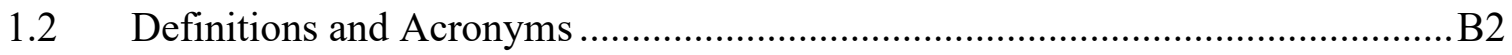

2. CASTING FURNACE FUNCTIONAL AND OPERATIONAL REQUIREMENTS ....B4

2.1 General System Configuration.............................................................. B4

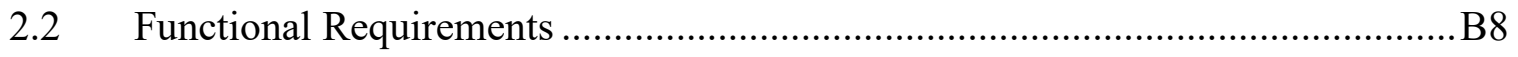

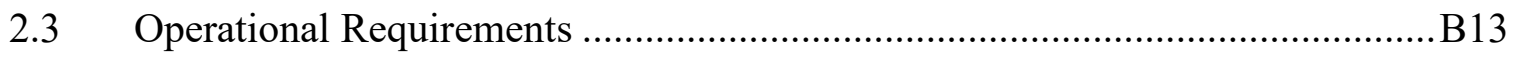

2.4 Owner Specified Technical Requirements.................................................. B31

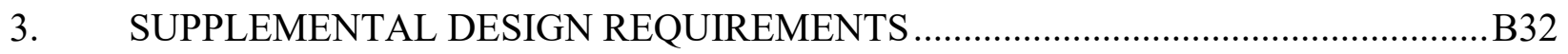

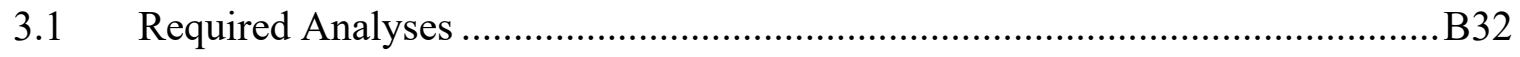

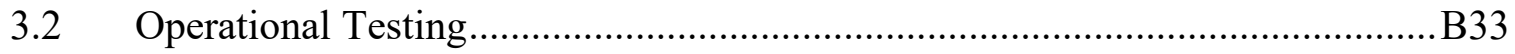

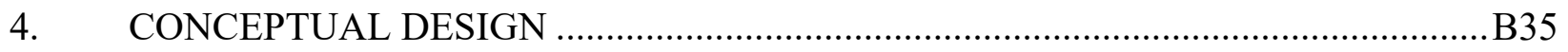

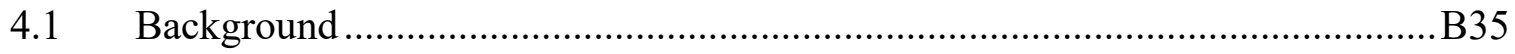

4.2 General Furnace Conceptual Design ......................................................... 36

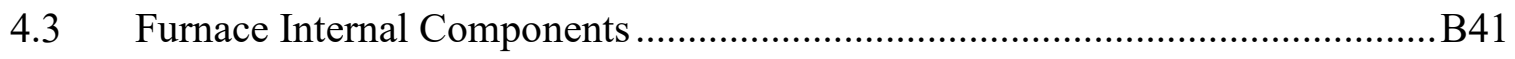

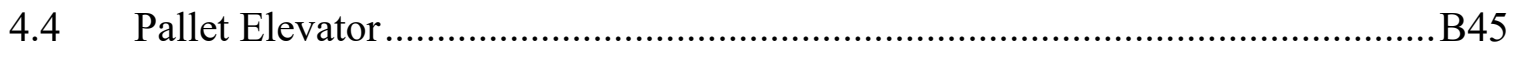

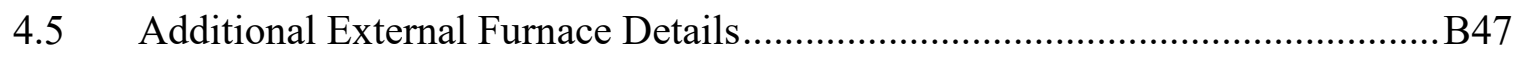

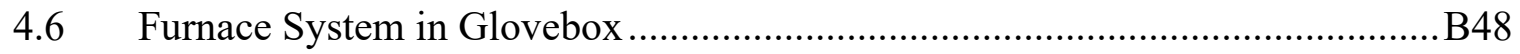

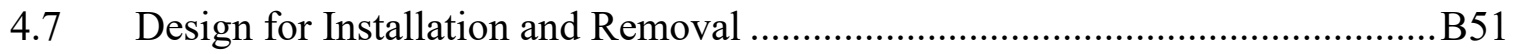


URANIUM PROTOTYPE GLOVEBOX AND FURNACE DESIGN AND BUILD

\begin{tabular}{|lll|} 
Identifier: & SPC-2954 \\
Revision: & 0 & \\
Effective Date: & $01 / 19 / 21$ & Page: B2 of B51 \\
\hline
\end{tabular}

\section{INTRODUCTION}

\subsection{Contents}

This Appendix provides requirements pertinent to the casting furnace system design for the VTR Fuel Casting System. The casting furnace system will include the casting furnaces, casting pressure system, casting vacuum systems, electrical power and controls, and all supporting fluid systems necessary to operate the casting furnace and perform injection casting operations.

For this prototype glovebox only one furnace system is required. However, all design considerations for the casting system shall take into account the operation of two furnaces. For example, the control systems shall be set up to allow for the addition of a second furnace and accumulator.

\subsection{Definitions and Acronyms}

The following definitions and acronyms are used throughout this document.

- $\quad$ DOE - Department of Energy.

- $\quad$ Casting Alloy - The mixed metal alloy used in the furnace to cast fuel slugs.

- $\quad$ Confinement Barrier/Boundary - The boundary separating different confinement zones.

- $\quad$ Confinement Zone - Confinement zones are areas established in a nuclear or radiological facility that have different potentials for experiencing airborne radioactive contamination. Confinement zones are typically designated as Primary, Secondary or Tertiary Confinement Zones. See the DOE Air Cleaning Handbook for more information.

- Criticality - "nuclear criticality" where sufficient fissile material is collected under the proper conditions and geometry to create a selfsustaining fission reaction.

- Crucible - The "cup" in that the feedstock is melted as part of the casting operation.

- $\quad$ FMF - Fuel Manufacturing Facility

- $\quad$ Feedstock - Materials that will be received into the system to create the casting alloy. This may consist of pre-mixed alloy, or elemental materials that would be mixed and homogenized in the furnace upon melting. 
- $\quad$ Casting Heel (or simply "Heel") - residual casting alloy and scrap remaining in the crucible after the casting process has been completed.

- $\quad$ HEPA - High Efficiency Particulate Air

- $\quad$ INL - Idaho National Laboratory (Also referred to herein as "the Laboratory".

- $\quad$ Molds - The individual glass or quartz tubes into which the alloy will be cast into slugs.

- $\quad$ Melt - The molten casting alloy.

- $\quad$ Pallet - The combination of a pallet frame and molds that is used for a single casting operation.

- $\quad$ Pallet Frame - A frame that is installed into the furnace and that holds an array of individual molds through the casting process.

- $\quad$ Pallet Elevator - The part of the furnace that holds the pallet, and that allows the pallet to be inserted into the melt and then withdrawn after casting.

- $\quad$ Primary Confinement Zone - Area where high levels of airborne radiological contamination are expected during normal operations.

- Primary furnace/accumulator system - This includes the furnaces, accumulator tanks, and the piping systems that connect them.

- $\quad$ Slugs - Cast elements produced by the injection casting process

- $\quad$ Secondary Confinement Zone - Area where high levels of airborne radiological contamination could be generated during normal operations or as a result of a breach of a primary confinement barrier.

- $\quad$ Susceptor - The material that couples to the magnetic field created by the induction furnace, and in which heat is thereby generated. The crucible and casting alloy may form part or all of the susceptor.

- $\quad$ Suspect Exhaust - Ventilation systems that service primary and secondary confinement areas and in which airborne radiological contamination does or could occur.

- $\quad$ Tertiary Confinement Zone - Area where airborne contamination is not expected during normal facility operations. Secondary and tertiary boundaries may be common, as in a single-structure envelope.

- $\quad$ VTR - Versatile Test Reactor 


\begin{tabular}{l|lll|} 
URANIUM PROTOTYPE GLOVEBOX & Identifier: & SPC-2954 & \\
AND FURNACE DESIGN AND BUILD & Revision: & 0 & \\
& Effective Date: & $01 / 19 / 21$ & Page: B4 of B51 \\
\hline
\end{tabular}

\section{CASTING FURNACE FUNCTIONAL AND OPERATIONAL REQUIREMENTS}

\section{Requirements and inputs within this section are labeled as follows:}

REQUIREMENT - Requirements with which the design must comply.

DESIRED - Requirements with which the design should comply. These requirements may be waived by INL if determined to not be practically achievable.

INFO - Information that is important to the design effort, but does not constitute a requirement.

BASIS- Most requirements are followed by a section labeled "BASIS". These sections provide information for the designer that is intended to assist in help in understanding the reason for the requirement and provide some background in explaining the requirement. BASIS sections are not intended to include requirements and are not considered binding upon the designer.

\subsection{General System Configuration}

2.1.1 INFO - The anticipated configuration of the VTR Casting System is shown in the conceptual design described in Section 4. The conceptual design is informational in nature and is not binding on the designer.

2.1.2 INFO - The Primary Confinement Boundary for the casting furnace system is comprised of the glovebox pressure boundary, furnace shells, accumulator vessel shells and gas piping/tubing systems up to the first HEPA filter outside these boundaries.

2.1.3 INFO - The following utilities are available in the Facility.

- $\quad$ Suspect Exhaust (Radiological)

- $\quad$ Argon Gas - 80-100 psig

- $\quad$ Instrument Air - 75-100 psig

- $\quad$ AC Power (normal)- 480V, 3PH, $60 \mathrm{~Hz}$.

- $\quad$ AC Power (normal) - 120/208V, 3PH, $60 \mathrm{~Hz}$.

- $\quad$ AC Power (standby) - 120/208V, 3PH, $60 \mathrm{~Hz}$ 
- $\quad$ Cooling water - available on a limited basis due to use by other equipment. Additional chillers can be added based on furnace, power supply and other system requirements

2.1.4 INFO - Injection Casting Process Description (conceptual) - The following process description is based on the processes previously used at INL for injection casting. See Section 4 for illustrations of the conceptual furnace layout and operation.

- The pallet elevator is removed from the furnace.

- $\quad$ Casting alloy is placed into the crucible and the crucible is placed into the furnace.

- $\quad$ The pallet is connected to the pallet elevator and the pallet elevator is re-installed into the furnace. The pallet cooling argon supply is connected to the pallet elevator. Pallet power and instrumentation/control (I\&C) wiring is connected.

- The furnace thermal shutters are closed.

- $\quad$ The furnace is evacuated to $\sim 50$ milliTorr and checked for leakage. Any leakage is corrected.

- $\quad$ Furnace pressure is increased to a set heating pressure with argon gas. Heating pressure will range from a very rough vacuum (400 Torr) to a positive pressure up to $30 \mathrm{psig}$ (42.2 psia). Current INL casting practice is to maintain a pressure of approximately 450 Torr to suppress evaporation of volatile elements during heating. Based on further research it has been identified that pressures of 15-30 psig argon were used in some furnaces in the FCF facility to suppress coil shorting due to "corona" effects, particularly at higher frequency and coil voltage.

- A pressure accumulator tank is charged to the necessary pressure ( $\sim 30 \mathrm{psig}$ ) to provide the desired casting pressure in the furnace during injection casting ( $\sim 16 \mathrm{psig})$.

- $\quad$ Furnace heating commences. The crucible and contents are heated to melt the casting alloy. Furnace pressure is maintained at a heating pressure between 400 Torr absolute and 30 psig to suppress volatilization of trace materials in the fuel alloy.

- When the casting temperature is reached, the furnace will remain at temperature for a specified period to allow for mixing of the alloy ( $\sim 30$ minutes) 


\begin{tabular}{l|lll|} 
URANIUM PROTOTYPE GLOVEBOX & Identifier: & SPC-2954 & \\
AND FURNACE DESIGN AND BUILD & Revision: & 0 & \\
& Effective Date: & $01 / 19 / 21$ & Page: B6 of B51 \\
\hline
\end{tabular}

- $\quad$ The furnace pressure is reduced to approximately less than 1Torr absolute.

- $\quad$ Furnace power is secured.

- $\quad$ The thermal shutters are opened. (They may be opened earlier if needed to pre-heat the molds).

- The pallet elevator lowers the pallet down to lower the molds into the melt.

- $\quad$ The fast-acting ball valve between the accumulator tank and furnace is rapidly opened to pressurize the furnace and force the melt into the molds.

- Mold cooling argon flow is initiated. The furnace is vented to maintain a positive pressure in the furnace $(\sim 5-15 \mathrm{psig})$ as the molds cool.

- $\quad$ Once the melt has cooled sufficiently (just above the cast material solidus temperature), the pallet elevator withdraws the pallet upward from the crucible.

- $\quad$ Thermal shutters are closed.

- $\quad$ Once sufficiently cooled, the pallet elevator and pallet are removed from the furnace.

- $\quad$ The pallet and filled molds are disconnected from the elevator and transferred to the demolding glovebox.

- $\quad$ The crucible with remaining casting heel is removed.

- $\quad$ The pallet elevator is replaced on the furnace. 
Identifier: $\quad$ SPC-2954

Revision: $\quad 0$

Effective Date: $01 / 19 / 21$

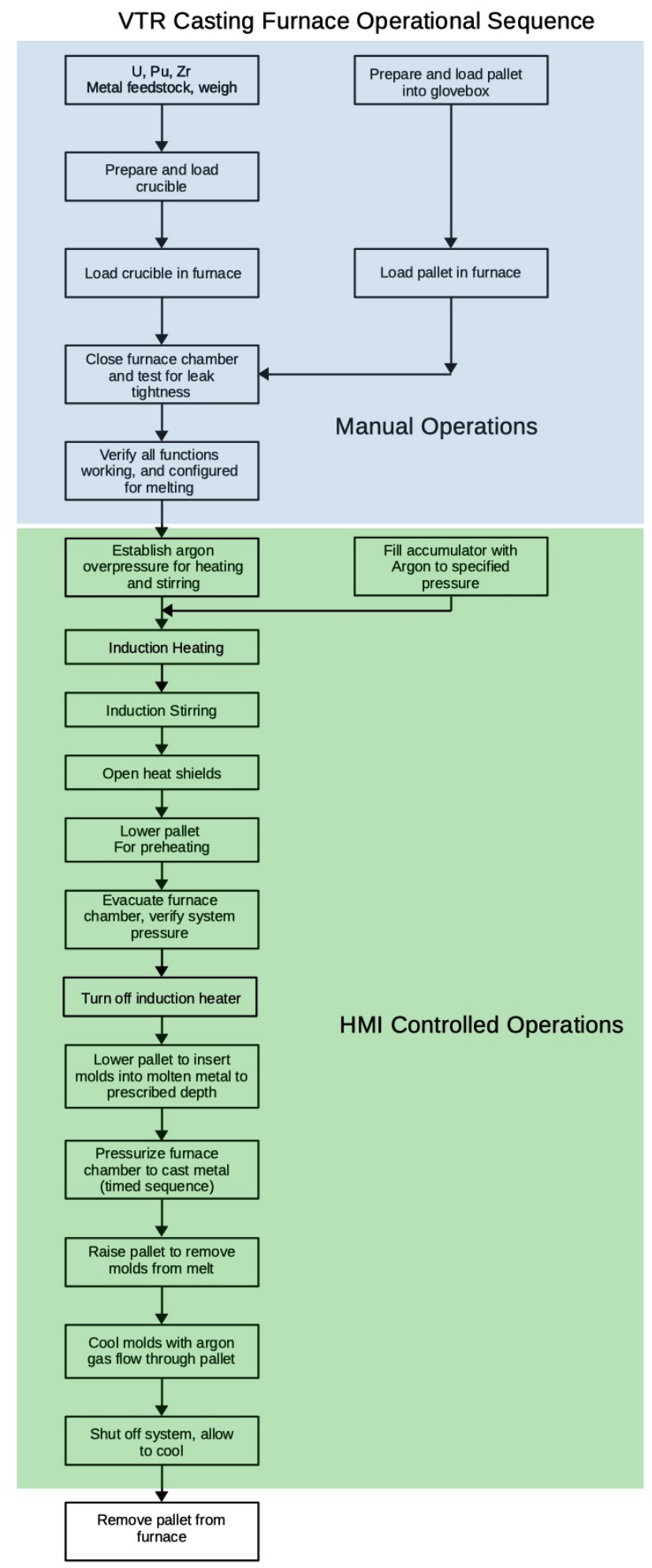

Figure 1. Operational Sequence for Casting Process. 


\begin{tabular}{l|lll|} 
URANIUM PROTOTYPE GLOVEBOX & Identifier: & SPC-2954 & \\
AND FURNACE DESIGN AND BUILD & Revision: & 0 & \\
& Effective Date: & $01 / 19 / 21$ & Page: B8 of B51 \\
\hline
\end{tabular}

\subsection{Functional Requirements}

\subsubsection{General Casting System Operation}

2.2.1.1 REQUIREMENT - The furnace system will be an induction heated design and will injection-cast molten fuel alloy into an array of long quartz-glass molds (the "Pallet"). The conceptual process is described in Section 4.

BASIS - Basic purpose of the system

2.2.1.2 REQUIREMENT - The furnace design for this project shall be capable of injection casting an alloy consisting $10 \%$ zirconium (Zr) - 90\% uranium (U) alloy by weight. Alloys may be provided as pre-mixed alloy or unmixed elemental pieces. Development and surrogate testing of this alloy and other alloys will generally be of lower densities, down to $8.96 \mathrm{~g} / \mathrm{cm}^{3}$ (copper). Casting mass of surrogate alloys would be reduced as required to provide the same maximum volume of alloy as for the design alloy. The VTR casting process will cast an alloy of $20 \%$ Plutonium $(\mathrm{Pu})$ 10\%Zirconium (Zr)-Uranium (U) alloy by weight. Density of this alloy at liquidus is estimated as $13.7 \mathrm{~g} / \mathrm{cm}^{3}$. The furnace design shall be able to cast both the U-Zr alloy and $\mathrm{Pu}-\mathrm{U}-\mathrm{Zr}$ alloy.

BASIS - This material has been identified as the reference fuel alloy for conceptual design and cost estimated for the VTR and is therefore the required casting material for the intended end-use (developmental testing). It is anticipated that initial process development will be performed with alloys that do not contain Pu to minimize the radiological hazards associated with process development.

\subsubsection{REQUIREMENT - The furnace shall use induction} stirring to mix the melt alloy and ensure homogenization of the alloy.

BASIS - Alloy will be typically be charged into the furnace as discrete elemental pieces. The alloy must be mixed to obtain a homogenous melt. Previous INL experience with mechanical stirring devices (typically tantalum stirring rods) has not been successful with U-Zr alloy at the anticipated temperatures due to the tendency of these devices to dissolve into the alloy. 
URANIUM PROTOTYPE GLOVEBOX AND FURNACE DESIGN AND BUILD

$\begin{array}{ll}\text { Identifier: } & \text { SPC-2954 } \\ \text { Revision: } & 0 \\ \text { Effective Date: } & 01 / 19 / 21\end{array}$

Page: B9 of B51

2.2.1.4

REQUIREMENT - The atmosphere in the primary furnace/accumulator system will be dry purified argon gas.

BASIS - Argon gas is used in casting facilities at INL to prevent oxidation of casting alloys. It also reduces the potential for fire, as finely divided casting alloy and dross may be pyrophoric.

2.2.1.5 REQUIREMENT - All equipment inside the glovebox will operate in a high purity argon environment.

BASIS - A high purity argon environment is maintained inside the glovebox to protect the feedstock and fuel alloy from oxidation. Due to the extremely low oxygen and moisture content, some components may be experience deleterious effects. For instance, standard motor brushes can experience high wear, and galling for some material couples may be enhanced.

2.2.1.6 REQUIREMENT - Thermal shutters will be provided between the crucible and the elevated mold pallet to minimize radiant heat transfer into the molds prior to casting. The shutters shall open to allow the pallet to be dipped into the crucible for casting. Shutters may also be required to open for viewing the melt.

BASIS - Shutters will limit the radiant heating of the pallets and upper sections of the furnace. Previous INL experience has demonstrated the necessity of controlling heat transfer into the pallets and furnace top.

2.2.1.7 REQUIREMENT - Components and equipment located inside the glovebox shall be designed and situated to facilitate operation in the glovebox environment. As a minimum, the following requirements shall be met:

- Connectors, fittings and equipment inside the glovebox shall be visible and accessible to an operator at a glove station using simple hand tools.

- $\quad$ Frequently operated connectors and fittings, such as the pallet elevator flange, shall incorporate features such as guide pins to simplify operation. Where the potential exists for fasteners or other components to fall into areas where removal would be difficult (such as into the furnace), those components shall 


$\begin{array}{lll}\text { Identifier: } & \text { SPC-2954 } \\ \text { Revision: } & 0 \\ \text { Effective Date: } & 01 / 19 / 21\end{array}$

Page: B10 of B51

either be captive or be provided with lanyards. INL can provide examples of captive fastener designs used in remotely operated systems.

- Connection and disconnection of the pallet from the pallet elevator shall be designed such that the operation can be accomplished in no more than 30 seconds.

- $\quad$ For some operations it may not be practical to provide visibility and/or direct access. For these operations, special tools and/or viewing equipment will be provided.

BASIS - Glovebox operations are significantly more difficult than operations on equipment that is directly accessible. The difficulties associated with the glovebox environment must be carefully considered in design of equipment.

2.2.1.8 REQUIREMENT - Argon cooling gas will be directed through the mold area after casting to cool the filled molds. Argon gas shall be delivered through the mold pallet.

BASIS - INL has found that provision of cooling gas into the mold area both improves the quality of the produced castings and shortens the time required for the furnace to cool such that it can be opened for extraction of the cast items. INL furnace designs typically include a service gas line to the pallet elevator and introduce argon through the central post of the pallet.

\subsubsection{Confinement Boundary Requirements}

2.2.2.1 REQUIREMENT - Mechanical joints (static) that are part of the radiological confinement boundary shall be high performance seals that are designed to allow in-place testing for leakage. Examples include Swagelok VCR for small diameter tubing, and Conflat (CF) vacuum flanges for larger diameter joints. For flanges or seals for which the above types of seals are not suitable due to size, configuration or pressure/vacuum capability (such as the flange that will seal the furnace shell to the glovebox floor), use of an engineered double O-ring seal that can be tested for leakage is acceptable. O-ring materials for engineered seals shall be chosen for high temperature capability and long service life. 


$\begin{array}{lll}\text { Identifier: } & \text { SPC-2954 } \\ \text { Revision: } & 0 \\ \text { Effective Date: } & 01 / 19 / 21\end{array}$

Page: B11 of B51

DuPont Kalrez ${ }^{\circledR}$ perflouroelastomer or equivalent is recommended.

BASIS - The integrity of the confinement boundary is important for the protection of the workers. Use of these types of mechanical joints provides greater confidence of performance and allows periodic helium leak testing to ensure that the integrity of the confinement boundary is maintained.

2.2.2.2 REQUIRED - Mechanical joints and seals (such as valve packing seals) that are part of the primary furnace/accumulator system shall be located inside the primary confinement boundary.

BASIS - This system is anticipated to contain high radiological contamination levels. This system includes the most frequently disassembled mechanical joints and a number of frequently operated mechanical seals. This system also subject to significant pressure and temperature variation during service. Because of these factors, this system has the highest risk for experiencing leakage of radiological materials.

2.2.2.3 REQUIREMENT - The furnace shall be designed to capture and solidify the melted fuel material in the event of a crucible failure. Material shall be directed to a removable catch basin designed to collect the material and allow it to solidify. The following requirements will be met in case of crucible failure.

- $\quad$ The catch basin must contain the melt until and after it solidifies. UNDER NO CIRCUMSTANCES may the melt material contact the furnace pressure/confinement boundary.

- $\quad$ The catch basin shall be designed such that the solidified melt may be re-sized into individual pieces that will fit into a 4-inch diameter $\mathrm{x} 4.5$ inch container.

- $\quad$ The catch basin shall be designed to be removed from the furnace into the glovebox by an operator at a glove station after it captures the melted fuel. 


$\begin{array}{lll}\text { Identifier: } & \text { SPC-2954 } \\ \text { Revision: } & 0 \\ \text { Effective Date: } & 01 / 19 / 21\end{array}$

Page: B12 of B51

BASIS - Some casting furnaces at INL have experienced failure of crucibles during melting. Above a temperature of approximately $800^{\circ} \mathrm{C}$, molten fuel alloy will rapidly attack any ferrous material. Unless collected, this could present a severe hazard to the primary confinement boundary.

To remove a frozen melt from the glovebox, the melt must be broken into sections that may be placed into a container of about 4 inches inside diameter, and 4.5 inches tall. The frozen melt should be collected in a geometry that facilitates size reduction for placement into a series of these containers.

2.2.2.4 REQUIREMENT - The use of water as a cooling media is not allowed inside the primary confinement boundary (use of water cooled induction coils is not allowed). However, water may be used for cooling external to the confinement boundary. Water cooling features shall be designed such that penetration of the primary confinement boundary due to corrosion, thermal fatigue cracks or other processes is not credible (i.e., the primary confinement boundary should not be used as a wetted surface in a water cooling system).

BASIS - While introduction of water into the melt is highly unlikely, the potential consequences (steam overpressure or explosion, material reaction, etc.) could be severe. INL safety personnel have determined that this potential, while remote, is unacceptable. Water introduction into the glovebox environment also presents several risks (such as reaction with the melt alloy or scrap) that are not acceptable.

Water cooling outside of the primary confinement boundary (such as cooling water coils on the exterior of the furnace shell) is acceptable, but only if it can be shown that failure of the water system boundary (for instance, through pinhole corrosion or overpressure damage) could not credibly introduce water into the primary confinement.

For instance, use of jacketed vessels where the confinement boundary acts as the inner jacket wall is not acceptable due to the potential of a crack, pit or other defect developing on the inner wall and creating a water leak that would not be detectable outside of the furnace. 


\begin{tabular}{l|lll|} 
URANIUM PROTOTYPE GLOVEBOX & Identifier: & SPC-2954 & \\
AND FURNACE DESIGN AND BUILD & Revision: & 0 & \\
& Effective Date: & $01 / 19 / 21$ & Page: B13 of B51 \\
\hline
\end{tabular}

2.2.2.5 REQUIREMENT - Any use of cooling water will be analyzed by INL to ensure any risk of criticality is identified and mitigated.

BASIS - Although use of cooling water in equipment used with fissile material is discouraged, such use can be (and has been in INL experience) accommodated with application of effective engineering controls. Under most circumstances, use of cooling water external to the glovebox should not create any criticality issues, however, the particular configuration must be evaluated by INL analysts.

\subsection{Operational Requirements}

\subsubsection{Service Life and Maintenance Intervals}

2.3.1.1 REQUIREMENT - The operating life of the casting system will be 40 years, with an estimated average operational cycle frequency of 40 casting cycles per year. The design life of the casting system shall be at least 20 years.

BASIS - This is the intended operation lifespan of the system, based on programmatic input. Major components of the casting system such as the furnace vessel and piping will be designed for a life of at least 20 years due to the difficulty and expense of replacing these components.

2.3.1.2 REQUIREMENT - Non-Routine Repair/Replacement interval shall be at least 5 years.

BASIS - For repairs and replacements that require significant disassembly of the furnace, a 5 year design life is the minimum for achieving acceptable production rates once the system transitions to a production mode.

2.3.1.3 REQUIREMENT - Routine Repair/Replacement interval shall be at least three months.

BASIS - For repairs and replacements that require only minor disassembly and that may be quickly performed, a three month minimum design life will provide acceptable operational cost and impact. 


\begin{tabular}{l|lll|} 
URANIUM PROTOTYPE GLOVEBOX & Identifier: & SPC-2954 & \\
AND FURNACE DESIGN AND BUILD & Revision: & 0 & \\
& Effective Date: & $01 / 19 / 21$ & Page: B14 of B51 \\
\hline
\end{tabular}

\subsubsection{Electrical Requirements}

2.3.2.1 REQUIREMENT - Furnace shall be designed for 480Y/277V 3-phase electrical supply, single point connection. Control system voltage shall be less than $50 \mathrm{~V}$ and shall be derived from $480 \mathrm{~V}$ supply, with the use of control power transformer(s) and/or power supply(s).

BASIS - INL electrical system requirement for this type of system.

2.3.2.2 REQUIREMENT - AC power distribution within a console enclosure, cabinet or panel shall be configured to provide physical separation from signal cabling.

BASIS - Avoid degradation of signals due to induced noise from power cabling.

2.3.2.3 REQUIREMENT - Electric equipment shall be de-rated for operation at 5000' elevation.

BASIS - Required for equipment to operate reliably at site elevation.

\subsubsection{Maintenance Requirements}

2.3.3.1 REQUIREMENT - The furnace will be designed to allow disassembly and maintenance to be performed inside the glovebox. All components that may be expected to require replacement, repair or refurbishment over the design lifespan shall be small enough to fit through a 15 inch bag port (15 inch ID). This will include components that can be expected to be damaged due to expected accidents such as crucible failure or that could be damaged during normal operations or maintenance activities.

BASIS - Based on INL experience in the FMF, the largest practical size for bag out ports in routine use is 15 inches inside diameter. Extracting or inserting larger components into a glovebox typically requires operations such as window removal that require extensive service outage of both the glovebox in question and of any gloveboxes in the vicinity. 


\begin{tabular}{l|lll|} 
URANIUM PROTOTYPE GLOVEBOX & Identifier: & SPC-2954 & \\
AND FURNACE DESIGN AND BUILD & Revision: & 0 & \\
& Effective Date: & $01 / 19 / 21$ & Page: B15 of B51 \\
\hline
\end{tabular}

2.3.3.2 DESIRED - Where not precluded by other considerations, 304 or 316 series austenitic stainless steels are preferred for pressure boundary components such as the vessel shell, flanges, piping and accumulator tanks.

BASIS - These materials are relatively low cost and provide excellent corrosion resistance for this type of furnace application as long as they are not exposed to fuel alloy at higher temperatures.

2.3.3.3 REQUIREMENT - Components that cannot be removed through the 15 inch transfer port (such as the furnace vessel, furnace vessel flange and accumulator vessel) shall be designed to remain operational through the design life (see 2.3.1) of the casting system without repair or replacement.

BASIS - Replacement or repair of components that require opening of the confinement boundary is an extremely expensive and time consuming-operation that would necessitate cessation of operation for the entire production facility for an extended period.

2.3.3.4 REQUIREMENT - Components that require significant disassembly of the furnace for repair or replacement shall be designed to achieve the design life specified for non-routine repair/replacement (see 2.3.1.2).

BASIS - Provide acceptable operation impact and costs. This includes such components as induction coils, valves and thermal shutters.

2.3.3.5 REQUIREMENT - Components that can be replaced quickly and without significant system disassembly shall be designed to achieve the minimum design life specified for routine repair/replacement (see 2.3.1.3) if practical. Components that cannot practically meet this design life shall be designated as "consumable".

BASIS - Provide acceptable operation impact and costs. This includes primarily external components such as pallet elevator flange seals and viewing windows. 


\begin{tabular}{l|lll|} 
URANIUM PROTOTYPE GLOVEBOX & Identifier: & SPC-2954 & \\
AND FURNACE DESIGN AND BUILD & Revision: & 0 & \\
& Effective Date: & $01 / 19 / 21$ & Page: B16 of B51 \\
\hline
\end{tabular}

2.3.3.6 REQUIREMENT - The furnace shall be designed to allow removal and installation of an entire furnace (including the furnace shell) without lifting or disturbing the glovebox. A sealable cover shall be efficiently stored inside the box to provide an alternate confinement boundary when one of the furnaces is removed. This cover shall provide additional glovebox floor working space when installed. Each furnace flange shall incorporate an external bagging ring for attachment of an external confinement when removing a contaminated furnace shell.

BASIS - The INL has determined that it may be necessary to operate with a single installed furnace under certain circumstances (for instance, if one furnace shell requires replacement). These provisions allow moving the primary confinement boundary to the floor plate, which will allow removal of the associated furnace vessel and eventual reinstallation.

2.3.3.7 REQUIREMENT - Water cooling features such as cooling plates and coils should be designed to allow replacement without disturbing the primary confinement boundary. If this is not possible, these components shall be designed to remain operational for the design life of the system.

BASIS - As noted in Section 2.3.2.3, disturbing the primary confinement boundary for maintenance involves some extreme production impacts.

2.3.3.8 REQUIREMENT - Use of radiation-sensitive components and materials (such as Teflon) should be avoided, particularly in the vicinity of the furnace.

BASIS - While overall radiation dose rates should not be high enough to cause rapid degradation, localized alpha contamination could generate enough dose to create localized effects in sensitive materials. 


\begin{tabular}{l|lll|} 
URANIUM PROTOTYPE GLOVEBOX & Identifier: & SPC-2954 & \\
AND FURNACE DESIGN AND BUILD & Revision: & 0 & \\
& Effective Date: & $01 / 19 / 21$ & Page: B17 of B51 \\
\hline
\end{tabular}

\subsubsection{General Safety Requirements}

2.3.4.1 REQUIREMENT - Accessible thermally hot surfaces $\left(>140^{\circ} \mathrm{F}, 60^{\circ} \mathrm{C}\right)$ should be either guarded or insulated to ensure that personnel cannot contact hot surfaces during the casting operation. If surfaces inside the glovebox are expected to exceed this temperature, administrative controls will be specified to avoid contact of gloves with these surfaces.

BASIS - Contact with surfaces with temperatures in excess of $140^{\circ} \mathrm{F}$ can result in thermal injuries (burns). If temperatures are sufficiently high, perforation of gloves can occur if the gloves come in contact with these surfaces.

2.3.4.2 REQUIREMENT - Electrical conductors and connectors shall be insulated or guarded to prevent contact with energized connections per $\mathrm{NEC}^{\mathrm{h}}$ requirements to protect personnel from shock and to ensure that circuits cannot be shorted by dropped tools or equipment.

BASIS - Accessible un-insulated electrical conductors present the potential for electrical shock injuries. Inside the glovebox, they also may present the potential for electric flash or damage to equipment.

2.3.4.3 REQUIREMENT - Grounding shall be in accordance with NEC requirements and IEEE-1100 ${ }^{\mathrm{i}}$.

BASIS - Required for INL electrical systems to guard against personnel shock hazards.

2.3.4.4 REQUIREMENT - All electrical equipment including industrial control panels shall have a short circuit current rating of 10KA and comply with the requirements of NFPA70 and specifically Article 409 for Industrial Control Panels.

BASIS - INL requirement for control panels to protect personnel.

h. NFPA-70, National Electrical Code

i. IEEE 1100, IEEE Recommended Practices for Powering and Grounding Electronic Equipment, Institute of Electrical and Electronics Engineers. 
URANIUM PROTOTYPE GLOVEBOX AND FURNACE DESIGN AND BUILD

$\begin{array}{ll}\text { Identifier: } & \text { SPC-2954 } \\ \text { Revision: } & 0 \\ \text { Effective Date: } & 01 / 19 / 21\end{array}$

Page: B18 of B51

2.3.4.5

REQUIREMENT - The control cabinet(s) supporting the furnace shall comply with UL-508A ${ }^{\mathrm{j}}$.

BASIS - INL requirement for control panels to protect personnel.

2.3.4.6 REQUIREMENT - Control cabinets shall be designed and constructed to be finger safe as defined by 20 IEC- $60529^{\mathrm{k}}$.

BASIS - INL requirement for control panels to protect personnel working inside cabinets

2.3.4.7 REQUIREMENT - To the extent possible, pinch points and sharp edges shall be avoided in equipment that requires handling during operation or maintenance.

BASIS - Outside the glovebox, sharp edges and pinch points present a hazard to personnel. Inside the glovebox, there is the added potential for puncturing of gloves and potential personnel contamination.

\subsubsection{Control System Operation}

2.3.5.1 REQUIREMENT - The casting process will be controlled by an automatic programmable system. This system will allow the operator to input basic casting parameters such as furnace temperature, temperature ramp rate, hold times, furnace pressure during melting and injection casting pressure. It will be possible for the operator to either set these parameters individually or as part of a pre-defined "recipe". If possible, once a casting run commences, operator action should not be required until the casting process is completed.

BASIS - To create a high quality casting product, the various casting parameters must be tightly controlled and repeatable. The required control and repeatability is not practical without automation of the control system.

Parameters will be determined during a lengthy process development stage prior to transitioning into a production mode. Thus, the important control parameters must be

j. UL-508A, Standard for Industrial Control Panels, Underwriters Laboratories.

k. IEC 60529, Degrees of Protection Provided by Enclosures, International Electricotechnical Commission. 
adjustable. Once parameters are developed, they must be repeatable. In addition, it is very likely that alternate casting alloy mixes and varying casting geometries will be required during the life of the system. This will require that different "recipes", tailored to these different conditions, may be used.

2.3.5.2 REQUIREMENT - It shall be possible for the operator to alter or override the automatic programming during the casting run. This override shall not allow violation of system trips or interlocks necessary to protect the equipment from damage. This shall include variations of temperatures, pressures and any other programmed parameters.

BASIS - There are a number of situations, particularly during process development, in which it may be necessary to take manual control of certain casting system operations or parameters (for instance, temporarily opening the thermal shutters to view the melt). While these operations are occasionally necessary, the system should not allow operations that may damage the system (for instance, lowering of the pallet with the shutters closed).

2.3.5.3 REQUIREMENT - A physical emergency stop button shall be provided to allow the operator to quickly place the system in a safe state in case of an un-expected event. The safe state is defined in Section 2.3.7.6. The emergency stop circuit will be designed to allow connection of additional remote stop buttons as determined necessary by the laboratory.

BASIS - The ability to quickly secure the casting system in case of events such as facility accidents and similar situations is necessary to allow the operator to quickly place the system in a safe state and to then evacuate the facility if necessary. It is anticipated that addition of additional remote emergency stop buttons outside the operation area will be needed to allow the system to be placed in a safe state from a remote area in case an event requires immediate evacuation of the facility. 
REQUIREMENT - A digital acquisition system (DAS) shall be provided. System pressures, temperatures, control setpoints and control functions (such as shutter and pallet positions) shall be recorded at a programmable interval that can be set through a range of 250 milliseconds to 5 seconds. The system shall include the capability to locally monitor these parameters and display both current readings and trends. System storage shall be available to record data at 250 millisecond intervals for a period of at least 3 hours. Ethernet output shall be provided to allow the system to be connected to the facility DAS system if desired.

BASIS - The ability to record system parameters is necessary for quality control, verification, system troubleshooting and a number of other important operations.

2.3.5.5 REQUIREMENT - The DAS interface shall include a "time stamp" function. This function will allow the operator, by pressing a single button on the operator interface, to insert a digital marker into the data file. This time stamp should allow the operator to insert a short remark regarding the time stamp.

BASIS - In case of unusual or anomalous events during operation, it is very helpful to have this ability to allow the event to be quickly identified when later reviewing data for investigation of the event.

2.3.5.6 REQUIREMENT - A non-contact device (Infrared Pyrometer or similar) shall be provided to allow measurement of the melt temperature. This device may also be used for furnace control if practical.

BASIS - It is desired to have the capability to accurately measure temperature of the melt during the melting and casting process. It is recognized that it may not be practical to maintain a pyrometer in view of the melt, and therefore use of a pyrometer for furnace control may not be practical. 
URANIUM PROTOTYPE GLOVEBOX AND FURNACE DESIGN AND BUILD

$\begin{array}{ll}\text { Identifier: } & \text { SPC-2954 } \\ \text { Revision: } & 0 \\ \text { Effective Date: } & 01 / 19 / 21\end{array}$

Page: B21 of B51

2.3.5.7

REQUIREMENT - The furnace control system will include control features necessary to avoid over-temperature damage due to either failure of the primary control system or operator error. These features will be independent of the primary furnace control system such that a single component failure would not disable furnace control AND over-temperature protection. The over-temperature control will include temperature monitoring and associated trips for critical locations (such as flanges and furnace vessel midbody shell).

BASIS - An independent over-temperature protection control will ensure that the furnace is not damaged due to simple operator error or single component failure.

2.3.5.8 REQUIREMENT - The furnace will provide the capability to periodically make visual observations of the melt and record video of the melt process. This may be provided by use of a pyrometer with video capability, or a dedicated viewing window and video camera.

BASIS - This capability has been shown to be valuable for other similar casting furnaces, particularly during casting process development. Since opening the thermal shutters may be required to view the melt, only periodic viewing is anticipated to avoid exposing the upper portions of the furnace to excessive thermal radiation.

2.3.5.9 REQUIREMENT - The furnace control system shall be designed to provide control of the melt/cast process using installed temperature detection and by monitoring energy input to the furnace. Other control schemes to provide control of alloy melting and temperature may be proposed by the designer.

BASIS - It is anticipated that process development would require the ability to monitor furnace temperature to establish power input profiles for un-tested alloys and batch sizes. Once power input/time profiles for a particular alloy and batch size are developed, these melt characteristics could be used directly for melt/casting control. 


\begin{tabular}{l|lll|} 
URANIUM PROTOTYPE GLOVEBOX & Identifier: & SPC-2954 & \\
AND FURNACE DESIGN AND BUILD & Revision: & 0 & \\
& Effective Date: & $01 / 19 / 21$ & Page: B22 of B51 \\
\hline
\end{tabular}

\subsubsection{System Capabilities}

2.3.6.1 REQUIREMENT - The furnace will accommodate a mold pallet with mold length of up to 22 inches and mold array diameter of 5.75 inches. The designer shall develop a prototype pallet design that accommodates 135 molds for acceptance testing and evaluation as illustrated below. Three (3) pallets and four hundred, twenty (420) molds will be provided with the furnace for INL use. General features of this pallet are in the next two figures.

Provision of prototype molds with standard commercial tolerances is acceptable, as these will not be used to create production castings.

Holes in the pallet central tube should be distributed as necessary to cool the molds from the top down after molds are filled during the casting process.
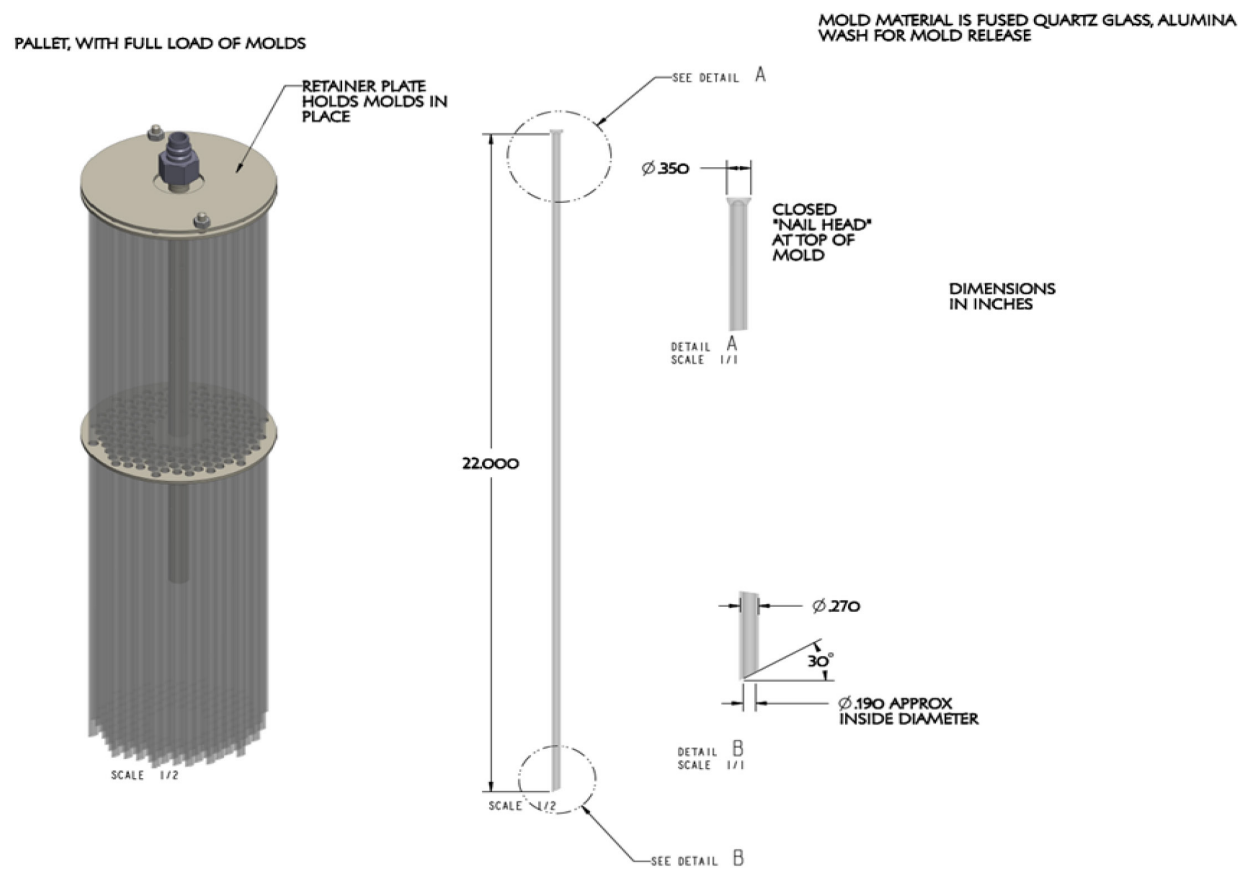

Figure 2. Pallet and Molds. 


\begin{tabular}{l|lll|} 
URANIUM PROTOTYPE GLOVEBOX & Identifier: & SPC-2954 & \\
AND FURNACE DESIGN AND BUILD & Revision: & 0 & \\
& Effective Date: & $01 / 19 / 21$ & Page: B23 of B51 \\
\hline
\end{tabular}

EACH PLATE HAS AN ARRAY OF HOLE FOR HOLDING MOLDS. ARRAYS ARE ALIGNED BETWEEN PLATES. HOLES O.275 INCH NOMINAL DIAMETER WITH 375 CENTER SPACING.
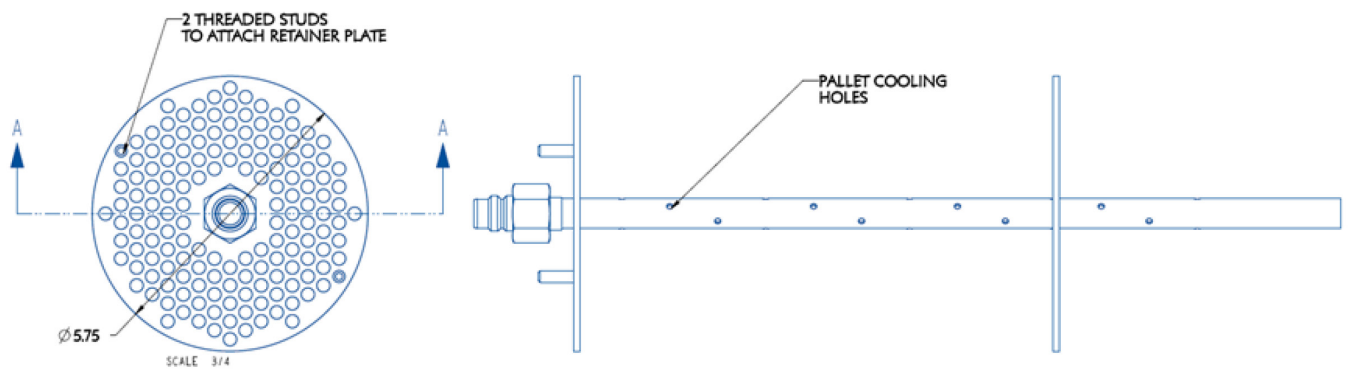

SPACING OF PLATES AS NEEDED TO SUPPORT MOLDS, LENGTH OF CENTER POST SUFFICIENTIY LONG TO
PROVDE PALLET COOLING, BUT NOT SO LONG AS TO PRESENT RISK OF CONTACTNNG MELT.

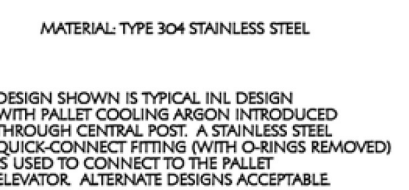

CONINECTING FITING TO

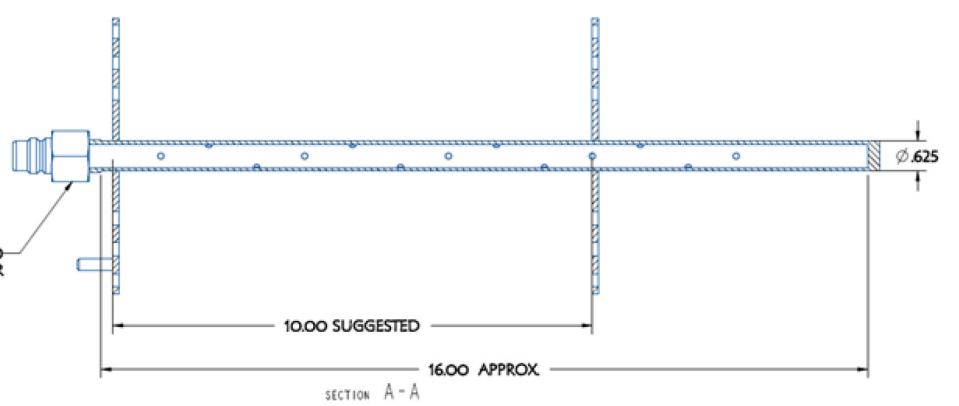

DIMENSIONS IN INCHES

Figure 3. Casting Pallet Frame.

BASIS - This requirement is based on prototyping the necessary production rates and user requirements for dimensions of the cast slugs in the VTR process. INL experience has demonstrated that a few inches on either end of a cast slug is typically unusable due to unavoidable casting defects. Three fully loaded pallet assemblies will support acceptance testing of the furnace both at the vendor facility prior to shipment and at INL after delivery.

Use of a full mold complement will ensure that the casting system operates properly with a full casting load. Mold tubes may be of standard commercial tolerances for quartz glass tubing, as high accuracy on the final slug diameters is not required to verify furnace operation. 
URANIUM PROTOTYPE GLOVEBOX AND FURNACE DESIGN AND BUILD

$\begin{array}{ll}\text { Identifier: } & \text { SPC-2954 } \\ \text { Revision: } & 0 \\ \text { Effective Date: } & 01 / 19 / 21\end{array}$

Page: B24 of B51

2.3.6.2 REQUIREMENT - The furnace will be designed to accept a graphite crucible/susceptor of up to 7 inches in diameter and 11 inches in height. A prototype crucible will be developed for acceptance testing and evaluation. Three (3) crucibles shall be provided with the furnace for INL use. Some general conceptual features and geometry are presented below. It is noted that addition of features needed for the furnace operation (such as alignment pockets for thermocouples, features to assist heal breaking) is expected. Material grades shown are typical for current INL crucibles, other grades may be accepted if determined beneficial by the designer.
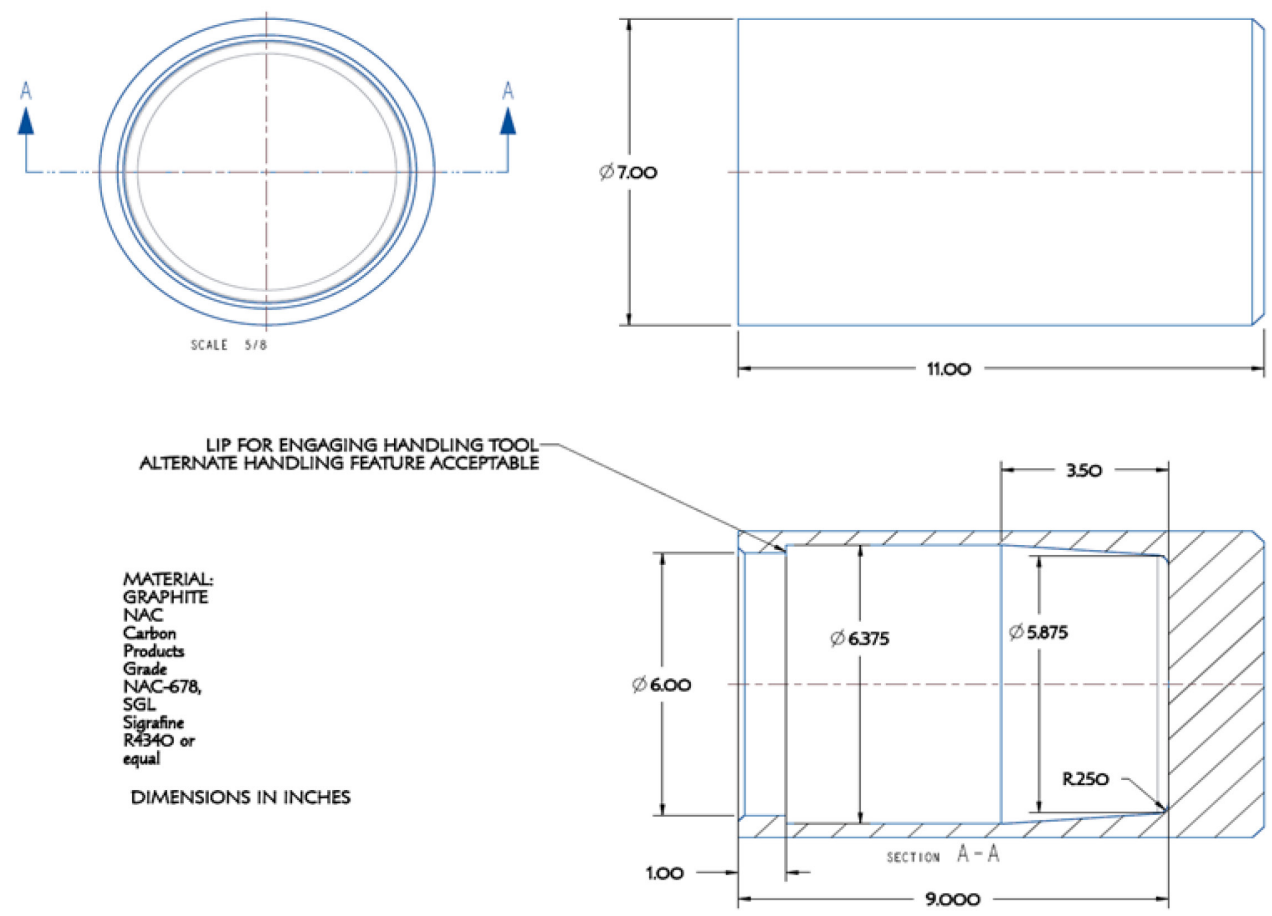

Figure 4. Crucible.

BASIS - These dimensions are based on crucibles previously used at INL, adjusted to accommodate the casting mass and material specified in Section 2.3.5.4. It is noted that these are representations of conceptual designs and additional features may be needed for alignment, thermocouple access, etc. 


\begin{tabular}{l|lll|} 
URANIUM PROTOTYPE GLOVEBOX & Identifier: & SPC-2954 & \\
AND FURNACE DESIGN AND BUILD & Revision: & 0 & \\
& Effective Date: & $01 / 19 / 21$ & Page: B25 of B51 \\
\hline
\end{tabular}

2.3.6.3 REQUIREMENT -The crucible size shall provide an internal volume of at least twice the anticipated melt volume (or larger).

BASIS - Excess internal volume is necessary due to the anticipated use of small, irregular ingots as initial feedstock, and to guard against "splashing" of the melt outside the crucible due to turbulence created by the induction heating and/or mixing process.

2.3.6.4 REQUIREMENT - Although this furnace will be used to cast $10 \%$ zirconium-uranium alloy the furnace design will be designed to heat a maximum mass of $30 \mathrm{~kg}$ of $20 \%$ Plutonium (Pu)-10\%Zirconium (Zr)-Uranium (U) alloy. Estimated volume of this mass at liquidus is approximately 2200 cubic centimeters (133.6 cubic inches).

BASIS - This casting mass will allow for a sufficient number of cast slugs to meet anticipated production requirements. Excess internal volume is necessary due to the anticipated use of small, irregular ingots as initial feedstock.

\subsubsection{System Performance}

2.3.7.1 REQUIREMENT - The furnace shall be capable of heating the casting material to a temperature of $1550^{\circ} \mathrm{C}$. Casting temperature may range between $1000-1550^{\circ} \mathrm{C}$.

BASIS - Casting temperature is based on the INL experience with casting these types of materials.

2.3.7.2 REQUIREMENT - The furnace will be designed for an allowable pressure range of full vacuum to $100 \mathrm{psig}$ at the maximum anticipated shell temperature.

BASIS - 100 psig is above the gas supply pressures used for the casting system. This should leave temperature increase as the only potential cause of vessel overpressure. Due to the inherent slow nature of this increase, the pressure relief capacity will be minimized. 
URANIUM PROTOTYPE GLOVEBOX AND FURNACE DESIGN AND BUILD

$\begin{array}{ll}\text { Identifier: } & \text { SPC-2954 } \\ \text { Revision: } & 0 \\ \text { Effective Date: } & 01 / 19 / 21\end{array}$

Page: B26 of B51

2.3.7.3 REQUIREMENT - The accumulator tank design will be based on providing sufficient volume and pressure to achieve a final casting pressure of 30 psig in the vacuum furnace. Allowable working pressure of the accumulator will be 150 psig.

BASIS - The principal requirement is that the system be capable of achieving up to 30 psig in the casting furnace during injection. The casting pressure is dependent upon the initial accumulator pressure, the accumulator size, furnace volume and overall system volumes. Since the accumulator tank shell is part of the Primary Confinement Boundary, it is desired that a significant margin between operating pressure and allowable working pressure be provided.

2.3.7.4 REQUIREMENT - During the melting process, the furnace pressure will be controlled at pressure as set in the control system. The pressure system will allow control of furnace pressure throughout a band of $30 \mathrm{psig}$ (42 psia) to 100 Torr absolute and will control to an accuracy of $+/-5 \%$ of set pressure. The pressure system will allow dynamic adjustment of the pressure setpoint throughout the melting and casting operation. Use of separate control systems for vacuum range and positive pressure ranges is acceptable. The control system will also allow use of "full vacuum" melting. In this mode, pressure will not be controlled in a specific band, but will be maintained at the maximum vacuum achievable by the vacuum system.

BASIS - The system is operated at a reduced pressure with respect to the glovebox, both to reduce convective heat transfer to the furnace shell, and to reduce the potential for leakage of contamination from the furnace into the glovebox. Some highly radioactive contaminants that naturally occur in the casting alloy have significant vapor pressure at the casting temperature. Melting is typically performed at absolute pressures of 400-500 Torr or higher to suppress evaporation of these contaminants. Based on some INL reports, positive pressures in the 15-30 psig range have been used to suppress arcing in the induction coils (referred to in the reports as "corona effect") at higher frequencies and voltages. INL also desires the capability to heat under full vacuum conditions, where the furnace is continuously evacuated while heating instead of requiring control within a specific band. 
2.3.7.5 REQUIREMENT - After injection, the pressure control system will be capable of maintaining the furnace pressure at a positive pressure between 5 and 30 psig with or without pallet cooling argon flow.

BASIS - After the molds are filled, the furnace is normally kept at a positive pressure while the cast slugs are solidifying. Precise pressure control is not required during this period.

2.3.7.6 REQUIREMENT - During the casting process, the system shall be capable of raising pressure in the furnace from 50 milliTorr absolute to $30 \mathrm{psig}$ (42.1 psia) within one second.

BASIS - A vacuum is necessary to ensure that the molds can be filled during injection. A rapid pressure increase is required to ensure that the molds are filled before the casting alloy can solidify.

2.3.7.7 REQUIREMENT - Maximum time for driving the pallet elevator between full up and full down positions shall be no more than 15 seconds.

BASIS - It is necessary to be able to quickly insert the molds into the melt to avoid excess heating of the molds after the shutters open and to minimize evaporation of volatile contaminants in the melt during the injection process.

2.3.7.8 DESIRED - The vacuum system should be capable of lowering pressure in the furnace from 700 Torr to $<1$ Torr within ten minutes or less. Shorter time is preferred.

BASIS - This time both minimizes time for evaporation of volatile contaminants once the furnace pressure is lowered and helps control the overall cycle time.

2.3.7.9 REQUIREMENT - Time for charging the accumulator from 0 psig to the design operating pressure will be no more than 10 minutes.

BASIS - This time will allow reasonable cycle times for the system 


\begin{tabular}{l|lll|} 
URANIUM PROTOTYPE GLOVEBOX & Identifier: & SPC-2954 & \\
AND FURNACE DESIGN AND BUILD & Revision: & 0 & \\
& Effective Date: & $01 / 19 / 21$ & Page: B28 of B51 \\
\hline
\end{tabular}

2.3.7.10 REQUIREMENT - Accumulator pressure will be controlled at the desired setpoint $+/-2 \%$. The setpoint will allow adjustment by the control system. It is desired that the control system be capable of establishing an accumulator pressure based on the desired casting pressure.

BASIS - Accumulator pressure needs to be controlled sufficiently to provide control of the final casting pressure. This control accuracy is deemed sufficient. It would be helpful to the operator if the control system were able to calculate the required accumulator pressure for a particular casting pressure, but it is recognized that this may not be practical.

2.3.7.11 REQUIRED - The target average heat-up rate for the loaded furnace is $50^{\circ} \mathrm{C} / \mathrm{min}$ up to the alloy casting temperature with optional hold points for a step process. The furnace shall be capable of maintaining temperature for an additional one hour to provide mixing of the alloy.

BASIS - It is desired that the melting cycle be kept reasonably short to minimize cycle times, while maintaining sufficient time in the molten state for the casting alloy to be fully mixed.

\subsubsection{System Limits, Failures and Protective Features}

2.3.8.1 REQUIREMENT - The designer shall ensure that thermal contraction and expansion effects will not cause damage or degradation to the furnace, glovebox, or confinement boundary seals.

BASIS - Differences in thermal expansion between different components can result in high stresses and potentially failure of component. Analyses of these effects and inclusion of appropriate features (such as expansion joints or flexible mounting) is anticipated to be necessary for the systems to provide long term service. 


\begin{tabular}{l|lll|} 
URANIUM PROTOTYPE GLOVEBOX & Identifier: & SPC-2954 & \\
AND FURNACE DESIGN AND BUILD & Revision: & 0 & \\
& Effective Date: & $01 / 19 / 21$ & Page: B29 of B51 \\
\hline
\end{tabular}

2.3.8.2 REQUIREMENT - The designer shall ensure that seal materials are not exposed to temperatures that will cause degradation.

BASIS - Seal material such as elastomer O-rings that have limited temperature capability must be protected from thermal damage or degradation to ensure acceptable performance of the furnace system.

2.3.8.3 REQUIREMENT - Over-temperature limits shall be established by the designer to ensure that the furnace is protected from equipment damage due to failure or fault in the temperature control system. This "hard limit" shall be set at the design temperature of the system that cannot be adjusted. An operation limit shall be available and adjustable up to the design limit.

BASIS - Design analysis may be needed to establish emergency temperature / process limits.

2.3.8.4 REQUIREMENT - If required, the control system will include overpressure trips for the furnace and the accumulator tank. These trips will be set no higher than $90 \%$ of the allowable working pressure of the components.

BASIS - The control system should provide automatic trips and limits to prevent overpressure of the furnace and piping system.

2.3.8.5 REQUIREMENT - Pressure relief devices for the furnace and the accumulator tank, if required, shall be vented to the facility suspect exhaust system. Effluent from these devices is not required to be filtered prior to entering the facility suspect exhaust system.

BASIS - Gas released from the furnace and accumulator tank will contain significant radiological contamination and must not be released to the environment directly. Pressure relief devices are not filtered prior to discharge into the suspect exhaust system because filter plugging could negatively impact the operation of these emergency devices. 


\begin{tabular}{l|lll|} 
URANIUM PROTOTYPE GLOVEBOX & Identifier: & SPC-2954 & \\
AND FURNACE DESIGN AND BUILD & Revision: & 0 & \\
& Effective Date: & $01 / 19 / 21$ & Page: B30 of B51 \\
\hline
\end{tabular}

2.3.8.6 REQUIREMENT - “SAFE STATE”- In case of an unexpected situation that, if not mitigated, could present risk of damage to the system or to the safety of personnel, the system shall automatically be placed into a "safe state". Upon system restoration or fault correction, the system will remain in this state until recovery action is initiated. Control system parameters shall reset to rest values:

- The pallet shall be in the raised position

- $\quad$ The thermal shutters shall be closed

- $\quad$ Furnace power shall be de-energized

- $\quad$ Pressurized gas and vacuum shall be secured.

- $\quad$ The accumulator tank shall be vented to suspect exhaust.

- $\quad$ The furnace shall be vented to suspect exhaust.

- Cooling water shall continue to flow.

Situations that will cause the system to enter the "safe state" include:

- Loss of normal electrical power

- $\quad$ Control system failure, including loss of control or over-temperature sensor inputs (primary and backup)

- $\quad$ Actuation of the system E-Stop

- Over-temperature of "hard limit" system actuation.

- $\quad$ Overpressure trip actuation.

- $\quad$ Loss of cooling water flow (sustained).

- $\quad$ Additional situations as determined necessary by the Laboratory during design and development.

BASIS - The cold, depressurized state is generally the safest state for the system after failure. A failure into this condition will ensure that damage doesn't occur to the equipment and will normally not negatively impact the 


$\begin{array}{lll}\text { Identifier: } & \text { SPC-2954 } \\ \text { Revision: } & 0 \\ \text { Effective Date: } & 01 / 19 / 21\end{array}$

casting alloy heel. When the system is restored, it is important that all recovery be performed in a controlled manner, and that re-energizing of the system does not result in the system automatically attempting to re-establish stored control setpoints that remain from the time of the failure. If the failure occurs at a time where the pallet is lowered into the crucible, retraction of the pallet and closure of the shutters will greatly simplify system recovery.

2.3.8.7 REQUIREMENT - Systems that are required to operate to protect the furnace during loss of normal electrical power shall be powered from standby power (UPS). These include:

- $\quad$ Fluid system components that must operate to vent the systems

- $\quad$ Control systems as necessary to establish a safe state.

- $\quad$ Pallet elevator drives

- $\quad$ Furnace cooling water (not including the facility chiller loop).

BASIS - Required to protect the furnace during a loss of normal power.

\subsection{Owner Specified Technical Requirements}

\subsubsection{Code Requirements}

2.4.1.1 REQUIREMENT - Pressure systems associated with the furnace system shall be designed and fabricated in accordance with ASME B31.3. Piping inside the confinement boundary shall be considered at least normal category.

BASIS - Many of the general supply systems for clean fluids in the facility are considered building service piping and are covered by ASME B31.9. Additional rigor should be implied for piping associated with the casting process systems. It is noted that ASME B31.9 systems may supply gas and fluid to the ASME B31.3 systems. 
URANIUM PROTOTYPE GLOVEBOX AND FURNACE DESIGN AND BUILD

$\begin{array}{ll}\text { Identifier: } & \text { SPC-2954 } \\ \text { Revision: } & 0 \\ \text { Effective Date: } & 01 / 19 / 21\end{array}$

Page: B32 of B51

2.4.1.2 REQUIREMENT - The furnace vessel and accumulator tank shall be designed and fabricated as ASME Boiler and Pressure Vessel Code, Section VIII Division 1 pressure vessels.

BASIS - Pressure vessels on the INL are required to be designed and fabricated per ASME codes. INL does not consider these vessels to be required to meet ASME Section III.

2.4.1.3 REQUIREMENT - The furnace systems shall comply with NFPA-86.

BASIS - Furnaces at INL are required to meet NFPA-86 requirements.

\section{SUPPLEMENTAL DESIGN REQUIREMENTS}

\subsection{Required Analyses}

3.1.1 Pressure Systems Analysis - The designer shall provide all analyses required by the applicable ASME pressure codes for pressure piping and pressure vessels.

3.1.2 Overpressure Protection Analysis - The designer shall provide analyses required to validate overpressure protection requirements for the furnace vessel and accumulator tank per the ASME Boiler and Pressure Vessel Code, Section VIII, Division 1, UG-125 thru UG-140

3.1.3 Operational Limit Analysis - The designer shall provide analyses demonstrating the basis for system temperature or pressure limits needed to ensure safe operation of the casting system (see paragraphs 2.3.7.3 and 2.3.7.4).

3.1.4 Thermal Design Analyses - Analyses covering thermal performance of the furnace shall be provided. With specific concurrence of INL, results of direct measurements during system operational testing may be substituted for formal analysis. Topics to be covered include:

- $\quad$ Estimation of maximum surface temperatures of components. This shall identify any surfaces that required insulation or guarding (see paragraph 2.3.3). 
Identifier: $\quad$ SPC-2954

Revision: $\quad 0$

Effective Date: $01 / 19 / 21$

Page: B33 of B51

- $\quad$ Analysis of thermal expansion and contraction of components during furnace operation, including analysis of expected stresses in materials and validation of adequacy of the design (see paragraph 2.3.7.1.

- $\quad$ Analysis estimating maximum temperature ranges to that seals and materials will be subjected and demonstrating adequacy of seal materials (see paragraph 2.3.7.2 ).

- Analysis demonstrating safe operating temperature of induction coils and furnace materials.

- Identification of cooling system requirements such as coolant flow rates and estimation of heat rejection capacity required.

- $\quad$ Analyses validating temperatures used in ASME Code calculations.

- $\quad$ Analysis of system temperatures during loss of cooling (assuming design system response) to identify any requirements for backup cooling.

3.1.5 Induction Design Analyses - Analyses shall be provided that validate design of the induction heating furnace systems, including both heating performance and induction stirring performance.

3.1.6 Seismic Design Analyses - Seismic analyses of the furnace shell and accumulator tank shall be included in the overall seismic analysis of the glovebox system. To support seismic analysis of the system, the furnace designer shall provide models or data to the glovebox vendor that are compatible with modeling used by the glovebox manufacturer for seismic analysis.

\subsection{Operational Testing}

3.2.1 Operational test procedures shall be reviewed and approved by INL prior to performance. Operational testing shall be witnessed by INL representatives. Operational testing shall include, as a minimum, the following tests.

3.2.2 Initial Calibration and Individual Component Tests - All instrumentation shall be calibrated and instrument output to both control systems and digital acquisition systems shall be verified correct. Ability to operate individual components and subsystems shall be verified. 
3.2.3 Low Temperature System Testing -Proper system operations will be tested to ensure the system operates as designed under all conditions. This testing includes (but is not limited to).

\subsubsection{Low Temperature Recipe Testing - The system will be} tested empty (no alloy) with no pallet or molds installed. A casting recipe will be loaded and the casting operation will be run at reduced temperature $\left(200^{\circ} \mathrm{C}\right.$ recommended $)$ and casting pressure (10 psig). The system will be verified to operate properly per that recipe and DAS recordings will be reviewed to ensure proper operation and recording of data.

3.2.3.2 Low Temperature Recipe Override Testing - The system will be tested empty (no alloy) with no pallet or molds installed. A casting recipe will be loaded and the casting operation will be run at reduced temperature $\left(200^{\circ} \mathrm{C}\right.$ recommended) and casting pressure (10 psig). Once started, the operator will manually input new settings and verify the system operates in accordance with the overridden settings.

\subsubsection{Interlock Testing - The system will be tested empty (no} alloy) with no pallet or molds installed. The system will be tested to ensure all interlocks and safety trips operate properly. Initiating signals may be simulated as necessary.

3.2.4 High Temperature System Testing -Proper system operations will be tested to ensure the system operates as designed at elevated temperature. This testing includes (but is not limited to).

3.2.4.1 Initial High Temperature Testing - The system will be tested empty (no alloy) with no pallet or molds installed. The system will be operated at increasing target temperatures $\left(500^{\circ} \mathrm{C}, 1000^{\circ} \mathrm{C}\right.$ and $1550^{\circ} \mathrm{C}$ recommended) at a system pressure of 500 Torr absolute or higher as well as under a constant active vacuum. The system will be held at each temperature for 1 hour to ensure that temperature limits on components such as seals are not exceeded. This testing may be performed as a single test, or as a series of individual tests.

3.2.4.2 Melt/Stir Testing - The system will be tested with no pallet or molds installed. Elemental components of a suitable casting alloy, approved by INL, will be placed in the crucible. The casting alloy will be melted and stirred for at least 30 minutes. Once cooled, the alloy will be provided to INL (or an independent testing laboratory approved by INL) 
URANIUM PROTOTYPE GLOVEBOX AND FURNACE DESIGN AND BUILD

$\begin{array}{ll}\text { Identifier: } & \text { SPC-2954 } \\ \text { Revision: } & 0 \\ \text { Effective Date: } & 01 / 19 / 21\end{array}$

to ensure acceptable homogeneity of the alloy $(<10 \%$ elemental variation through the sample).

3.2.5 Surrogate casting demonstration -Furnace operation shall be validated by performance of induction casting using a surrogate material. 15-16 kilograms of copper-nickel (50/50) alloy shall be used as a surrogate unless another suitable alloy is identified and approved by INL.

\section{CONCEPTUAL DESIGN}

NOTE: $\quad$ This section describes the development of the conceptual design for a fuel casting furnace to be used in the development and demonstration of fuel fabrication for the new Versatile Test Reactor (VTR). This system will be installed in a custom glovebox located in the Fuel Manufacturing Facility (FMF). It should be noted that these concepts are not well developed, particularly with respect to furnace element design, electromagnetic characteristics and heat transfer. The design herein should be considered as conceptual guidance for developing the final casting furnace for the VTR design, but is not considered binding to the prototype furnace described in this specification.

\subsection{Background}

The proposed VTR will utilize uranium-plutonium-zirconium (U-Pu-Zr) metallic fuel similar to that used in EBR-II and FFTF. The VTR Fuel Casting System will be used to develop and demonstrate the fuel fabrication for this new reactor. Fuel development and demonstration will include all equipment necessary to create VTR fuel elements from receipt of the elemental metals and alloys through final inspection and acceptance of a reactor-ready fuel element.

The furnace and pressure systems described herein will be used in development of the fuel casting process.

Metallic fuels have been produced at MFC (formerly Argonne National Laboratory - W) since the early 1960s. These fuels have been principally manufactured using injection casting systems. The basic injection casting process is still being used at MFC for casting experimental materials, and the systems used are very similar to those early casting systems. Generally, injection casting involves melting the fuel alloys in a furnace (most commonly an induction furnace) under vacuum, immersing the end of an array of glass (Vycor ${ }^{\mathrm{TM}}$ or quartz) molds into the alloy, and quickly pressurizing the furnace to force the alloy into the molds. Once the molds cool, the glass molds are broken and the alloy slugs retrieved.

The intended VTR fuel composition is 70\% uranium, 20\% plutonium and $10 \%$ zirconium (referred to as U-20Pu-10Zr). INL has produced injection cast fuels of this composition, but at much smaller batch and slug sizes than will be needed for 
the VTR fuel elements. The current fuel design will require casting pins of roughly 0.190 inch diameter and 18 inches length, in batches of 135 pins. Based on INL experience with anomalies at the ends of the elements (such as hot tears), molds will be up to 22 inches in length.

\subsection{General Furnace Conceptual Design}

The conceptual design is intended to demonstrate a feasible furnace system configuration that can meet the process requirements within the inherent space limitations imposed by the need to perform loading, unloading, and maintenance within a glovebox in the FMF.

The furnace will be used to injection cast fuel alloy into molds as shown in the following figure.

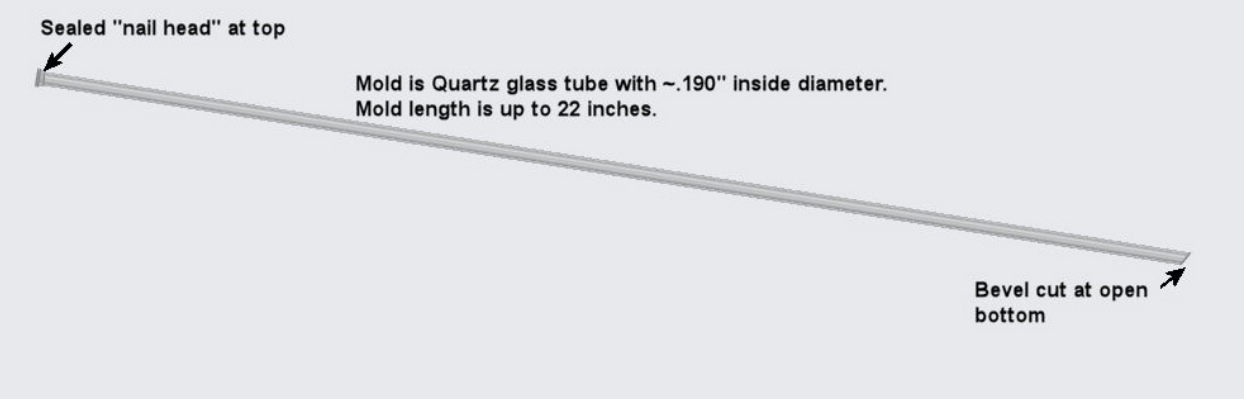

Figure 5. Injection Casting Mold.

These molds are very similar to molds previously used in the INL casting furnaces, but are longer to produce the longer fuel slugs that will be required for the VTR fuel design. The molds will be internally washed with a zirconia solution to facilitate separation of the mold from the cast slug.

To achieve the required throughput, the molds are placed in a frame and each casting operation will mold up to 135 fuel slugs. The array of molds for each casting operation is referred to as a "pallet". 


\begin{tabular}{l|lll|} 
URANIUM PROTOTYPE GLOVEBOX & Identifier: & SPC-2954 & \\
AND FURNACE DESIGN AND BUILD & Revision: & 0 & \\
& Effective Date: & $01 / 19 / 21$ & Page: B37 of B51 \\
\hline
\end{tabular}

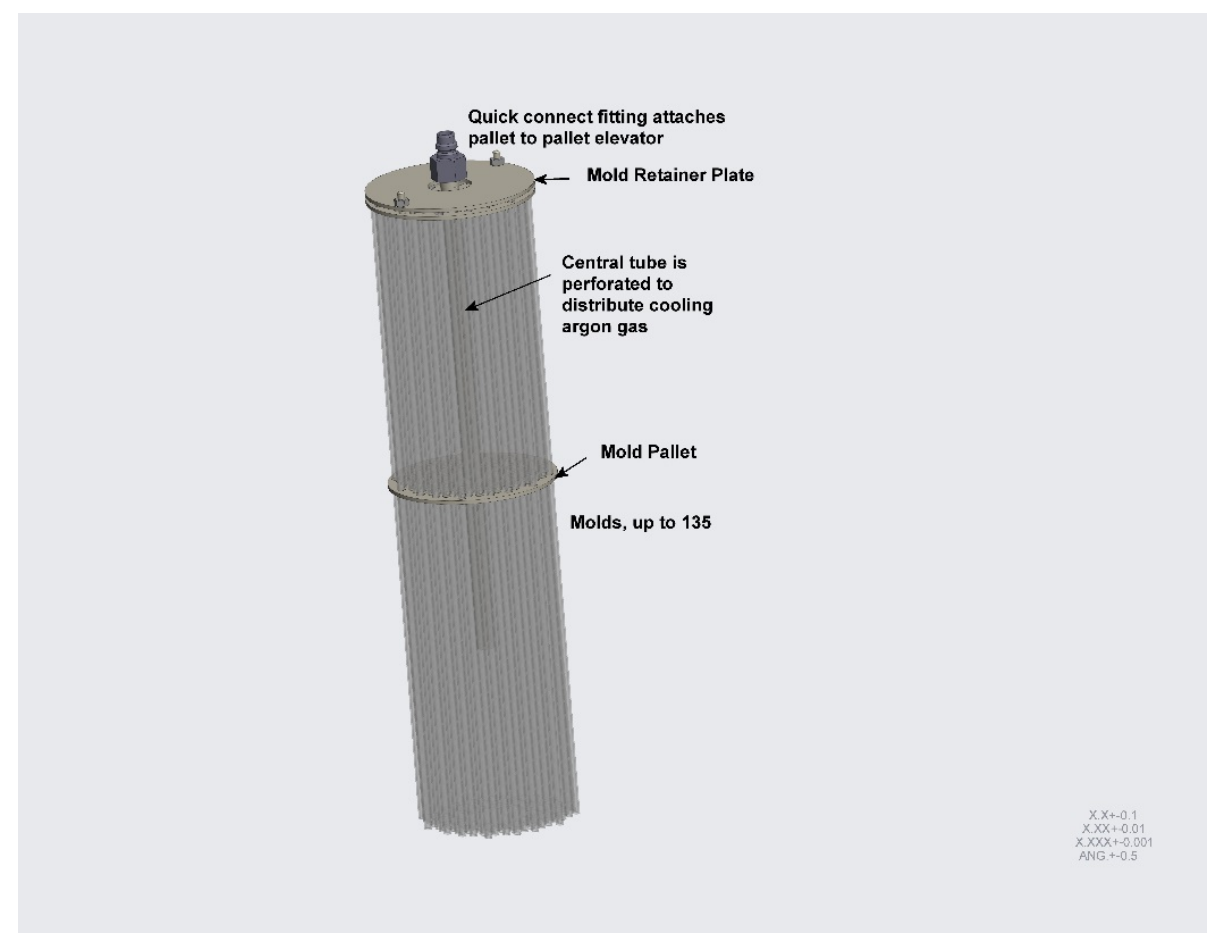

Figure 6. Mold Pallet.

The pallet frames are single-use, and are disposed of after each casting operation. By varying the pallet frame design, the furnace will be able to accommodate significant variations in mold size, number and length. This flexibility will be valuable in supporting development of the casting process and any variations identified in the final fuel slug design. 
Identifier: $\quad$ SPC-2954

Revision: $\quad 0$

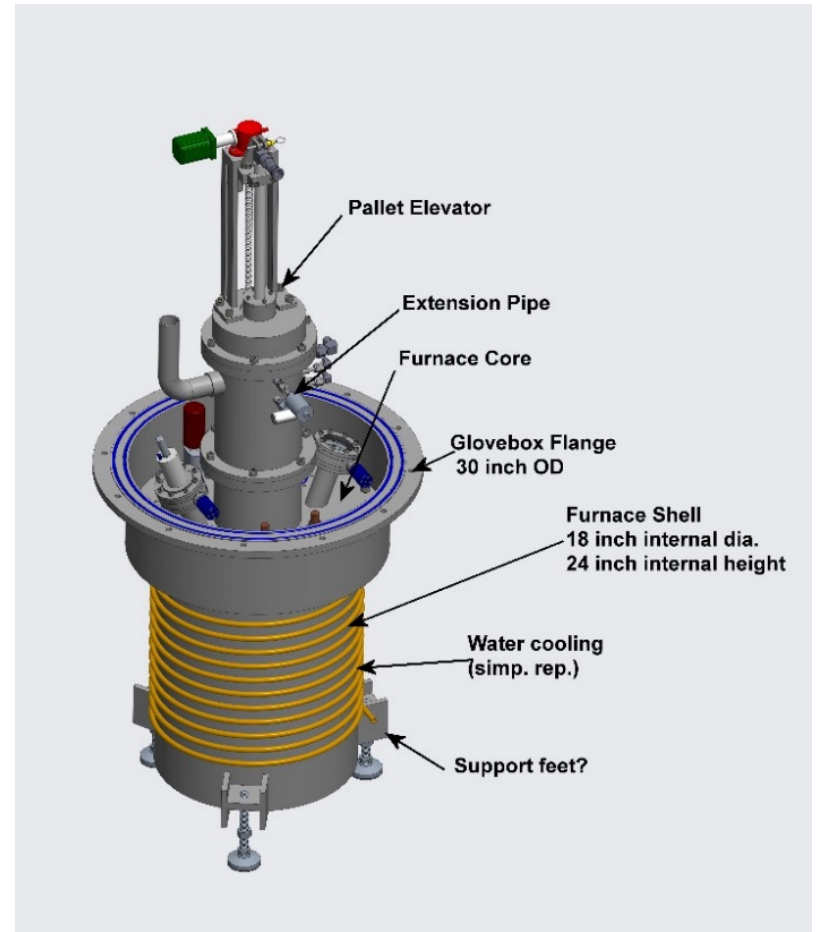

Figure 7. Casting Furnace.

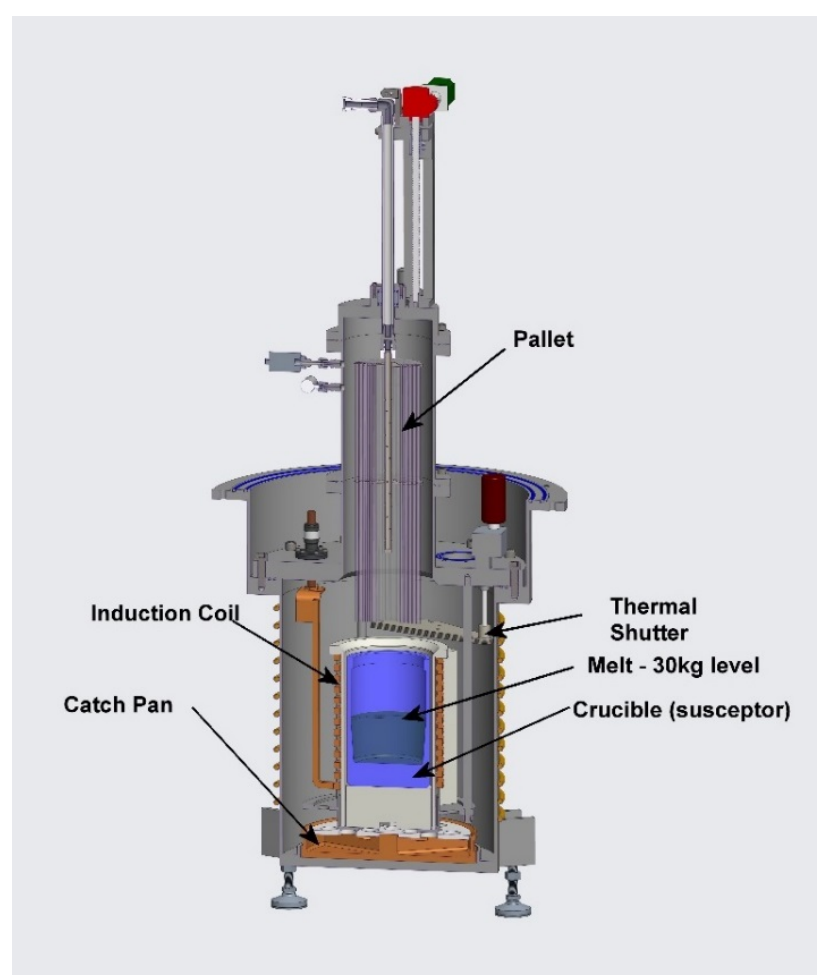

Figure 8. Casting Furnace Cut-Away. 


\begin{tabular}{l|lll|} 
URANIUM PROTOTYPE GLOVEBOX & Identifier: & SPC-2954 & \\
AND FURNACE DESIGN AND BUILD & Revision: & 0 & \\
& Effective Date: & $01 / 19 / 21$ & Page: B39 of B51 \\
\hline
\end{tabular}
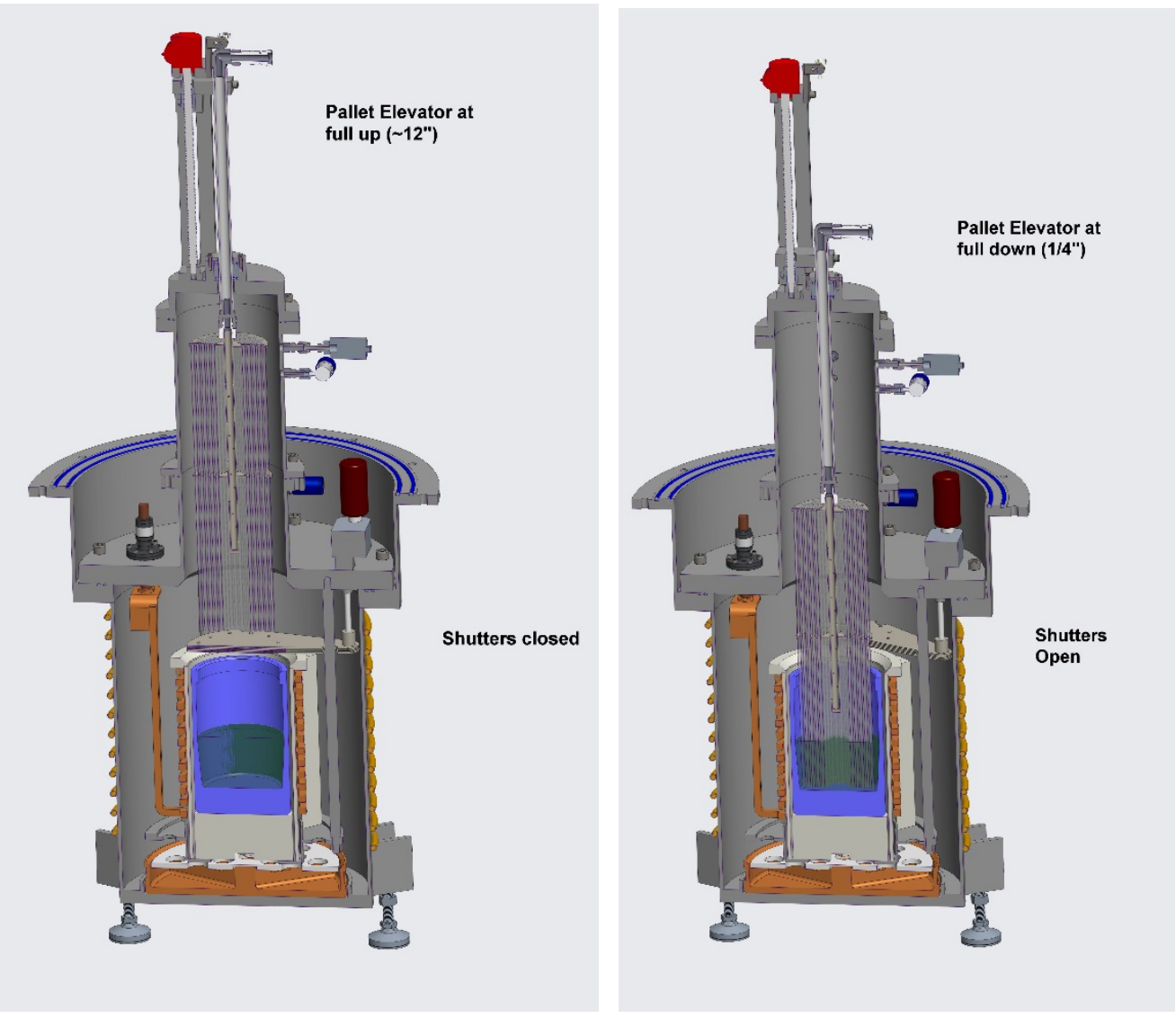

The conceptual furnace design was developed based on several casting furnaces previously used at INL for fabricating fuel elements of similar size and configuration.

There are some significant design limitations that arise from the need to install the furnace system into a glovebox:

1. The overall size of the glovebox flange is limited due to the need to be able to reach the centerline of the glovebox. In practice, the floor width should not exceed 38 inches. This is further reduced by the need for structural supports under the glovebox floor and the need for some clearance between the furnace flange and glovebox structure. A flange diameter of 30 inches is a practical maximum for a conventional glovebox configuration.

2. The furnace must be short enough to be installed under the glovebox floor, since it must be possible to install or remove the furnace without lifting the entire glovebox. The furnace must also clear the glovebox support structure during installation or removal. The conceptual design assumes a glovebox support structure height of 38 inches, which is relatively typical and provides acceptable ergonomics for work in the glovebox. Assuming 
that the structure will use 3 inch structural tubing, the furnace height must be reducible to less than 35 inches.

3. Installation of the pallet elevator and pallet requires raising the pallet elevator sufficiently for the pallet to clear the furnace using an internal hoist in the glovebox. The overhead space is limited due to the need to be able to transfer the glovebox shell into the facility through doors with a maximum height of less than 7 feet. Even using a conceptual low-profile hoist, this requirement necessitated incorporation of a well into the furnace shell design to provide sufficient overhead space.

4. It is highly desirable to design the furnace such that all mechanical seals are located inside the glovebox confinement boundary. Due to the nature of the materials being cast, even very small leaks outside of this confinement boundary present a hazard to the operating personnel in the vicinity of the system. Since the furnace internals (core) will be radiologically contaminated, the core is required to be removed into the glovebox for repair or refurbishment.

5. Crucible installation and removal will be through the elevator opening. Special tools will be needed for this operation. Visibility for this operation will be poor to non-existent.

The furnace shell bolts to a flange that is built into the floor of the glovebox. It provides both the confinement boundary and the pressure boundary for the process. The furnace's internal volume has been minimized to the extend practical, since this also allows smaller components to be used in the pressure/vacuum system that will be attached to the furnace.

Water cooling of the furnace shell is anticipated, since a water-cooled induction coil design cannot be used for this furnace. Based on INL fuel casting furnaces that use solid-coil designs, it is anticipated that significant heat will be radiated to the furnace shell to cool the coils. A set of copper tubing coils are shown on the conceptual design as a very simple representation of the potential need for cooling, since the actual extent and configuration of the cooling system will not be known until thermal analysis of a more complete design has been performed.

The seal on the glovebox flange is a double O-ring design. This seal is a critical one, as it is a part of the glovebox confinement boundary and therefore needs to meet the same seal performance requirements as the general glovebox boundary seals. A port would be provided that connects to the interstitial area between the O-rings to allow connection of a leak detection probe. This port would be plugged when not in use. 


\begin{tabular}{l|lll|} 
URANIUM PROTOTYPE GLOVEBOX & Identifier: & SPC-2954 & \\
AND FURNACE DESIGN AND BUILD & Revision: & 0 & \\
& Effective Date: & $01 / 19 / 21$ & Page: B41 of B51 \\
\hline
\end{tabular}

The "furnace core" is essentially the internal elements of the furnace, along with the upper flange that acts as the top pressure boundary for the furnace. This design allows the internal components to be withdrawn into the glovebox for maintenance or repair.

The extension pipe attached to the upper glovebox flange is removed during furnace installation/removal to reduce the height of the furnace and allow it to be moved into place below the glovebox. The overall height is necessary to provide room for the pallet and elevator to be installed with the bottom of the molds in the proper position above the crucible.

A copper catch pan is included, based on current practice with the other INL casting furnaces.

The "feet" on the furnace shell are intended primarily as a method to raise the shell into position under the glovebox to be bolted to the flange on the glovebox. If the glovebox shell is not sufficiently robust to support the weight of the furnaces, the feet may be used to support the furnaces. It is noted that, if used to support the glovebox, the feet may need to incorporate some compliance elements (springs or similar) to avoid applying excess stress to the glovebox floor due to thermal expansion of the shell during heating of the furnace. An alternative support leg design could also be used that would support the flange area directly (instead of being mounted on the furnace shell).

\subsection{Furnace Internal Components}

The furnace core consists of the furnace top closure flange, heating coils, coil insulation package and thermal shutters. The core encompasses essentially all the internal furnace components that would be expected to require periodic maintenance or replacement. 


\section{URANIUM PROTOTYPE GLOVEBOX AND FURNACE DESIGN AND BUILD}

Identifier:

Revision:

Effective Date: $01 / 19 / 21$

0
SPC-2954

Page: B42 of B51

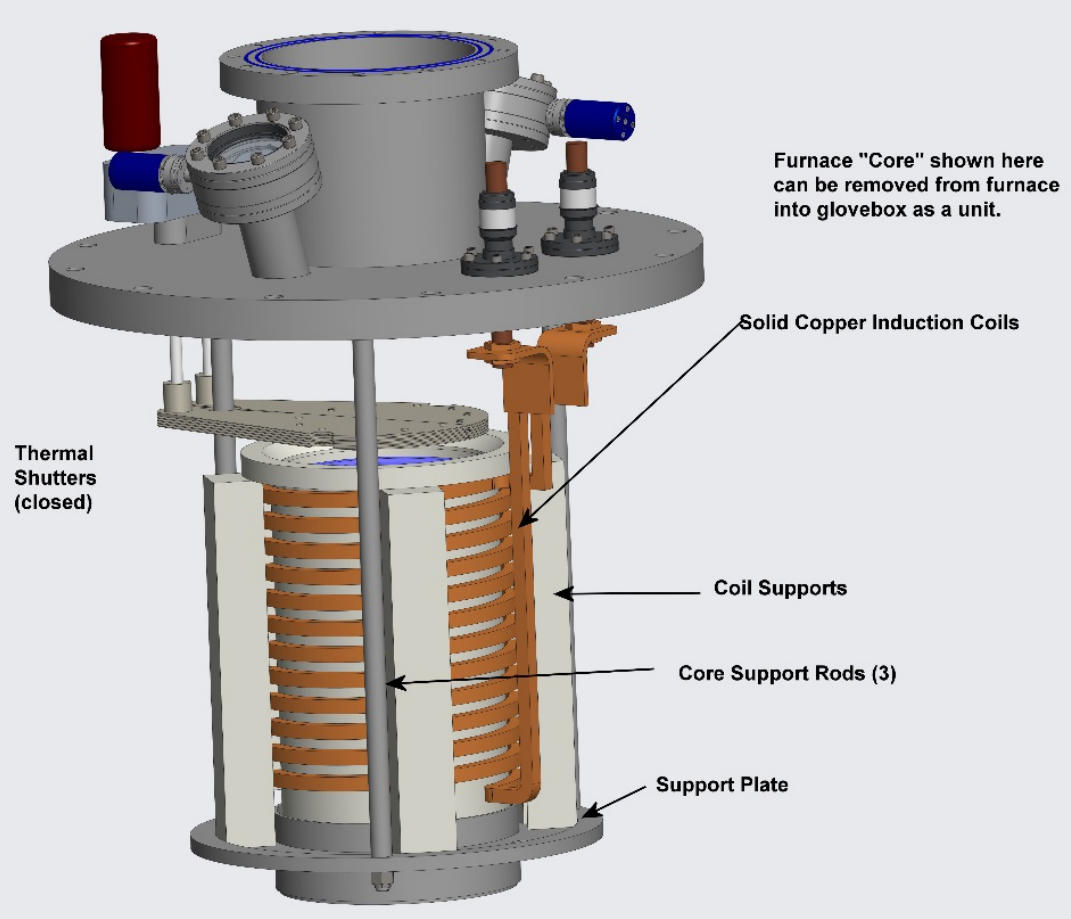

Figure 9. Furnace Core Assembly.

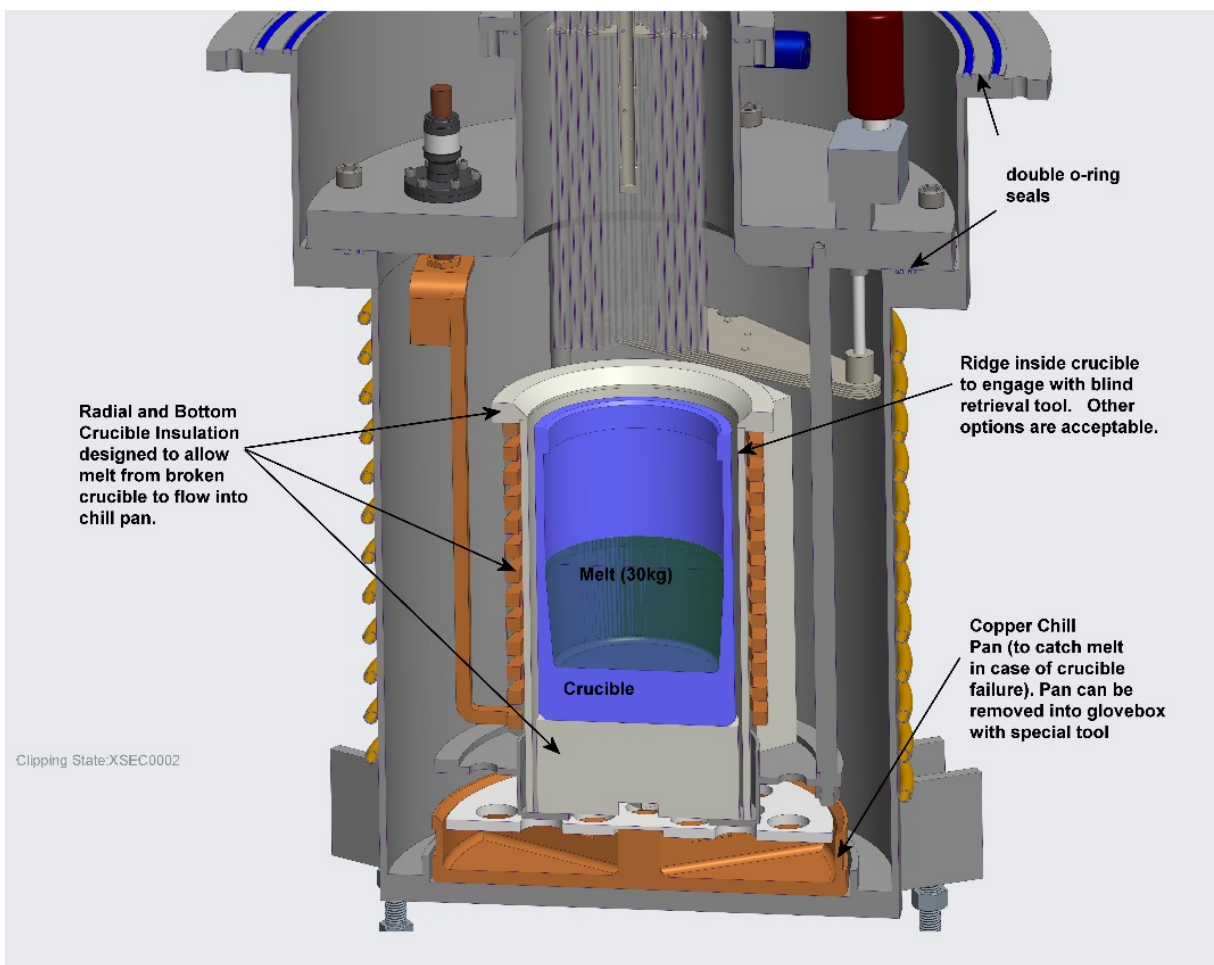

Figure 10. Cutaway of Furnace Vessel. 
The coil, crucible and insulation are suspended from the closure flange by support rods. The furnace core is intended to be removed into the glovebox to allow maintenance and replacement of the internal furnace components. With the exception of the closure flange, all core components are sized to allow them to be transferred through the 15 inch bagout port in the glovebox in case they require replacement.

The closure flange, and the flanges that attach the extension pipe and elevator to the furnace, and the gas system connection to the furnace all use the same type of double O-ring seal that is described for the flange that connects the furnace to the glovebox floor. In this case, there is much less concern with leakage, and use of the double O-ring design is not as important. This design is used here simply because it was used several previous INL furnaces and demonstrated good service in pressure-vacuum conditions and because the double O-ring is a "worst case" design with respect to the size of the sealing area. It is noted that many of the later INL furnace designs use single element seals, with no significant issues noted.

The closure flange is recessed approximately 8 inches below the glovebox flange. This configuration provides sufficient overhead room to allow the pallet elevator, with the pallet attached, to be raised clear of the furnace for loading and unloading.

The graphite crucible is based on an existing INL "20 kg" crucible, extended to provide additional room for up to $30 \mathrm{~kg}$ of material. The crucible both contains the molten fuel, and acts as an inductive susceptor for the induction heating process. It is noted that the actual maximum fuel loading is anticipated to be $22 \mathrm{~kg}$.

The induction coil is based on a previous INL design, modified to provide a different connection to the induction feedthroughs (the original connection used horizontal buss-bars). Additional turns were added to extend the coil to match the taller crucible. This previous furnace coil used $1 / 2$ inch square copper bar for this coil. No analysis of this coil design has been performed and the coil geometry should be considered as a general representation only.

Crucible insulation (base and radial) is based on the general geometry of the previous furnace, as are the ceramic coil supports. Radial insulation was a high alumina refractory. The base insulation was a high zirconia ceramic with three thin alumina or zirconia felt disks cast in place. Crucible supports and separators were fired "Lavite Lava Grade A" which appears to be an alumina silicate ceramic material. 
URANIUM PROTOTYPE GLOVEBOX AND FURNACE DESIGN AND BUILD

$\begin{array}{ll}\text { Identifier: } & \text { SPC-2954 } \\ \text { Revision: } & 0 \\ \text { Effective Date: } & 01 / 19 / 21\end{array}$

Page: B44 of B51

Conceptual power feedthroughs are a commercially available solid copper bar ceramic feedthrough with a $3 / 4$ inch diameter conductor rated for 800 amps current at $8000 \mathrm{Vdc}$ by MPF Products Inc. These were chosen based on the original power supply specifications for INL furnaces of similar capacity, which specified power inputs of $800 \mathrm{~V}, 3-10 \mathrm{kHz}, 25 \mathrm{~kW}$ and $600 \mathrm{~A}$.

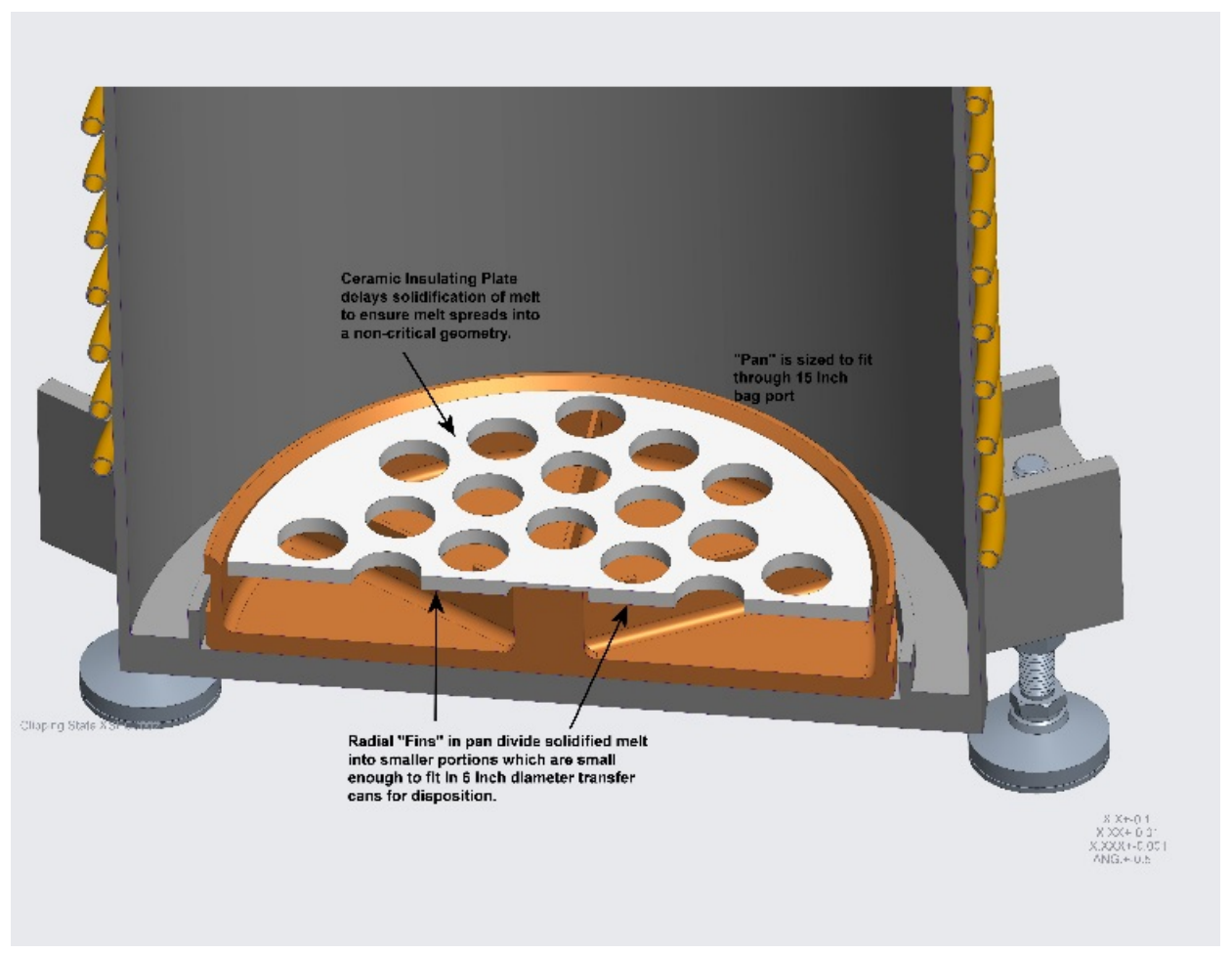

Figure 11. Catch Pan.

A copper catch pan is provided inside the furnace to protect the furnace shell in case of failure of the crucible while it contains molten fuel material. Ferrous alloys are subject to very rapid attack when in contact with uranium alloys at temperatures at or above $800^{\circ} \mathrm{C}$, due to formation of uranium-iron eutectic that is molten above this temperature. The copper pan will contain any molten fuel material that escapes the crucible. The fins are intended to divide the molten metal into smaller, more easily handled pieces. A ceramic insulating plate is intended to allow the metal to distribute into the pan instead of forming a large "lump" immediately under the source of leakage. This lump would be difficult to separate into portions that could be packaged for disposition.

It is noted that copper and uranium form a eutectic alloy with a solidus temperature of $950^{\circ} \mathrm{C}$. Because of this, the copper catch pan must be sufficiently massive to ensure that the melt cools below this temperature quickly to avoid eutectic penetration of the pan. Thermal analysis would be required to ensure the pan remains intact after collecting the melt. 
URANIUM PROTOTYPE GLOVEBOX AND FURNACE DESIGN AND BUILD

$\begin{array}{ll}\text { Identifier: } & \text { SPC-2954 } \\ \text { Revision: } & 0 \\ \text { Effective Date: } & 01 / 19 / 21\end{array}$

Page: B45 of B51

Thermal shutters are used to minimize radiant heating of the pallet and upper portions of the furnace during heating operations. These are configured in a "butterfly" arrangement.
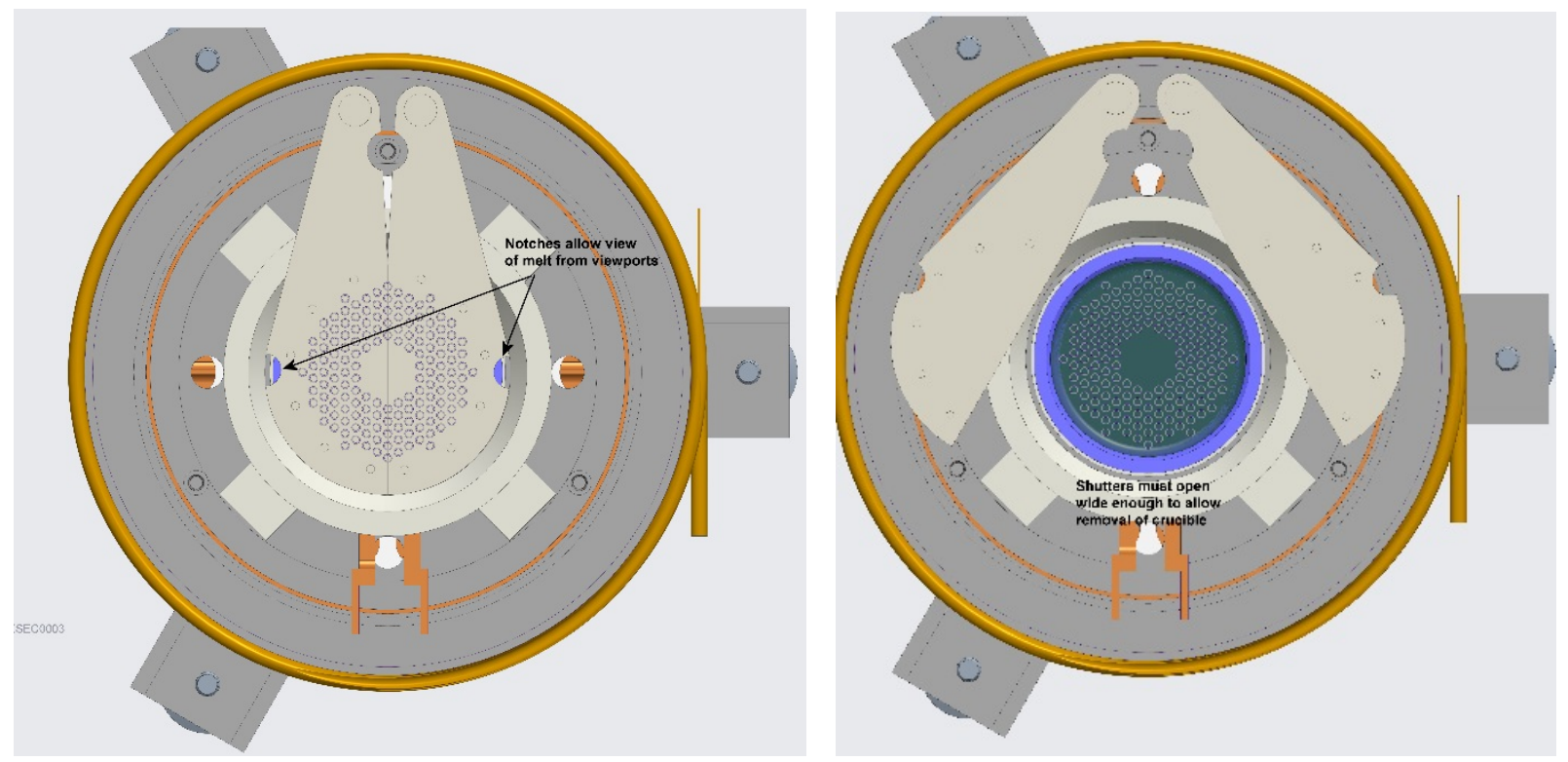

The butterfly design allows use of a smaller furnaces shell than a single round shield. While the operating mechanism has not been detailed, it is expected that it would incorporate a set of sector gears that would synchronize the shutter operation. A small actuator would be connected to one shaft to drive the shutters open and shut. The actuator should be removable from the shafts to allow for repair or replacement without removing the furnace core from the furnace.

\subsection{Pallet Elevator}

The pallet elevator is mounted to the extension pipe that is in turn mounted to the furnace flange. 
Identifier: $\quad$ SPC-2954

Revision: $\quad 0$

Effective Date: $01 / 19 / 21$

Page: B46 of B51

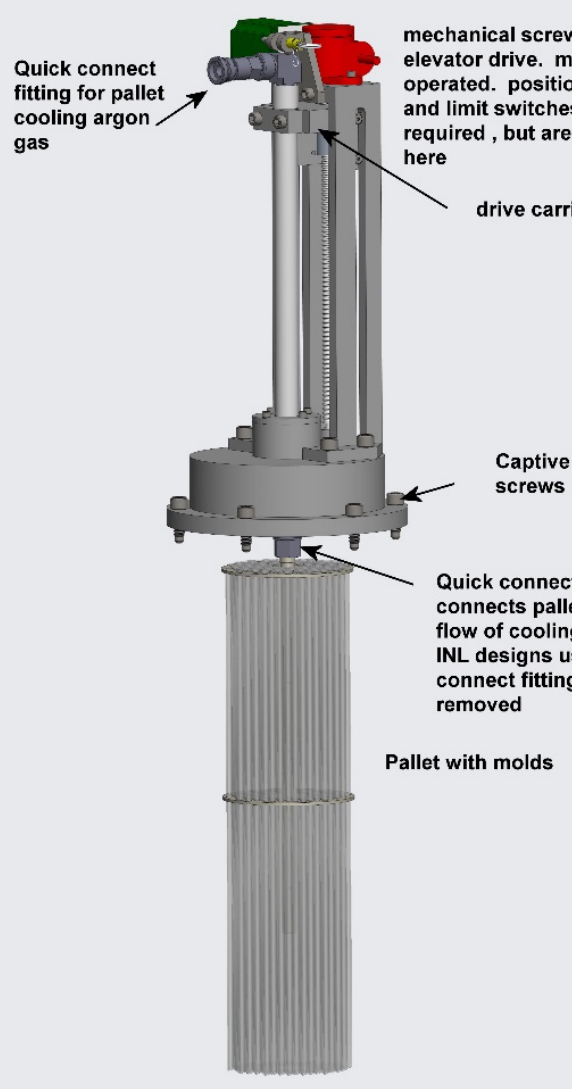

Figure 12. Pallet Elevator.

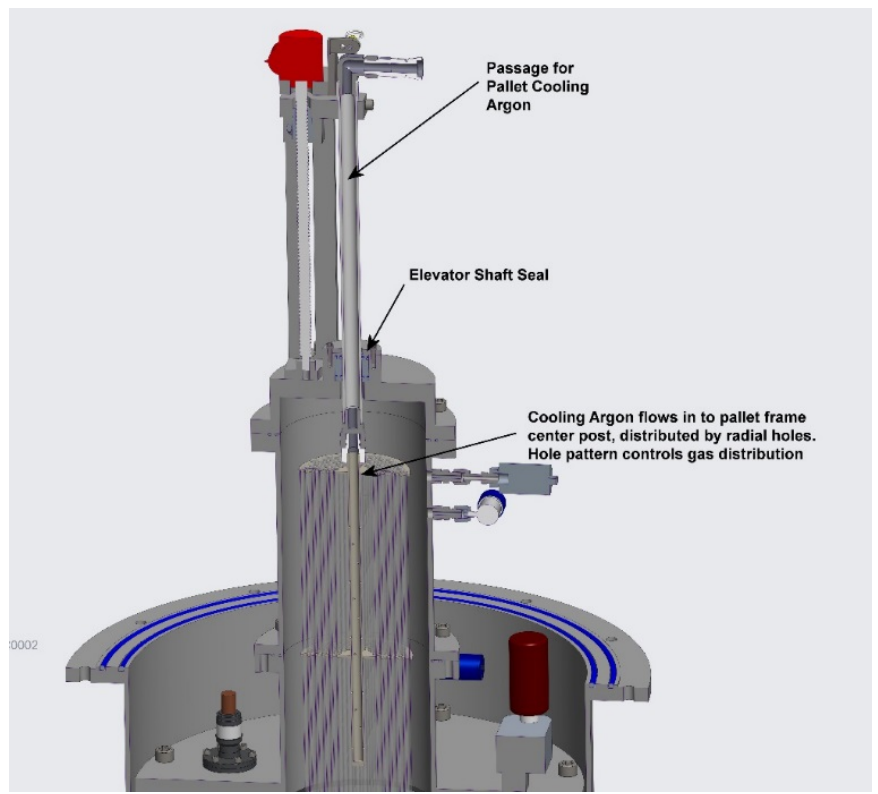

Figure 13. Cutaway, Upper Furnace. 
URANIUM PROTOTYPE GLOVEBOX AND FURNACE DESIGN AND BUILD

$\begin{array}{ll}\text { Identifier: } & \text { SPC-2954 } \\ \text { Revision: } & 0 \\ \text { Effective Date: } & 01 / 19 / 21\end{array}$

Page: B47 of B51

The pallet elevator system uses a central pipe that passes through a dynamic seal and connects to the mold pallet. This pipe provides a passage for pressurized argon gas that is used to cool the molds after casting. The central pipe is connected to a drive mechanism that raises and lowers the pallet during the casting process. The conceptual design uses a mechanical acme screw drive mechanism. This system would be fitted with limit switches and a position indicating system that are not shown.

\subsection{Additional External Furnace Details}

The furnace design incorporates two windows that allow viewing of the crucible and contents. The windows will also accommodate installation of pyrometers and/or video cameras for determining melt temperature and for investigating melt behavior.

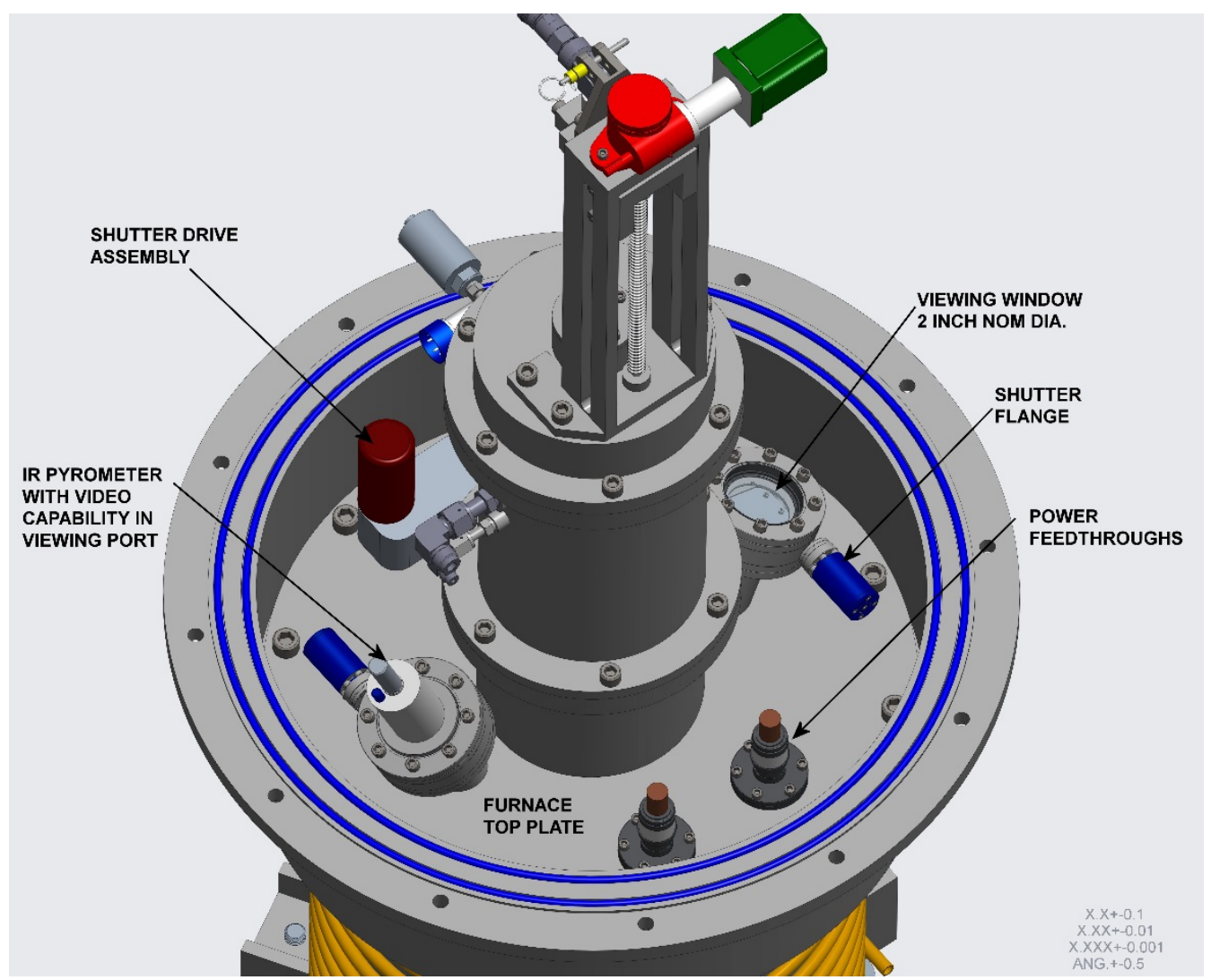

Figure 14. Top Configuration.

The windows are fitted with shutters to prevent deposition of fumes and other contaminants on the windows during operation, and to reduce heating of the windows when not in use. Windows of 2 inch nominal diameter are shown in this conceptual design. 
URANIUM PROTOTYPE GLOVEBOX AND FURNACE DESIGN AND BUILD

$\begin{array}{ll}\text { Identifier: } & \text { SPC-2954 } \\ \text { Revision: } & 0 \\ \text { Effective Date: } & 01 / 19 / 21\end{array}$

Page: B48 of B51

The connections for the pressure system are on the furnace flange. During development of the glovebox design, it was identified that a single power penetration location should be used for delivering power to both furnaces in order to maximize useable space in the glovebox. To accommodate this configuration, the power penetrations on both gloveboxes should face toward each other.

\subsection{Furnace System in Glovebox}

Two furnaces are located in the glovebox. A vacuum pump is installed under the glovebox and will be used to evacuate the furnaces when required by the casting injection process.

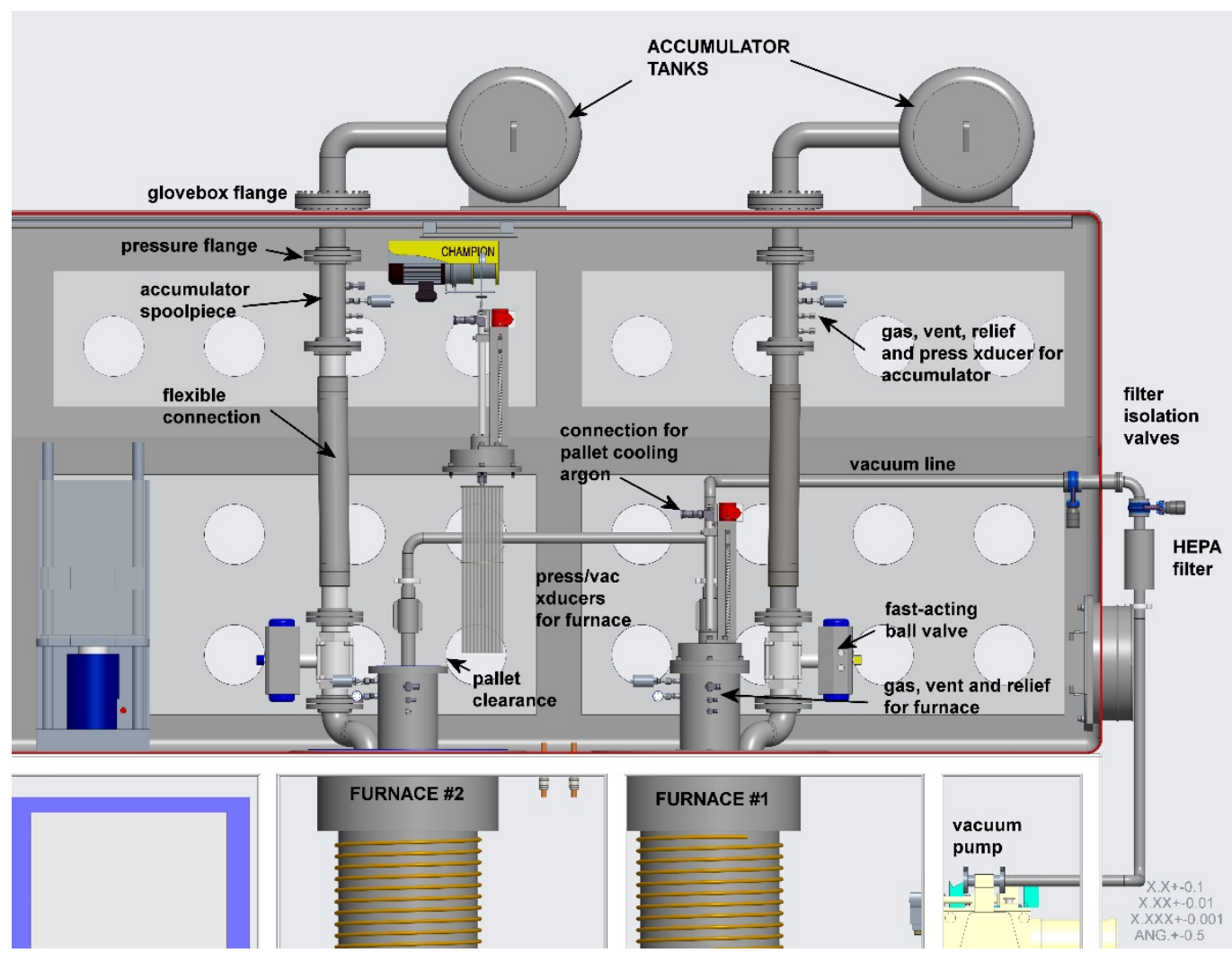

Figure 15. Casting System Arrangement.

The vacuum system consists of a single vacuum pump that is connected to both furnaces. Each furnace is provided with a vacuum solenoid valve to isolate the vacuum system when it is not needed for that furnace, and to avoid exposing the vacuum system to significant positive pressure. Furnace power and controls are shown below the glovebox. This location is desirable to reduce the total facility footprint, but it may not ultimately be practical. It is possible that this location could be used for the power matching capacitor bank system for the furnaces, with other portions of the power supply located remotely if required. 


\section{URANIUM PROTOTYPE GLOVEBOX AND FURNACE DESIGN AND BUILD}

Identifier: $\quad$ SPC-2954

Revision: $\quad 0$

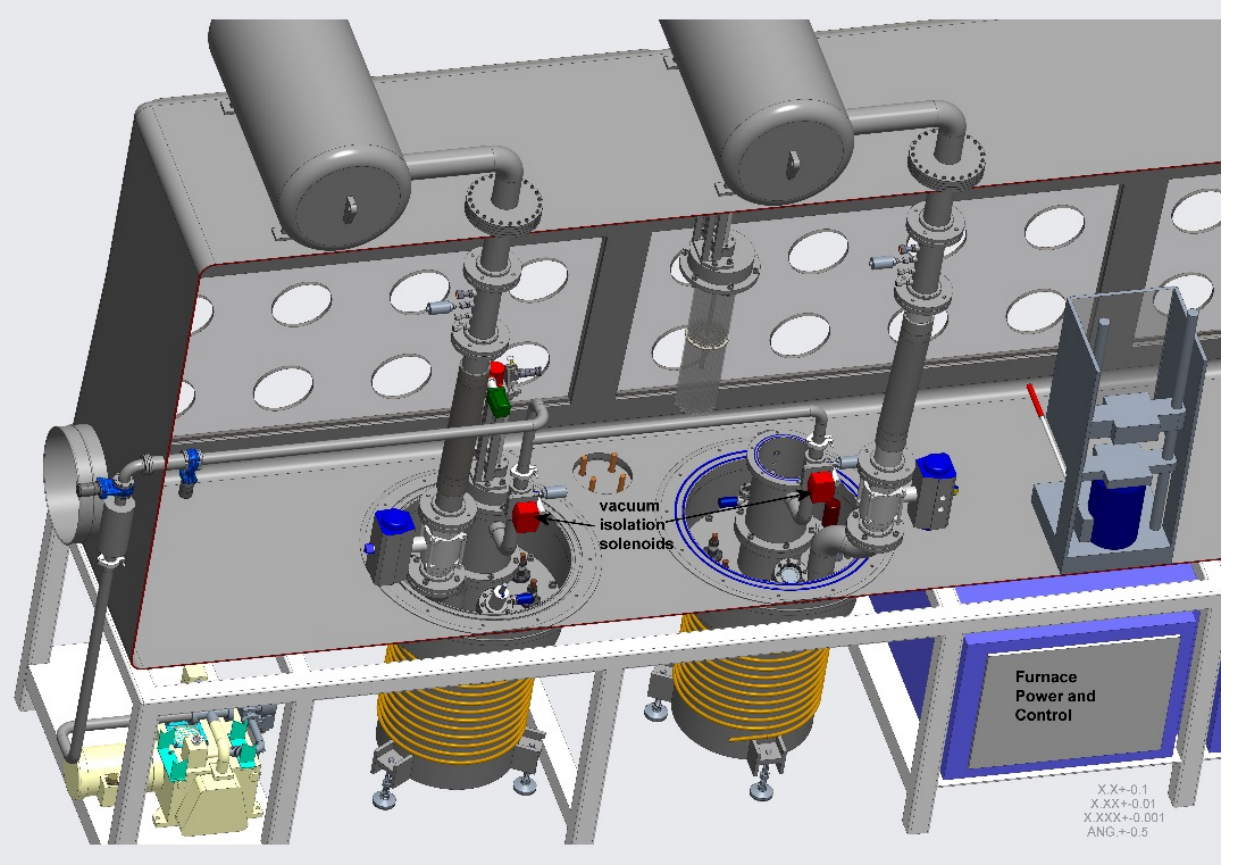

To quickly pressurize the casting furnaces during the injection casting operation, each casting furnace is provided with an argon accumulator tank. Once the furnace contents are melted and mixed, the furnace is evacuated. The molds are dipped into the molten alloy and the accumulator (which has been pressurized with argon to a pre-determined pressure) is connected to the furnace by opening a quick-acting ball valve. The furnace and accumulator equalize pressures at the desired casting pressure within one second.

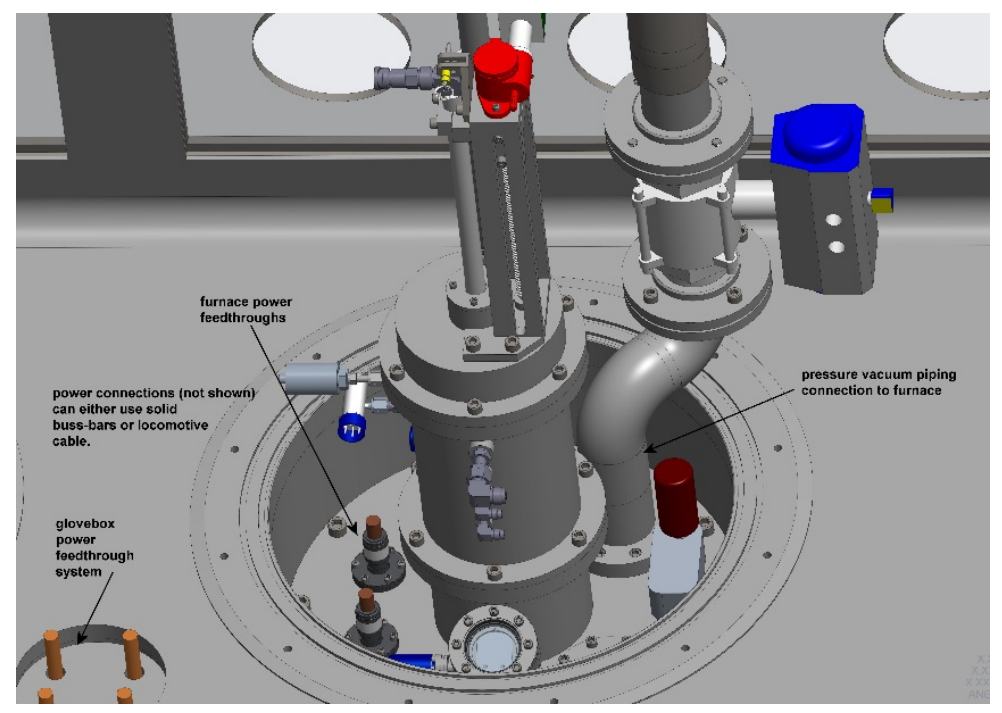

Figure 16. "Front" side overhead view of furnace.

Appendix B 
URANIUM PROTOTYPE GLOVEBOX AND FURNACE DESIGN AND BUILD

$\begin{array}{ll}\text { Identifier: } & \text { SPC-2954 } \\ \text { Revision: } & 0 \\ \text { Effective Date: } & 01 / 19 / 21\end{array}$

Page: B50 of B51

The piping systems inside the glovebox are offset toward the back side (in the above view) to allow clearance for use of the glovebox hoist in loading and unloading the furnace, as well as for maintenance operations such as furnace core removal. Also shown in the above view is the clearance provided between the pallet and top of the furnace (on the left-hand furnace).

The pressure piping and fast acting ball valve are connected directly to the upper flange of the furnace. To maximize available working floor space in the glovebox, power connections for both furnaces are lead to a single power feedthrough on the glovebox floor.

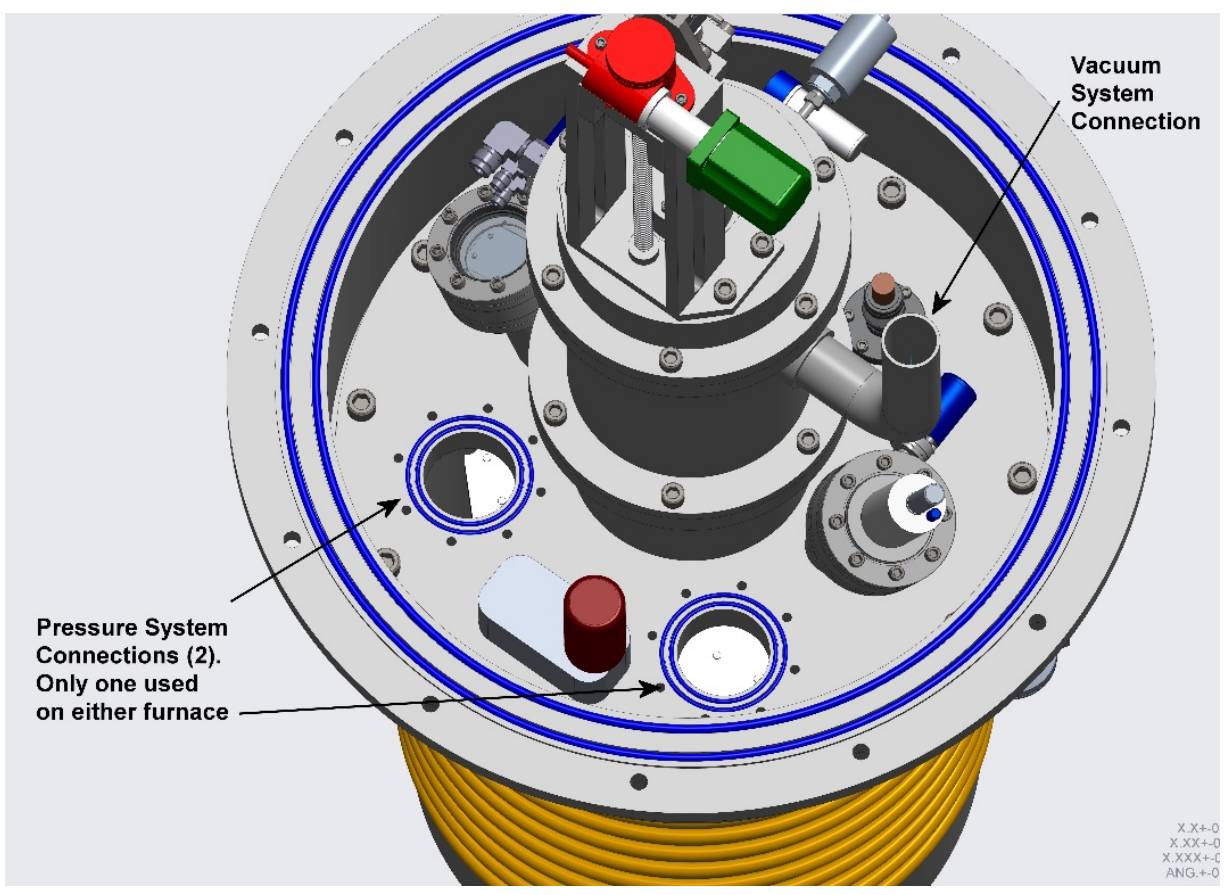

Figure 17. Main Pressure and Vacuum Connections.

Due to the use of a single electrical penetration, the glovebox cores had to be installed in a mirrored configuration so that the electrical furnace feedthroughs were closer to the glovebox penetration. To accommodate the need to offset the pressure system piping for pallet handling without requiring that each furnace be completely unique, two pressure connections are provided. The un-used penetration on each furnace will be closed by a blind flange. For the vacuum system, the penetrations were placed on the extension pipe that can be installed in either orientation.

Installation of the pressure system to the extension pipe was considered, but this would expose the relatively hot molds directly to the cold argon flow during injection molding. This would almost certainly result in mold failures and casting failures due to overcooling of molds, and was therefore rejected. 


\begin{tabular}{l|lll|} 
URANIUM PROTOTYPE GLOVEBOX & Identifier: & SPC-2954 & \\
AND FURNACE DESIGN AND BUILD & Revision: & 0 & \\
& Effective Date: & $01 / 19 / 21$ & Page: B51 of B51 \\
\hline
\end{tabular}

\subsection{Design for Installation and Removal}

While installation or removal of an entire furnace would be a very unusual event, it is likely to be needed at some point over the lifetime of the system.

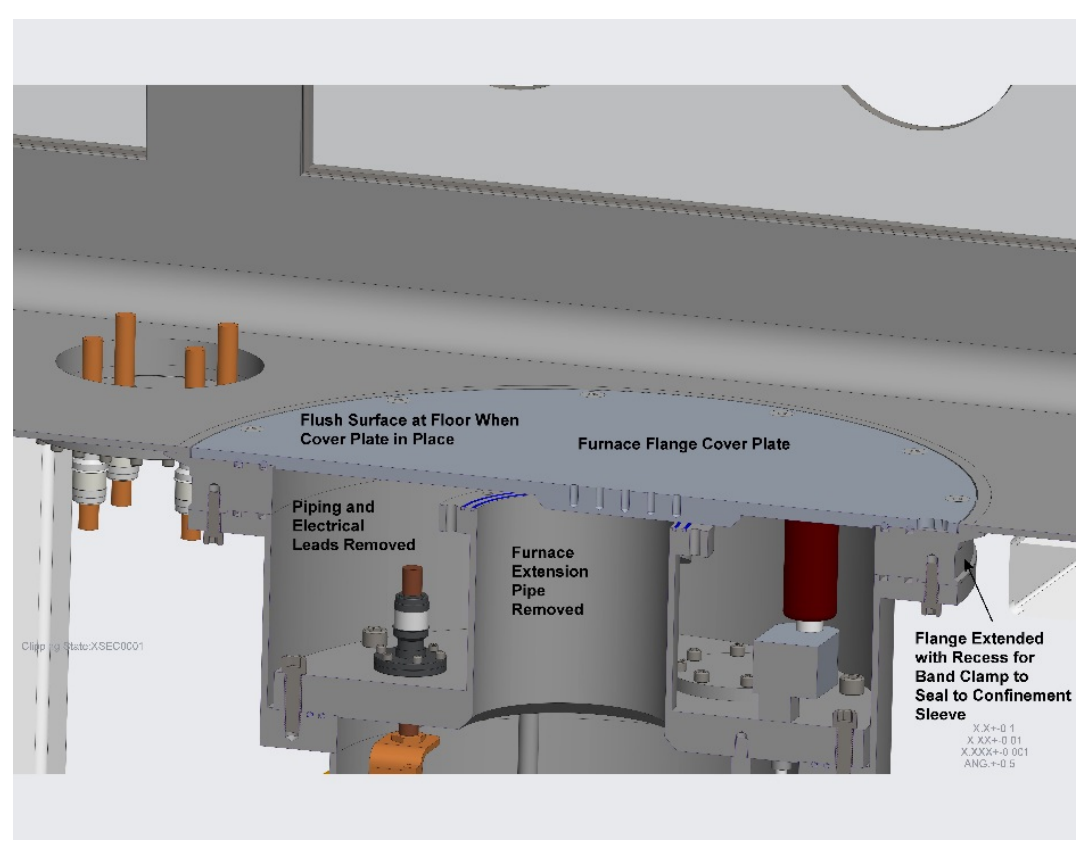

Figure 18. Furnace Installation/Removal.

To accommodate total removal of the furnace, it is designed to be short enough to be removed from the glovebox with the furnace core installed. To ensure a robust confinement boundary while the furnace is not installed, a flange cover is provided, and would be kept inside the glovebox when not in use. This would also allow the system to be operated for an extended period with only a single installed furnace. The glovebox flange is configured to allow attachment of a radiological sleeve that would be part of an overall confinement system to be developed by INL for use in the eventuality that the furnace would need to be installed or removed. The furnace cover is flush with the glovebox floor when installed to allow it to be used without restriction as part of the working surface of the glovebox. 